Міністерство освіти і науки України

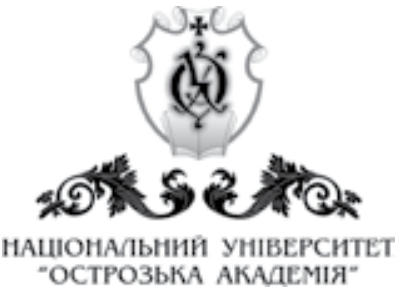

Факультет романо-германських мов

Національного університету «Острозька академія»

Кафедра міжнародної мовної комунікачії

Національного університету «Острозька академія»

\title{
ENGLISH \\ FOR SPECIFIC PURPOSES
}

\author{
Випуск 5
}

Острог

Видавництво Національного університету «Острозька академія» 


$$
3-41
$$

Рекомендовано до друку радою факультету романно-германських мов Наиіонального університету "Острозька академія» (протокол № 8 від 8 травня 2018 року)

\section{Редакційна колегія:}

Шевчук Дмитро Михайлович - проректор з науково-педагогічної роботи Національного університету «Острозька академія»;

Ковальчук Інна В'ячеславівна - кандидат психологічних наук, доцент, декан факультету романо-германських мов Національного університету «Острозька академія»;

Крайчинська Галина Вацлавівна - кандидат філологічних наук, доцент, завідувач кафедри міжнародної мовної комунікації Національного університету «Острозька академія».

\section{Технічний секретар:}

Микитюк Тетяна Сергіївна - старший лаборант кафедри міжнародної мовної комунікації Національного університету «Острозька академія».

\section{Рецензенти:}

Тищенко Олег Володимирович, доктор філологічних наук, професор;

Жуковський Василь Миколайович, доктор педагогічних наук, професор.

English for Specific Purposes : збірник наукових тез / Ред. кол. Д. М. Шевчук, І. В. Ковальчук, Г. В. Крайчинська. - Острог : Видавництво Національного університету «Острозька академія», 2018. - Випуск 5. -168 с

ISBN 955-7631-70-2

У збірнику вміщено тези, присвячені проблемі викладання професійної англійської у вищих навчальних закладах. Тези стосуються таких основних тем: контроль рівня володіння англійською мовою як складова оптимізації навчання професійної англійської; професійна англійська для немовних спеціальностей; інтерактивні методи навчання професійної англійської та інформаційні технології в освіті; країнознавство у навчанні професійної англійської; комунікативний підхід при викладанні професійної англійської..

$$
\text { Адреса редколегії: }
$$

35800, Украӥна, Рівненська область, м. Острог, вул. Семінарська, 2.

\section{УДК 81.111}

\section{ББК 81.2}

(C) Видавництво Націоанльного університет «Острозька академія», 201
Блоха Мирослава

РОЛЬ МЕТАФОРИ У СТВОРЕННІ ПРАГМАТИЧНОГО ЕФЕКТУ

(на прикладі роману Р. Аспріна «Ще один дивовижний міф»)

Бобер Анастасія

ВИКОРИСТАННЯ КОМУНІКАТИВНОГО ПІДХОДУ

ДЛЯ ФОРМУВАННЯ ІНШОМОВНОЇ ПРОДУКТИВНОї

КОМПЕТЕНТНОСТI

\section{Бобков Вадим}

СТЕРЕОТИПНЕ СПРИЙНЯТТЯ МЕТРОЛОГІЧНОЇ ФРАЗЕОЛОГЇ̈

(англ., нім., пол., укр. мови)

\section{Божченко Владислав}

ПОРІВНЯЛЬНО-ІСТОРИЧНИЙ МЕТОД КЛАСИФІКАЦІЇ МОВ СВІТУ 20

\section{Брожик Ольга}

СИНТАКСИЧНІ ЗАСОБИ ЕКСПРЕСИВНОСТ

В АМЕРИКАНСЬКІЙ ОНЛАЙН-ГАЗЕТІ «ТНЕ ТIMЕS»

Войціховський Ілля

НАЦІОНАЛЬНО-КУЛЬТУРНІ ОСОБЛИВОСТ

АНГЛОМОВНОЇ ЕЛЕКТРОННОЇ КОМУНІКАЦЇ

\section{Воробей Вімалій}

ЛЕКСИЧНІ І СТИЛІСТИЧНІ ОСОБЛИВОСТІ

ПУБЛШЦИСТИЧНОГО СТИЛЮ

Гаталяк Марта

БЛОГОСФЕРА ТА ОСОБЛИВОСТІ, ЕТАПИ РОЗВИТКУ БЛОГУ

\section{Герасимчук Валентина}

МОВНИЙ ПОРТРЕТ ЧАРЛІ ГОРДОНА У ТВОРІ

«FLOWERS FOR ALGERNON» BY DANIEL KEYES

\section{Іванішина Наталія}

ВЕРБАЛІЗАЦІЯ ВВІЧЛИВОСТІ У МОВАХ ОРИГІНАЛУ

ТА ПЕРЕКЛАДУ

Іванова Ольга

ЛЕКСИКО-СЕМАНТИЧНИЙ АСПЕКТ КЛАСИФІКАЦІЇ МЕТАФОР 
Кобильчук Вадим

КІНОФІЛЬМ ЯК ОКРЕМИЙ ВИД ДИСКУРСУ

\section{Козловська Ольга}

ЕТИКЕТ У ВІРТУАЛЬНІЙ АНГЛОМОВНІЙ КОМУНІКАЦІ 73

\section{Крайчинська Галина}

РОЗВИТОК КОМУНІКАТИВНИХ НАВИЧОК СТУДЕНТІВ НЕМОВНИХ СПЕЦІАЛЬНОСТЕЙ (на основі професійно спрямованих комплексів з англійської мови видавництв Cambridge, Longman,

Oxford University press)

\section{Курілович Ольга}

АНГЛІЙСЬКА МОВА ЯК ГОЛОВНИЙ ЧИННИК ВПЛИВУ

НА СЛОВОТВІР СУЧАСНОЇ КИТАЙСЬКОЇ ІНТЕРНЕТ-ЛЕКСИКИ 82

\section{Максимчук Ірина}

МОВНІ ЗАСОБИ ВИРАЖЕННЯ КОНЦЕПТУ КОХАННЯ

В РОМАНІ ЕЛІЗАБЕТ ГІЛБЕРТ «ЇСТИ. МОЛИТИСЯ. КОХАТИ.» .....

Мельник Анна

ЛЕКСИЧНА ХАРАКТЕРИСТИКА МОЛОДІЖНОГО СЛЕНГУ НА ПРИКЛАДІ ПОВІДОМЛЕНЬ ЕАСЕВООК

\section{Мирончук Ірина}

ОСОБЛИВОСТІ ВИКОРИСТАННЯ СТИЛІСТИЧНИХ ЗАСОБІВ

НА ПОЗНАЧЕННЯ ОБРАЗІВ ЗЛА (на прикладі кінотрилогіі

«Володар кілець»)

\section{Місюк Ярослав}

АНГЛІЙСЬКА СЛЕНГОВА ЛЕКСИКА ТА НЕТИКЕТ

ЯК ЧИННИКИ ЕФЕКТИВНОÏ ВІРТУАЛЬНОЇ КОМУНІКАЦІІ

\section{Новікова Ірина}

ІНШОМОВНІ ЗАПОЗИЧЕННЯ В АНГЛІЙСЬКІЙ ПРОЗІ

(на прикладі повісті Річарда Прескотта «Офіційно мертвий»)

\section{Новоселецька Світлана, Шапран Наталія}

МЕТОДИКИ ФОРМУВАННЯ НАВИЧОК УСНОГО МОВЛЕННЯ

НА ЗАНЯТТЯХ 3 АНГЛІЙСЬКОЇ МОВИ УЧНІВ

ПОЧАТКОВОЇ ШКОЛИ

\section{Радчук Олена}

ФРАЗЕОЛОГІЧНІ ОДИНИЦІ ІЗ КОМПОНЕНТОМ-ЗООНІМОМ

СТРУКТУРНО-СЕМАНТИЧНИЙ АСПЕКТ

(на прикладі німецької та англійської мов)

\section{Савіцька Аліна}

МІФІЧНІ СТВОРІННЯ У ФОЛЬКЛОР АНГЛОМОВНИХ КРАЇН

\section{Соломчук Ольга}

МЕТАФОРА I МЕТОНІМІЯ ЯК ЗАСОБИ ТВОРЕННЯ ОБРАЗНОСТІ

\section{Тилько Анастасія}

ХАРАКТЕРИСТИКА ЛЕКСИЧНИХ ЗАСОБІВ НА ПОЗНАЧЕННЯ НЕГАТИВНИХ ТА ПОЗИТИВНИХ ЕМОЦІЙ

(на матеріалі книги Джона Гріна «Паперові міста»)

\section{Трофименко Анастасія}

РОЗВИТОК МІЖКУЛЬТУРНОЇ КОМУНІКАТИВНОЇ КОМПЕТЕНЦЇ В КОНТЕКСТІ ГЛОБАЛІЗАЦІЇ

Ціось Ангеліна

ГЕНЕАЛОГІЧНЕ ДЕРЕВО ЯК СЮЖЕТОТВОРЧИЙ ЕЛЕМЕНТ У ЦИКЛ РОМАНІВ «ПІСНЯ ЛЬОДУ ТА ПОЛУМ'Я» ДЖОРДЖА МАРТІНА

\section{ВІДОМОСТІ ПРО АВТОРІВ}


УДК 81’324:82.09

Блоха Мирослава

(м. Острог, Україна)

Національний університет «Острозька академія»

\section{РОЛЬ МЕТАФОРИ У СТВОРЕННІ ПРАГМАТИЧНОГО ЕФЕКТУ} (на прикладі роману Р. Аспріна «Ще один дивовижний міф»)

У тезах проводиться аналіз використання метафор та метафоричних конструкиій у контексті досягнення прагматичного ефекту на читача.

Ключові слова: прагматика, метафора, прагматичний ефект.

В тезисах анализируется употребление метафор и метафорических конструкиий в контексте достижения прагматического эффекта на читателя.

Ключевые слова: прагматика, метафора, прагматический эффект.

This researh analyzes the use of metaphors and metaphorical constructions that create pragmatic effect on a reader.

Key words: pragmatics, metaphor, pragmatic effect.

Постановка проблеми полягає в суттєвому зростанні інтересу до дослідження прагматики тексту, аналіз з точки зору якої багато науковців раніше помилково вважали некомпетентним. Напрям лінгвістичної прагматики, який в Україні почав розвиватись в 70x pр., помалу розширював досить вузько спеціалізовану проблематику, і зараз по праву вважається одним з найперспективніших в сучасній світовій лінгвістиці. Аналіз прагматичного ефекту тексту залишається актуальною темою для досліджень.

Аналіз останніх досліджень: різні аспекти прагматики вивчались у працях таких лінгвістів, як Г. Гріц, Дж. Серль, Ч. Морріс. Дослідженню сучасної прагматики присвятили свої праці Н. Хомський, Ю. Хабермас, Дж. Ліч, Дж. Серль, Т. Коен, Дж. Катц і

(C) Блоха Мирослава, 2018
Дж. Остін. Сучасні дослідження в цій сфері в Україні проводили Л. Безугла, Ф. Бацевич, Н. Баландіна та інші.

Мета тез: дослідити значення використання метафори у створенні прагматичного ефекту на прикладі роману Р. Аспріна «Ще один дивовижний міф».

Для реалізації поставленої мети передбачено виконання таких завдань:

- прослідкувати історію прагматики;

- визначити особливості прагматичного ефекту різних функціональних стилів;

- дослідити прагматичну функцію метафори на прикладі роману.

Одним $з$ підходів до вивчення метафори є зосередження на прагматичному посилі, тобто, з усіх іiі функцій найбільша увага приділяється значенню, яке виокремлює реципієнт. Всупереч тому що деякі лінгвісти піддають сумніву доцільність такого методу, прагматичний потенціал тексту стає все більш популярним предметом для досліджень.

Припущення, що метафора - це відхилення від буквального значення, походить від «Поетики» Аристотеля. Ця позиція була широко розвинена в рамках так званої стандартної прагматичної моделі, пов'язана перш за все з філософами Гріце $(1975,1978)$ і Сірлом (1979). Гріц вважав, що метафора порушує один із кооперативних принципів регуляції спілкування «Не кажи, що ти вважаєш помилковим», i, таким чином, має дефективну природу порівняно $з$ прямим значенням. Згідно з його судженням, слухач спирається на набір логічних висновків щоб зрозуміти метафору, смисл якої відокремлений від лінгвістичного значення. Тим самим, порівнюючи з інтерпретацією прямого сенсу, розуміння метафори є значно складнішим процесом, адже воно включає:

- розуміння прямого сенсу повідомлення;

- осмислення прямого сенсу метафори як дефективного;

- пошук іншого тлумачення.

Дослідження прагматики має філософські витоки і, в цілому, $\epsilon$ спробою розрізнити формальну мову та форму іï використання. Перші згадки про прагматичний потенціал тексту можна відсте- 
жити у теорії Чарльза Моріса, який бачив прагматику як зв’язок знаків і користувача, що є протилежним до синтаксису (відношення одних знаків до інших) та семантики (відношення знаків до того, що вони позначають). Розвиток цієї сфери лінгвістики припадає на 1970, адже саме тоді була розвинена концепція мовної філософії. Важливою стала заява Гербера Пола Гріца, який припустив, що різниця між формальною мовою та вживаною може бути зменшена при розумінні, що лінгвістичне значення значення надане мовцем не є тотожними. При цьому він представив нові концептуальні інструменти, зокрема, поняття «імлікатура», що стало основою для сучасної прагматичної теорії.

В той час як багато лінгвістів та психологів вважають прагматичний підхід до вивчення метафори некомпетентним, немає доказів тому, що розуміння метафори може обмежуватись лиш комунікаційним аспектом. 3 іншого боку, нещодавні праці в сфері лінгвістики демонструють обчислювальні моделі в прагматичному обмірковуванні, де мовець і реципієнт аналізують прагматичний ефект діалогу для кращого та яснішого спілкування.

Сьогодні метафора реалізується в текстах різних жанрів, стилів та різноманітної направленості. Найчастіше метафора зустрічається, звичайно, у художньому, публіцистичному та розмовно-побутовому стилях, хоча присутня у невеликій кількості й у науковому та офіційно-діловому стилях, де має свою специфіку, свої особливості налагодження зв'язку з реципієнтом.

Отож, у проаналізованому романі Р. Аспріна «Another Fine Myth» представлені всі основні види метафор, хоча деякі з них не досить широко реалізовані. В першу чергу, це пояснюється авторським стилем, який не завжди вимагає поетичності опису та образності, але потребує «живих, незатертих» діалогів. Здебільшого, метафора виражена як метафора-текст, метафора-уособлення Романіст вирізняється радше лаконічним викладом думки, а саме завдяки введенню метафори потрібний настрій створюється способом вживання всього кількох влучних слів.

Науковий інтерес складає прагматична функція метафори, яка уособлює ставлення мовця до висловленого. Роман «Another Fine Myth» характеризується функціональною спрямованістю та орієнтацією на досягнення певної наперед поставленої мети, як i будь-який художній текст. Мета конкретного роману реалізується досить просто: розважальна функція за рахунок елементу комічного, оцінювальна функція за рахунок іронічної складової і висміювання тогочасних реалій, виражена за рахунок підтексту. Одначе, потрібно взяти до уваги той факт, що даний роман не ставить перед собою якихось глибинних цілей, він $є$ продуктом масс-маркету, який має досить широку аудиторію, і створений 3 комерційних поглядів.

Базовим прийомом дослідження прагматики метафори в романі «Ще один дивовижний міф» є висування (англ. foregrounding). Висування характеризується як засоби формальної організації тексту, які концентрують увагу читача на певних елементах повідомлення. Такі елементи викликають здивування своєю несподіваністю, непередбачуваністю з метою підкреслення, виділення певної думки. Основним видом висування, використаними щодо роману Р. Аспріна, є стилістична конвергенція.

Стилістична конвергенція - кількісний прояв висування, який характеризується накопиченням і сполученням стилістичних елементів у тексті. Використання цього методу є не досить доцільним в гумористичному фентезі, але за предмет аналізу були взяті ті сполучення, які містять в своїй основі метафору:

«The book snapped shut like the jaws of a hungry predator, trapping the missile within its haunting grasp»

Суттєву роль у стилістичних конвергенціях можуть відігравати алюзії. Власне кажучи, алюзія є сама по собі важливим типом висування. Аспрін доволі часто користується натяками на загальновідомі історичні чи побутові факти. Найповніше це виражено в епіграфах до розділів, кожен з яких представлено у вигляді несправжніх цитат відомих історичних постатей.

Висновки до даного дослідження. Ми визначили проблематику прагматичного дискурсу впродовж його розвитку та дослідили прагматичний ефект усіх функціональних стилів. Також було розглянуто вплив різних видів метафори на досягнення такого ефекту на основі виконуваних нею функцій. 
Також було досліджено види метафори, які були використані в романі, найбільшу частку яких складають метафори-уособлення та розкрита метафора. Було досліджено прагматичний ефект аналізованих метафор за допомогою базового прийому дослідження - висування, і його основного виду стилістичної конвергенції.

\section{Література:}

1. Бацевич Ф. С. Вступ до лінгвістичної прагматики. Підручник. К.: ВЦ «Академія», 2011. - $304 \mathrm{c.}$

2. Бацевич Ф.С. Розвиток ідей лінгвістичної прагматики в Україні [Електронний ресурс] / Флорій Бацевич // Розвиток ідей лінгвістичної прагматики в Україні. - 2015. - Режим доступу до ресурсу: http://prlingv. at.ua/publ/statti_2015/florij_bacevich_rozvitok_idej_lingvistichnoji pragmatiki_v_ukrajini/3-1-0-48.

3. Ємець О. В. Роль стилістичних засобів у творенні прагматичного ефекту художнього тексту [Електронний ресурс] / О. В. Смець // Науковий блог. Національний університет «Острозька академія». - 2013. - Режим доступу до ресурсу: https://naub.oa.edu.ua/2013/rolstylistychnyh-zasobiv-u-stvorenni-prahmatychnoho-efektu-hudozhnohotekstu/.

4. Bambini V. Metaphor and Experimental Pragmatics: When Theory Meets Empirical Investigation / V. Bambini, D. Resta. // Humana.Mente Journal of Philosophical Studies. - 2012. - P. 37-60.

\section{Бобер Анастасія}

(м. Житомир, Украӥна)

Житомирський державний університет імені I. Франка

\section{ВИКОРИСТАННЯ КОМУНІКАТИВНОГО ПІДХОДУ ДЛЯ ФОРМУВАННЯ ІНШОМОВНОЇ ПРОДУКТИВНОЇ КОМПЕТЕНТНОСТ}

У тезах розглядаються особливості використання комунікативного підходу для формування іншомовної продуктивної компетентності на старшому етапі вивченні іноземної мови.

Ключові слова: комунікативний підхід, іншомовна продуктивна компетентність.

В тезисах рассматриваются особености использования коммуникативного подхода $к$ формированию иноязычнои продуктивной компетентности на старшем этапе изучения иностранного языка

Ключевые слова: коммуникативный подход, иноязычная продуктивная компетентность.

The peculiarities of using communicative approach for the development of foreign-language productive competence at the senior stage of studying English are regarded in the work.

Key words: communicative approach, foreign language productive competence.

Мова $є$ найважливішим засобом людського спілкування, і без неї неможливий розвиток суспільства та його існування. Основним призначенням предмету іноземної мови $€$ формування умінь та навиків спілкування в усній та писемній формі, тому можемо стверджувати, що комунікативний підхід є невід'ємним елементом продуктивної складової. Сучасна система навчання іноземних мов дає можливість застосувати комунікативний підхід як важливий засіб полікультурного спілкування.

(C) Бобер Анастасія, 2018 
Комунікативний підхід при формуванні комунікативної компетентності на старшому етапі вивчення іноземної мови привертав увагу багатьох вітчизняних та закордонних науковців, таких як Б. В. Бєляєв, Л. В. Биркун, П. Б. Гурвіч, Г. О. Китайгородська, Ю. І. Пассов, В. Г. Редько, Т. Л. Сірик, Н. К. Скляренко, А. П. Старков та багато інших [1, с. 67]. Але матеріальна база використання комунікативного підходу при формуванні іншомовної продуктивної компетентності на старшому етапі вивчення іноземної мови є доволі малою і не окреслює коло переваг використання, тому ми можемо стверджувати про актуальність дослідження даної теми.

Одним із найголовніших принципів комунікативного підходу на старшому етапі вивчення іноземної мови є ситуативність, що передбачає організацію навчання у природних для спілкування умовах. Саме тому формування іншомовної продуктивної компетентності має відбуватись із використанням комунікативних ситуацій, зокрема проблемних. Застосування проблемних продуктивних ситуацій з метою моделювання реального та фахового спілкування [5, с. 45-51] є обов'язковою умовою реалізації принципу мовленнєво-розумової активності та самостійності учнів. Розглядаючи проблемні продуктивні ситуації, студенти не лише формують іншомовну продуктивну компетентність, а й підвищують свою мотивацію задля подальшого вивчення іноземної мови.

Комунікативний підхід під час формування продуктивної компетентності на старшому етапі вивчення іноземної мови припускає навчання граматики на функціональній та інтерактивній основі. Це означає, що засвоєння нових граматичних і лексичних одиниць відбувається у тісному зв'язку з їх функціями в мовленні не у вигляді «форм» та «структур», а як засіб відображення певних думок та комунікативних намірів [5, с. 77].

Комунікативний підхід для формування іншомовної продуктивної компетентності на старшому етапі обов'язково має дотримуватись принципу діалогу культур, що виглядає таким чином: 1) створення навчального комунікативного середовища, де відбувається ознайомлення, зустріч та здобуття умінь іноземної культури, мови, традицій; 2) використання такого змісту навчально-методичних матеріалів на старшому етапі, що моделює міжкультурну комунікацію; 3) організація міжкультурної комунікації з носіями іноземної мови та культури, стимулювання формуванню толерантності, спостережливості, спроможності змінити перспективу власної країни і подивитися на світ з іншої сторони [2, с. 6].

Отже, ефективність процесу формування іншомовної продуктивної компетентності визначає готовність студентів брати участь у міжкультурній комунікації мовою, яку вивчають. Комунікативний підхід є надзвичайно ефективним засобом, оскільки забезпечує зорієнтоване, дійове навчання іншомовного спілкування. Використання даного підходу сприятиме формуванню продуктивної компетентності, розвитку практичних умінь спілкування іноземною мовою.

\section{Література:}

1. Гальскова Н. Д. Межкультурное обучение: проблема целей и содержания обучения иностранным языкам // ИЯШ. - 2004. - № 1. C. 3-8.

2. Забродський М. М. Основи вікової психології. - Тернопіль: Навчальна книга, 2006. - 112 с.

3. Зубенко Т. В. Комунікативний підхід до навчання іноземної мови учнів початкової школи як стратегічна проблема у підготовці майбутнього вчителя Науковий вісник Миколаївського державного університету: Збірник наукових праць. - Випуск 20: Педагогічні науки. - Том 1 / За заг. ред. В. Д. Будака, О. М. Пєхоти. - Миколаїв: МДУ, 2008. - С. 206-211.

4. Колодько Т. М. Використання інтерактивних технологій у процесі професійної підготовки майбутнього вчителя / Тетяна Миколаївна Колодько // Система і структура східнослов'янських мов. - Київ: Знання України, 2008. - С. 275-282.

5. Пассов Е. И. Коммуникативный метод обучения иноязычному говорению / Е. И. Пассов. - Москва: Просвещение, 1991. - 223 с. 
УДК 81 '373.7

\section{Бобков Вадим}

(м. Острог, Украӥна)

Начіональний університет «Острозька академія»

\section{СТЕРЕОТИПНЕ СПРИЙНЯТТЯ МЕТРОЛОГІЧНОЇ ФРАЗЕОЛОГІЇ (анГЛ., нім., пол., укр. мови)}

Тези присвячено стереотипному сприйняттю метрологічної фразеології в англійській, німецькій, польській та укра їнській мовах. Використано метрологічні ФО з компонентомзагальною назвою міра, назву одиниці приблизного лінійного виміру лікоть, назву великої одиниці об' 'му сипких тіл мінок.

Ключові слова: фразеологія, стереотип, стереотипне сприйняття, метрологічні ФО, міра, лікоть, мішок.

Тезисы посвящены стереотипному восприятию метрологической фразеологии в английском, немеиком, польском и украинском языках. Использовано метрологические ФЕ $\mathrm{c}$ компонентом-обшим названием мера, названием единиць приблизительного линейного измерения локоть, названием большой единицы объема сыпучих тел мешок.

Ключевые слова: фразеология, стереотип, стереотипное восприятие, метрологические ФО, мера, локоть, мешок.

The research is dedicated to stereotypical perception of metrological phraseology in the English, German, Polish and Ukrainian languages. Metrological phrasal units with the following components have been used: the general name of measure, the unit of approximate linear measurement «elbow», the name of the big volume unit of granular materials «sack».

Key words: phraseology, stereotype, stereotypical perception, metrological idioms, measure, elbow, sack.

Метрологічна фразеологія англійської, німецької, польської та української мов складає значний за обсягом пласт мовних одиниць, які містять цікаву інформацію про склад мислення носіїв мови, їхнє світосприйняття та історію. Назви метрологічних понять лягли в основу метрологічних $Ф О$, що мають стереотипне сприйняття і яскраву національно-культурну семантику у чотирьох мовах. Це пояснюється тим, що у минулому на метрологічні поняття впливали економічні відношення між країнами, накладалися метрологічні системи сусідніх народів, що й позначилося на розвитку стереотипного сприйняття метрологічної фразеології.

Стереотипне у трьох описуваних мовах сприйняття значення «не рівняй усього до себе» реалізується у синонімічних ФО: нім. man kann nicht alle Schuhe über einen Arsch besetzen; nie należy mierzyć wszystkich swoją miarą/ miarką; укр. не можна всіх одною міркою міряти; не міряй своєю міркою.

Ці ФО походять 3 давніх часів, коли лінійні міри, міри об'єму та місткості сипких тіл та рідин були неточними і тому кожен купець намагався використовувати вигідну йому мірку (лікоть, мішок). При купівлі купці використовували більші міри (тобто свої), а при продажу менші міри. Тому у цих ФО зберігся стереотип вживання метроніма-реалії міра 3 виразно негативною конотацією «неточність, необ' єктивність». Дослідник слов'янської фразеології М. І. Тепляков зазначає, що ці метрологічні ФО мають переносний смисл і несуть інформацію про особисту користь, зацікавленість і суб'єктивність виконавця діі. Історична пам'ять багатьох поколінь мовців узагальнила найпростіші асоціативні характеристики компонентів ФО, створивши цим самим фрагмент мовної картини світу, що засвідчує інформацію про те, що в давні часи не існувало єдиної системи мір і тому впродовж тривалого часу метрологічні одиниці внормовувалися. У цих ФО відображена спроба встановити загальну, єдину для всіх, уніфіковану систему мір вимірювання, одну мірку.

У чотирьох мовах використовувалась аналогічна міра довжини - англ. yard-stick/ yard, нім. Elle, пол. lokieć, укр. лікоть, тому існували умови для виникнення стереотипного образу у цілому ряді ФО: англ. to measure others/ other people by one's own yard-stick; to measure smb by your own yard, to measure others by one's own yard-stick; нім. alle Leute mit der gleichen Elle messen (wollen); пол. mierzyć innych swoim tokciem; англ. 
to measure another's corn by one's own bushel; пол. mierzyć innych wlasnym lokciem; укр. міряти/ зміряти своїм/ іншим ліктем «оцінювати інших людей за своїми власними стандартами; суб'єктивно».

Цей варіантно-синонімічний ряд представляє яскраві національно-культурні особливості у чотирьох мовах. Їхня внутрішня форма, характер їхньої семантики і функціонування є стереотипними у чотирьох мовах. У сучасних носіїв чотирьох досліджуваних мов слово лікоть асоціюється з стереотипним поняттям приблизного лінійного виміру.

У наведених ФО відбулися стереотипні метафоричні переосмислення, що виникли на основі емоційного і експресивного висловлювання, яке позначає додаткові асоціативні ознаки і оцінні характеристики. Власне накладання прямого і переносного значень у цих метафоричних ФО становить основу їхньої стереотипної образності, незважаючи на те, що кожна 3 чотирьох мов зберегла у складі цих ФО свої національні одиниці вимірювання як на позначення лінійних мір, так і на позначення мір об'єму та місткості сипких тіл та рідин: англійці bushel, yard-stick, yard; німці Elle; поляки lokieć; українці лікоть, аршин.

Негативна семантика цих ФО сформувалася шляхом стереотипного сприйняття компонентів: англ. one's own; пол. swój, inny; укр. свій, інший «вигідний лише собі самому; не відповідає стандартам», які вносять негативні смислові відтінки у семантику ФО - «застосовувати однакову або неоднакову оцінку; оцінювати когось суб' єктивно». ФО передають недовірливе стереотипне ставлення мовців до неточних мір, які в минулому застосовували купці, щоб отримати більше грошей.

Джерелом виникнення і утвердження двох антонімічних ФО нім. man kann nicht alles mit der Elle messen; укр. не можна все виміряти ліктем також $є$ стереотипне недовірливе ставлення німців і українців до неточної одиниці виміру (нім. Elle, укр. лікоть), яку використовували до прийняття міжнародної системи мір і ваги.

Існують ФО з метронімом пол. łokieć; укр. лікоть, які мають професійно-торговельне походження: пол. lokciem i miarką; tylko lokciem i miarką; укр. ліктем і міркою. Вони набули метафоричного значення «жити за розрахунком; бути скупим», мають стереотипну негативну конотацію і дають експресивно-оцінну характеристику професійної риси купців. Найближчий контекст цих ФО характеризується вживанням дієслів mierzyс́, міряти; żyć, жити. Наприклад ФО: пол. lokciem i miarką mierzyć/ żyć tylko lokciem i miarką; укр. міряти/ жити ліктем і міркою, які образно передають основний вид діяльності купців - міряти і важити. Ще одне стереотипне значення ФО пол. lokciem i miarką mierzyć/ żyć tylko łokciem i miarką; укр. міряти/ жити ліктем і міркою - «торгівля, заняття купця; перевагу фінансових інтересів над іншими інтересами людини».

Метронім англ. Sack/ bag, нім. Sack, пол. worek, укр. мішок, що є назвою великої одиниці об'єму і місткості сипких тіл, який має давнє походження, також $є$ компонентом стереотипних ФО у чотирьох мовах. Вони мають багату культурну, духовну та історичну інтерпретацію, це ФО: англ. a beggar's purse is bottomless/ the beggar's wallet has no bottom; нім. ein leerer Sack steht nicht aufrecht; пол. dziurawy worek; укр. дірявого мішка не насиплеш; дірявий мішок «надзвичайно марнотратна людина, яка витрачає гроші для заспокоєння своїх забаганок». Ці метрологічні ФО вживається на позначення негативної характеристики людини.

Спільна індоєвропейська спадщина позначилась на виникненні метрологічних $Ф О$, в яких особливості форми мішка лягли в основу їхнього стереотипного осмислення. У трьох мовах існують ФО, які дають стереотипну негативну оцінку широкого одягу, що вільно звисає й не пасує людині: нім. an j-m wie ein Sack hängen; пол. coś wisi na kimś jak worek/ jak na kołku/ jak na kiju/ jak na wieszaku; укр. щось висить/ сидить на комусь як мішок/ як торба. В основі образності цих $є$ назва одиниці приблизного великого виміру Sack (мішок) своїм корінням сягає XVIII ст., коли слово sack позначало вільну жіночу сукню.

Коли носії чотирьох мов говорять про якусь таємницю, про те, що якась інформація довгий час не розголошувалась, але стала явною вони вживають стереотипні ФО: англ. the cat is out of 
the bag; нім. die Ahle im Sack verrät sich durch ihre Spitze; die Sonne bringt alles an den Tag / Es ist nichts so fein gesponnen, es kommt doch endlich an die Sonne; Es kommt alles an den Tag, was unterm Schnee verborgen lag; пол. wyszło szydło z worka; wylazło coś jak szydło z worka; укр. шила в мішку не сховасш; не втаїш ти шила в мішку, бо все одно вилізе; вийшло/ вилізло шило з мішка/ торби. Ці ФО мають різну формально-граматичну будову і дещо відмінне компонентне наповнення.

Стереотипний підхід до комунікативної ситуації спостерігаємо також у ФО: англ. the cat is out of the bag; нім. Wahrheit lässt sich nicht verbergen; пол. шуszło szydło z worka; wylazło coś jak szydło z worka; укр. правди, як шила в мішку, не сховаєш.

Для метрологічних ФО нім. das Danaidenfaß; ins (durchlöcherte) Faß der Danaiden; пол. beczka Danaid; укр. бочка Данаїд мають значення «праця, яка не закінчується і не приносить користі» характеризує роботу, яка забирає багато зусиль, грошей, але не приносить результату.

Синонімічне значення мають ФО: англ. a barrel without a bottom; нім. ein Faß ohne Boden; ein leerer Sack steht nicht aufrecht (італ. Sacco vuoto non sta ritto). Ці ФО відтворюють стереотипність образного сприйняття семантики «надзвичайно марнотратна людина, яка витрачає гроші для заспокоєння своїх забаганок». 3 синонімічною семантикою вживаються пол. worek / beczka / studnia bez dna та укр. бочка без дна «хтось або щось, в що вкладається багато праці/ роботи, грошей без видимого ефекту; про надмірну, надзвичайно велику кількість чогось».

Отже, узагальнюючи вище викладений матеріал, можемо ствердити, що метрологічна фразеологія англійської, німецької, польської та української мов є широковживаною і демонструє стереотипне сприйняття. Їхня семантика відображає узагальнене асоціативне ставлення мовців до вживаних у минулому назв метрологічних одиниць.

\section{Література:}

1. Культура і побут Англії [Електронний ресурс] - режим доступу:
2. Українська минувшина: Ілюстративний етнографічний довідник/ А. П. Пономарьов, Л. Ф. Артюк, Т. В. Косміна та ін. - Київ: Либідь, 1993. - 256 с.

3. Кудіна О., Пророченко О. Перлини народної мудрості. Німецькі прислів'я та приказки. - Вінниця: Нова книга, - 2005. - 319 с.

4. Agnieszka Jawór. Антропометричні назви мір у польській мові// Etnolingwistyka. Problemy jezyka i kultury. - Lublin: UMCS. - № 21. 2010. - 289 s.

5. Słownik frazeologiczny współczesnej polszczyzny. S. Bąba, J. Liberek. - Warszawa: Wydawnictwo Naukowe PWN, 2001. - 1096 s. http://www.litopys.org.ua 
УДК 811(100)(091)

\section{Божченко Владислав}

(м. Острог, Україна)

Національний університет «Острозька академія»

\section{ПОРІВНЯЛЬНО-ІСТОРИЧНИЙ МЕТОД КЛАСИФІКАЦІЇ МОВ СВІТУ}

У тезах проаналізовано походження порівняльно-історичного методу класифікації мов, його сучасний стан. Також названо основоположників порівняльно-історичного мовознавства та описано їх діяльність в иілому.

Ключові слова: класифікація, дослідження, спорідненість, метод, санскрит, граматика.

В тезисах проанализировано происхождение сравнительно-исторического метода классификачии языков, его современное состояние. Также названы основоположники сравнительно-исторического языкознания и описана их деятельность в иелом.

Ключевые слова: классификация, исследования, родство, метод, санскрит, грамматика.

The research analyzes the origin of comparative historical method of language classification, as well as its current state. Also, the founders of comparative historical linguistics are listed and a general description of their work is provided.

Key words: classification, research, affinity, method, Sanskrit, grammar.

Тема класифікації мов актуальна тим, що саме знання спорідненості і походження, а також групування у сім'ї деяких мов дозволяє філологам утворювати та використовувати набагато більшу кількість синонімів, омонімів, паронімів і т.п., «відкривати» нові мови, вирізняючи їх 3 поміж діалектів та говірок, а також збагатити свій словник запозиченими словами та виразами.

(C) Божченко Владислав, 2018
Порівняльно-історичний метод - це певна сукупність прийомів та засобів історико-генетичного дослідження мовних сімей і груп, а також деяких відмінних мов для встановлення закономірностей їх розвитку. Цей метод базується на реконструкції не зазначених писемністю наявних у минулому мовних фактів планомірним порівнянням пізніших фактів кількох конкретних мов, які були зазначені в писемних пам'ятках або які були уживані у мовленні [1].

Порівняльно-історичний метод - перший справді науковий метод вивчення мови. Його відкриття на початку XIX ст. стало можливим завдяки розширенню емпіричної бази мовознавства: появі описів безлічі нових мов, а в зв'язку з цим - ідеї порівняння та ідеї спорідненості мов; появі перших класифікацій мов. А також завдяки відкриттю санскриту та його дослідженню, адже це була одна з найдавніших письмових індоєвропейських мов, яка була дуже добре описана, зокрема, у відомій граматиці Паніні (IV-III ст. до н. е.). Відкривши граматику Паніні, європейські вчені отримали надійний матеріал для зіставлень 3 грецькою і латинською і змогли виявити спорідненість санскриту з європейськими мовами. В результаті майже одночасно у цілого ряду вчених, які отримали в розпорядження ці дані, виникла думка про спорідненість грецької, латинської та ін. Свропейських мов 3 санскритом і про те, що всі ці мови походять від однієї мови-предка - прамови, яка на жаль не збереглася. 3 кінця XVIII ст. до мовознавства починає активно проникати ідея історизму.

Багато в чому цьому сприяло зародження романтизму в європейській літературі. Романтики вельми активно цікавилися старожитностями: древніми мовами і літературою, національною історією і міфологією, національнім фольклором, шукали історичні корені своїх народів і мов. Якщо в епоху класицизму панували філософія раціоналізму і розуміння того, що всі мови побудовані на вічних і незмінних засадах - на законах логіки, людського мислення; то 3 романтизмом приходить розуміння того, що немає нічого постійного. 3 розвитком людини змінюється і людське мислення, і закони. Всі гуманітарні науки поступово осмислюються як науки історичні, вчених все більше починають 
цікавити проблеми генезису (походження) суспільних явищ і закономірності їх історичного розвитку.

Відкриттю порівняльно-історичного методу сприяла низка подій. Зокрема:

- 1789 - Петро Семенович Паллас і керована ним група академіків створюють «Порівняльний словник усіх мов і діалектів». Словник містив 285 словникових статей з матеріалами 3164 азіатських, 55 європейських, 33 африканських і 23 американських (індіанських) мов.

• 1808 - німецький філолог Фрідріх Шлегель в книзі «Про мову і мудрість індійців» також висловив думку про спорідненість індоєвропейських мов, але прамовою Шлегель вважав санскрит. Він вводить термін «індогерманські мови». Заслуга Шлегеля полягала в тому, що він показав спорідненість не тільки лексики, а й граматичного ладу індогерманських мов.

• 1811 - в Санкт-Петербурзі виходить анонімний трактат «Про подібність санскритської мови з російською», де наводиться 178 відповідностей санскриту зі слов'янською, грецькою, латинською і германськими мовами; крім того, був проведений порівняльний аналіз відмінювання дієслова «бути» в слов’янському (єсмь) і санскриті (asmu).

• 1812 - проф. Харківського ун-ту Б. О. Рейт видає книгу «Дух і літературна культура Сходу і Заходу», в якій основну увагу приділяє «Авесті» («Зендвесте»), давньо-персидському твору, проводить порівняння авестійських числівників з російськими.

Основоположниками методу вважаються чотири вчені: Расмус Раск (Данія), Франц Бопп, Якоб Грімм (Німеччина) і Олександр Христофорович Востоков (Росія), які прийшли до відкриття останнього майже одночасно на початку XIX ст.

А. О Білецький у статті «Сучасне порівняльно-історичне мовознавство (Проблеми та аксіоми)» зазначає, що сучасний порівняльно-історичний метод деякі вважають забутим та «пройденим етапом» у розвитку сучасного теоретичного мовознавства [2]. Ця думка існує лиш тому, що значних досягнень в сучасному порівняльно-історичному методі набагато менше, ніж їх було в XIX ст. Значними досягненнями в галузі порівняльно-історичного мовознавства, зокрема в галузі дослідження окремих груп індоєвропейських мов, а також тюркських, фіно-угорських, монгольських, тунгусо-маньчжурських та інших мов, характеризуються особливо радянське мовознавство, хоч розвиток компаративістики в нашій країні був певною мірою загальмований у зв'язку 3 великим поширенням т. зв. яфетичної теорії і нового вчення про мову М. Я. Марра.

Не зважаючи на нові теорії та зміни, порівняльно-історична програма, яка була створена ще в минулому сторіччі, базуючись на вивченні індо-європейських мов, і в наш час не втратила своїх позицій. Навіть більше, колишні теореми компаративістики зараз $\epsilon$ аксіомами для подальших досліджень, зокрема це стосується індоєвропейських мов.

Як висновок, порівняльно-історичне вивчення мов має не тільки науково-пізнавальне значення, а й велику науково-методичну цінність. Воно дає можливість розкрити таємниці давно зниклих цивілізацій, допомагає розшифрувати те, що не піддається розшифруванню протягом тисячоліть, загадки стародавніх написів на скелях та папірусах, дізнатися історію і «долю» окремих слів, діалектів і цілих маленьких і великих сімей.

\section{Література:}

1. Niki Foster What is the Comparative Method in Linguistics? [Електронний ресурс] / Sara Z. Potter Режим доступу: http://www.wisegeek. com/what-is-the-comparative-method-in-linguistics.htm

2. Білецький А. О. Сучасне порівняльно-історичне мовознавство (проблеми та аксіоми) / А. Білецький // Studia linguistica. - 2012. Вип. 6 (1). - С. 5-16. Режим доступу: http://www.library.univ.kiev.ua/ $\mathrm{ukr} / \mathrm{host} / \mathrm{viking} / \mathrm{db} / \mathrm{ftp} / \mathrm{univ} / \mathrm{sl} / \mathrm{sl}$ _2012_06_01.pdf 
УДК 81'367:070.1

Брожник Ольга

(м. Острог, Україна)

Начіональний університет «Острозька академія»

\section{СИНТАКСИЧНІ ЗАСОБИ ЕКСПРЕСИВНОСТІ}

\section{В АМЕРИКАНСЬКІЙ ОНЛАЙН-ГАЗЕТІ «ТНЕ ТIMЕS»}

У тезах проводиться аналіз англійських засобів експресивності на синтаксичному рівні на матеріалі американської онлайн-газети The Times.

Ключові слова: засоби експресивності, експресивний синтаксис, комунікативний потенціал, повтор, париелячія, паралелізм.

В тезисах проводится анализ английских средств экспрессивности на синтаксическом уровне на материале американской онлайн-газеты The Times.

Ключевые слова: средства экспрессивности, экспрессивный синтаксис, коммуникативный потенцииал, повтор, паричеллячия, параллелизм.

The research analyzes the English means of expressiveness at the syntactic level on the material of American on-line newspaper The Times.

Key words: means of expressiveness, expressive syntax, communicative potential, repetition, parceling, and parallelism.

Новизна статті полягає в тому, що в ній здійснюється комплексний аналіз синтаксичних засобів експресивності як один із методів увиразнення тексту та впливу на потенційного читача. Мета статті - простежити та дослідити вживання експресивних засобів в статтях онлайн-газети The Times шляхом аналізу їх синтаксичного рівня.

Об'єктом дослідження $є$ сучасні газетні онлайн-статті. Предметом дослідження обрано синтаксичні засоби експресивності, використані в статтях онлайн-газети The Times.

\footnotetext{
(с) Брожик Ольга, 2018
}

Теоретична значущість роботи полягає у визначенні поняття експресивного синтаксису, а також в аналізі особливостей засобів експресивності на синтаксичному рівні онлайн-статей газети The Times.

Синтаксис публіцистичного стилю мови теж має свої особливості, пов'язані з активним вживанням емоційно і експресивно забарвлених конструкцій. Так, визначаючи поняття експресивного синтаксису, можна звернутись до такого позначення: сукупність продуктивних і часто вживаних експресивно та емоційно насичених синтаксичних побудов, які забезпечують особливу виразність тексту та виконують певні стилістичні функції у сприйманні та розумінні репортажу: вставні конструкції, повтори, окличні речення, парцельовані конструкції [1, с. 2-7].

Серед синтаксичних засобів найпопулярнішими у американській публіцистиці є повтор, паралелізм, парцеляція, еліпсис, чергування довжини висловлювань і характерних граматичних конструкцій. Метою таких засобів є спроба автора звернутись та апелювати до думки читача, викликати його до діалогу. Наприклад, вживання еліпсису в статті онлайн-журналу The Times закликає читачів до дій: «Quite good for you - very bad for the planet. How far out is too far out for New York's fading club scene?» [2, с. 26-31].

Варто подати конкретні приклади вживання засобів експресивності на синтаксичному рівні, почерпнуті зі статей онлайн-газети The Times:

a) вживання окличних речень різного значення Claws out! Why pop culture clings to the crazy cat lady;

б) питальних речень How do you picture her? Unkempt hair, dressing gown and slippers, living alone, rarely leaving the house?

в) речень зі звертаннями When you're younger, you assume life will turn out a particular way because you haven't lived it yet.

г) риторичних питань When public money brings windfalls to a few, why should the state not take a share?

д) повторів The orator said, "Good morning to the old, good morning to the young, good morning to each and every one present.» 
Крім того, прагнення до експресії обумовлює використання конструкцій $з$ розмовним забарвленням: речень 3 частками, вигуками, речень фразеологічного характеру, інверсій, безсполучникових речень тощо. У сучасних статтях для більшої правдоподібності того, про що мовиться у тексті, вживаються вставні одиниці, які виражають ставлення мовця до способу оформлення висловлень, вказують на характер висловлення. Найчастіше вживаються вставні конструкції to be honest, to tell the truth, indeed, genuinely, frankly speaking etc. До прикладу:

They clapped, they beamed, they leapt to their feet to welcome a speech that, truth to tell, was more a statement of intent than a program for government;

There are moments when the character's post-marriage angst is genuinely heartbreaking;

That statement was, indeed, a tribute to the actress, who stole the hearts of Tamil cinema-viewers.

Отже, засоби експресивності синтаксичного рівня в тексті американських статей мають потужний комунікативний потенціал. Вставні слова, словосполучення, речення, за допомогою яких здійснюється модальне та емочійно-експресивне очінювання повідомлення, виступають для уточнення, роз'яснення, доповнення змісту основного речення, вказують на певні деталі чи нові факти, щчо не були передбачені в момент формування думки $[3$, c. 11$]$.

\section{Література:}

1. Бикова О. М. Способи досягнення емотивно-експресивного ефекту текстів польського тексту / О. М. Бикова. - 2013. - №2. C. $2-7$.

2. Громова Н. Лінгво-стилістичні особливості газетних текстів англомовної преси як засоби впливу на читацьку аудиторію / Надія Громова. // Вісник Львівського університету. Серія іноземні мови. 2016. - № 23. - С. 26-31.

3. Кожина М. Н. Про мовну та мовленнєву експресії і їхні екстралінгвістичні обгрунтування / М. Н. Кожина. - Ростов: Ростовський університет, 1987. - С. 8-17.

\section{Войщіховський Ілля}

(м. Острог, Украӥна)

Начіональний університет «Острозька академія»

\section{НАЦІОНАЛЬНО-КУЛЬТУРНІ ОСОБЛИВОСТІ АНГЛОМОВНОЇ ЕЛЕКТРОННОЇ КОМУНІКАЦІї}

Розглянуто сучасне середовище електронної комунікації та виявлено національно-культурні особливості англомовної електронної комунікації. Проаналізовано взаємовплив мовних і соиіокультурних механізмів в просторі Інтернет-спілкування. Описано лінгвостилістичні особливості Інтернет-мови та наведено їх приклади.

Ключові слова: Інтернет, електронна комунікація, соцмережа, Інтернет-спілкування.

Рассмотрено современную среду электронной англоязычной коммуникации и обнаружень национально-культурные особенности электронной коммуникации в английском языке. Проанализировано взаимовлияние языковых и сочиокультурных механизмов в пространстве Интернет-общения. Описаны лингвостилистические особенности Интернет-языка и приведены их примеры.

Ключевые слова: Интернет, электронная коммуникация, соисеть, Интернет-общение.

The modern environment of electronic communication is considered and the national cultural features of electronic communication in English are revealed. The mutual influence of linguistic and socio-cultural mechanisms in the space of Internet communication is analyzed. Linguisticistic features of Internet languages are described and their examples are presented.

Key words: Internet, electronic communication, social network, Internet communication.

Інтернет трактують як поєднання інформаційних технологій i технічних засобів, як психосоціальний феномен, як мережеве (C) Войціхховський Ілля, 2018 
співтовариство, як універсальну базу даних. До вищесказаного варто додати лінгвістичну сторону вивчення Інтернету, тому що iї вплив на рівень розвитку мови, яка обслуговує віртуальну реальність, має все більше значення [1, с. 3].

Інтернет як нова платформа для спілкування швидко розвивається, а тому з'являється потреба вивчати та аналізувати явища та процеси його роботи та функцій. У зв'язку з цим, останнім часом збільшується кількість лінгвістичних праць, що описують віртуальний дискурс. Вивчається специфіка комунікативної прагматичності і функціональності інтернет-середовища (О. Галичкина, Л. Щипіцина, S. Herring, R. Holt, A. Iskold та ін.), вплив сучасних електронних технологій на мову (М. Бергельсон, Л. Іванов, N. Baron, D. Crystal, C. Thurlow та ін.), взаємозв'язок усного й письмового спілкування в інтернет-мережі (М. Бергельсон, А. Войскунский, Л. Іванов та ін.).

Метою дослідження $є$ виділення національно-специфічних особливостей електронної комунікації в англійській мові, аналіз взаємовпливу мовних і соціокультурних механізмів в просторі Інтернет-спілкування.

Об'єктом дослідження є електронне спілкування, під яким розуміється вербальний взаємозв'язок в глобальній комп'ютерній мережі Інтернет. Предметом дослідження є національно-культурні особливості електронної комунікації в англомовному комунікативному середовищі.

Основу сучасної електронної комунікації (ЕК) становлять персональні комп'ютери, телекомунікаційні системи, бази даних та Інтернет, умовою функціонування яких є цифрові технології перетворення інформації. Через інноваційні інформаційні технології, обмін інформацією тепер дешевший та швидший, став глобальним процесом, вийшов за межі локацій свого генерування.

ЕК - це наслідок розвитку інформаційних технологій і насамперед автоматизованих технологій генерування, обробки, збереження, передачі та поширення документалізованої інформації.

Технічні аспекти сучасної комунікації, розширення сфери ЕК не змінюють її сутності, оскільки це є проявом системних меха- нізмів розвитку сучасного суспільства та основою становлення системи соціальних комунікацій.

В англійських лексикографічних джерелах для трактування інтернет-мови вживають такі визначення: e-language, netlingo, e-talk, netspeak, weblish, а комунікативне середовище іiі використання називається комп'ютерно-опосередкована комунікація (Computer Mediated Communication).

Означений вид комунікації має багато відмінностей від традиційної, виокремлюється розвитком інформаційних технологій і описується складними жанровими комбінаціями, що складаються з гіпержанрів (сайт, блог, соціальна мережа) і жанрів (електронний лист, форум, чат, пост, коментар) [2, с. 4].

Американський лінгвіст Д. Кристал (D. Crystal), коли описував мову Інтернет-спілкування, запропонував наступну формулу: «усна форма мови + письмова форма мови + ознаки, опосередковані комп'ютером» [4, с. 33].

Мовна поведінка користувачів інтернет-комунікації визначається спеціальними правилами мережевого етикету (netiquette), в якому використовується жаргонна лексика, велика кількість абревіатур та скорочень, терпимість до помилок, використання «смайлів» (від англ. smiley - піктограма, яка показує емоції), які впливають на уточнення сенсу повідомлень, дають їм емоційноекспресивного забарвлення.

В англомовних текстах мережі Інтернет варто виділити такі групи жаргонної лексики: комп'ютерний інтернет-жаргон (userpic - фото учасника, flamer - флеймер, користувач, який відправляє повідомлення з ціллю образити адресата, aka - also known as також відомий як) та молодіжний Інтернет-жаргон (for sho - for sure -без сумніву, rents - parents - батьки, beast - класний).

Інтернет-жаргон показує приналежність Інтернет-користувачів до окремих субкультур, закритих для інших, які проявляють певні лінгвокреативні вміння у його створенні. Варто зазначити, що активні словотворчі процеси притаманні лексичному рівневі інтернет-текстів в загальному.

3-поміж лінгвостилістичних особливостей текстів постів можна виокремити такі: вживання великої кількості новостворених 
слів (applet, weblog, webcast); наказових та односкладних речень (Make sure your feet rest firmly on the floor); специфічних інтернеттермінів (gadget, cluster, hypertext links); особових займенників першої і другої особи, що дає відчуття приналежності користувачів до окремої субкультури, єдиного цілого, а також використання різних художніх засобів, таких як метонімія, метафора, евфемізм (The new killer apps are interactive, transaction intensive and let us do business in more meaningful ways).

Вираження принципу комунікативної ввічливості в електронному спілкуванні здійснюється в існуванні певних правил підтримки електронного мовного етикету в соцмережах, що називаються «нетикет» (netiquette = net+ etiquette). Наприклад, такі, що обмежують електронне повідомлення однією темою й виділяють іiі особливим рядком.

Прикладом скорочень можуть слугувати «неткроніми» (netcronyms) - репліки, що використовують для підтримки спілкування, для прикладу назвемо такі: F2f - face-to-face, AFAIK - as far as I know, BTW - by the way.

Комунікативний принцип заощадження часу та старань виявляється не тільки у використанні абревіатур, а й у такому спеціальному спрощенні фраз у сфері лексики, як акронімія.

Так, у електронній комунікації можливе поєднання складних слів, наприклад, символ «е» від слова electronic у скороченні перетворюємо в префікс: e-text, e-management. Також можна зустріти скорочення символу «v» від virtual: v-chat, v-party.

Цікавим є також поєднання символу@з зншими словами для подальшого переосмислення складних слів, наприклад: atcommand,@-party,@-address,@ café. Символ \% може замінити подвоєння букви «оо»: $\mathrm{c} \% 1=\mathrm{cool}$.

Учасники електронної комунікації часто використовують маленькі букви замість великих, щоб не витрачати зусилля на натискання на клавішу верхнього регістру: Webmaster, telnet = WebMaster, TelNet. У мережі існує тенденція до використання тільки рядкових букв: john are you going to london next week? замість John, are you going to London next week? Варто відмітити, що протилежне явище буде прийнято як вираження сильної емо- ційності відправника повідомлення й належить уже до реалізації принципу виразності.

Принцип економії й зручності також проявляється, якщо не натискають клавішу пропуску або дефіса, що призводить до суцільного написання складних слів: startup, homepage, замість start up, home page; weyware (brain), webhaed (webaddict).

Прикладом безпосереднього виразу емоцій і настроїв можуть служити також графічні заходи. До них відносять:

- множинне повторне написання букв: yeeessss, oooops.

- перебільшена кількість написання знаків пунктуації: whole????. hey!!!

- використання всіх заголовних літер замість рядкових для виразу емфатичного наголосу: I SAID NO.

• позначення логічного наголосу за допомогою клавіші «зірочка»: The *real* answer.

Крім цього, для вираження своїх почуттів, емоцій та психічного стану, візуалізації тексту, використовуються смайлики, математичні символи, пунктуаційні малюнки. Це все пояснюється тим, що головною функцією спілкування є донесення своєї думки, передання емоцій.

За історію свого розвитку Twitter розвинув свою власну унікальну мову - twitspeak, що існує за власними законами, та етикет - twittiquette, у якого є своя унікальна структура [5, с. 285].

Говорячи про особливість спілкування в соціальній мережі Twitter, слід відмітити, що нещодавно у повідомленні можна було використовувати не більше, ніж 140 символів. I тому під час спілкування часто використовували прості речення. Це робить спілкування динамічним, що посилює відчуття реальної розмови. Обмеження кількості символів робить виклад своїх думок лаконічним, що позитивно впливає на інформативність стрічки новин. В серпні 2015 року Twitter зняв обмеження кількості символів на особисті повідомленуz, що сприяло виникненню довших речень, які роблять мову складнішою для розуміння.

У спілкуванні в соцмережах проявляється декілька видів комунікації: міжособистісна, міжгрупова, міжсоціумна, комуніка- 
ція між собою і групою, між групою та суспільством, між особою та суспільством [6, с. 285].

До основної характеристики інтернет-мови належить збільшення аграматизму - відхилення від синтаксичних і пунктуаційних норм літературної мови з боку продуцента тексту. Аграматизм часто проявляється в неправильному або неповному використанні розділових знаків і інколи - в неузгодженості, порушенні формальності та синтаксичності між викладом думок (анаколуф), порушенні порядку слів у реченні, відсутності інверciï в питаннях: ifine = Iamfine, meis 31, youfeelingbetternow? [3]; і різних обривах (апосіопеза і прозіопеза), таких як: takeyoshoeso ffwhenyuwalkinthehouse..!; denydenydeny !! [3]; пропущення слів, допоміжних слів, порушення узгодження між членами речення; невірне вживання прописних букв (капіталізація і декапіталізація): idon'tknow, howyadoin, igotenuf, thN = then, $n E d=$ need [3].

Використання графічних та лексичних скорочень, а також написання букв цифрами теж характерне для спілкування в соцмережах. В Інтернеті незручно використовувати довгі слова, тому що важливою $є$ швидкість написання повідомлення. Тому багато користувачів починають використовувати скорочення, які зберігають сенс:

- Path acquired by makers of a messaging app, will focus on Southeast Asia.

- 2 day I'm going 2 visit my bestie, HB2Umy dear!!

- Again, they aren't migrants - they are refugees fleeing from their homes in $N$ Africa \& Middle East as a result of Obama leading from behind [3].

Глобальна мережа Інтернет нині є тією сферою, у якій створюється характерне новоутворення сучасного суспільства, так звана письмова розмовна мова електронної комунікації, яка заснована на літературній письмовій мові і характеризується активним використанням елементів неформального розмовного мовлення та графічних символів. Характерними рисами інтернет-дискурсу як функціонального різновиду діалогів і монологів у мовленні $є$ нелінійність і відкритість, відсутність обмежень у часі і просторі, існування у складній жанровій системі, специфічна лексика.
У електронній сфері склалися свої особливі принципи спілкування, які мають відмінності з традиційним листуванням або розмовою у реальному житті. Часто використовується принцип заощадження часу та старань написанням абревіатур або комбінації букв, цифр, які в англійській мові існують як окремий склад, граматична конвенсія, принцип виразності через використання смайлів та графічних заходів тощо.

Соціальні мережі, де часто здійснюється спілкування через написання текстів, створюють такий спосіб комунікації, який за своїм виглядом нагадує усний розмовний стиль. Застосування знаків та символів, які не властиві традиційній письмовій мові, створення ефекту звуковимови, користування певними словесними формулами тощо зближують письмовий вид комунікації з його усним варіантом.

\section{Література:}

1. Warschauer M. Online communication [Електронний pecypc] / M. Warschauer // The Cambridge guide to teaching English to speakers of other languages. - Cambridge : Cambridge University Press, 2001. P. 207-212. - Режим доступу : http://gse.uci.edu/person/warschauer_m/ oc.html.

2. Hollenbaugh E. E. The Effects of Anonymity on Self-Disclosure in Blogs: An Application of the Online Disinhibition Effect Communication / E. E. Hollenbaugh, M. K. Everett // Journal of Computer-Mediated Communication. - 2013. - Vol. 18 (3). - P. 283-302.

3. Тулупов В. Вызов современной журналистике / В. Тулупов. - Режим доступа: http://www.re1ga.ru/Environ/WebObjects/tgu- www.woa/ wa/Main?textid $=3584 \& 1$ eve $11=$ main $\& 1$ eve12=articles.

4. Crystal D. Language and the Internet / D. Crystal. - 2-d edition. Cambridge: Cambridge University Press, 2006. - 318 p.

5. Горошко О. І. Гендер у мережі: становлення теоретичної парадигми // Вісн. МСУ: Соціол. науки. - 2006. - Т. IX, № 2. - С. 3-9.

6. Землякова О. О. Лінгвостилістичні характеристики жанру англомовного корпоративного блогу : автореф. дис. ... канд. філол. наук : спец. 10.02.04 / О. О. Землякова. - Харків, 2010. - 20 с. 
УДК 81 '373:070.41

\section{Воробей Вімалій}

(м. Острог, Украӥна)

Начіональний університет «Острозька академія»

\section{ЛЕКСИЧНІ І СТИЛІСТИЧНІ ОСОБЛИВОСТІ ПУБЛІЦИСТИЧнОГО СТИЛЮ}

Тези присвячено дослідженню основних ознак публіцистичного стилю; мовну і прагматичну варіативність, а також експресивну, образну функиію неологізмів та фразеологізмів у сучасному газетно-публіцистичному дискурсі.

Ключові слова: публічистичний стиль; газетно-інформаиійний стиль;неологізми, фразеологія.

Тезисы посвящена исследованию основных признаков публичистического стиля; языковую и прагматическую вариативность, а также экспрессивную, образную функциюю неологизмов и фразеологизмов в современном газетно-публииистическом дискурсе.

Ключевые слова: публицистический стиль; газетно-информационный стиль; неологизмы, фразеология.

The research is devoted to the study of the main features of the journalistic style; linguistic and pragmatic variability, as well as expressive, figurative function of neologisms and phraseological units in contemporary newspaper-journalistic discourse.

Key words: journalistic style; newspaper informational style; neologisms, phraseology.

Публіцистичний стиль є прямим нащадком давньої риторики. Хоча саме поняття публіцистичного стилю трактується в різних авторів неоднаково. Так, І. Арнольд ототожнює його з газетним стилем $[1$, с. 90$]$, Ю. Скребнев розглядає його як одну з різновидів газетного стилю, І. Гальперин поєднує в це поняття стиль газетних статей, стиль ораторський і стиль есе.

(C) Воробей Віталій, 2018
Призначення публіцистичного стилю - повідомляючи, переконувати, впливати на маси, формувати в людей певне відношення до різноманітних проблем, повідомляти інформацію, що має суспільне значення. Публіцистичний стиль використовується в газетах, журнальних статтях, у передачах на радіо і телебаченні, у виступах на зборах, нарадах і мітингах.

Публіцистичний стиль знаходить застосування в суспільнополітичній літературі, періодичній пресі (газетах, журналах) та в різноманітних виступах і промовах. У межах публіцистичного стилю широке поширення одержав його газетно-журнальний різновид. До основних рис якого відносяться: економія мовних засобів, лаконічність викладу при інформативній насиченості; наявність суспільно-політичної лексики і фразеології, переосмислення лексики інших стилів (зокрема, термінологічної) для цілей публіцистики; використання характерних для даного стилю мовних стереотипів, кліше; жанрова розмаїтість і зв'язана $з$ цим розмаїтість стилістичного використання мовних багатозначності слова, ресурсів словотвору (авторські неологізми), емоційно-експресивної лексики; використання зображувально-виразних засобів мови, зокрема засобів стилістичного синтаксису (риторичні питання і вигуки, паралелізм побудови, повтори, інверсія і т.д.).

На думку І. Гальперіна, в публіцистичному стилі є два різновиди: а) стиль газетних повідомлень, заголовків й об'яв, які й складають суть газетного стилю; б) стиль газетних статей, які складають різновид публіцистичного стилю, куди також входять ораторський і стиль есе [2, с. 383-405].

Публіцистичний жанр газетного стилю активно взаємодіє 3 іншими функціональними стилями, використовуючи їхні прагматичні засоби і прийоми. У ньому, за словами Б. Вуайена, спостерігається «змішування розмовної мови, щоб бути зрозумілим, наукового стилю, щоб бути точним, художнього, щоб справити враження».

Вплив на читача (переконання, полеміка, агітація, пропаганда) вимагає широкого використання експресивних мовних засобів. Якщо в художній літературі експресивність носить індивідуально-образний характер і має на меті емоційний і естетичний вплив 
на читача, то експресивність у газетній публіцистиці служить завданню впливати на маси з метою спонукання їх до активних дій, а також формування суспільної думки.

Основу мови газетно-публіцистичного стилю складає книжково-повсякденна лексика, що являє собою поєднання елементів лексики і синтаксичних структур різних стилів. Але треба зазначити, що при цьому частково зберігається чи втрачається стилістичне забарвлення. Книжковий характер мови газетного стилю визначається тим, що він виражає цілісну інформацію, заздалегідь продуману та організовану.

Мова журнальних статей суспільно-політичних журналів майже не відрізняється від газетних статей. В них ще в більшому ступені, ніж в газетних статтях, з'являються літературно-книжкові раритети, неологізми (навіть такі, котрі потребують пояснення в тексті), вставні речення, звична образна фразеологія і інші компоненти публіцистичного стилю [2, с. 408].

Широке використання в газетно-інформаційному стилі імен та назв робить повідомлення конкретним і співвідносить дані відомості з певними особами, закладами чи районами. Це передбачає значні попередні (фонові) знання у Рецептора, які допомагають йому пов'язати назву з об'єктом, що називають.

Назви та імена досить часто використовуються в газетно-інформаційних матеріалах у скороченій формі. Часто ці скорочення можуть бути невідомими широкому колу читачів і їх значення тут же розшифровуються. Але існує багато таких скорочених назв, до яких читачі газети давно звикли, i тому їх не потрібно тлумачити. Велика кількість таких скорочень - це характерна риса газетно-інформаційного стилю сучасної англійської мови.

Сюди належать:

- назви партій, різних організацій та посад: ILM = Industrial Light \& Magic (кінокомпанія, що створює цифрові та звукові ефекти);

- прізвища відомих політичних діячів культури: $R L S=$ Robert Louis Stevenson, JFK = John Fitzgerald Kennedy;

- географічні назви: NJ. = New Jersey; SF = San Francisco.
Подібні скорочення зустрічаються у газетних текстах, незалежно від їх тематики.

За своєю структурою і засобом створення неологізми в мові газети та журналу представлені декількома варіантами. Найбільш характерними засобами створення неологізмів в мові англійської газети та журналу являється словотворення:

- Словоскладання - як тип словотворення представляє собою злиття двох або більш основ для створення нового слова. Для складних англійських слів найбільш частотними являються утворення, які складаються 3 двох основ. В останній час в мові англійських і особливо американських газет та журналів з'явилося безліч іменників, які утворені по конверсії засобом словоскладання iз сполучення дієслова і прислівника. В деяких спостерігається чітка повторюваність другого компоненту, яка в ряді випадків надає підставу вважати, що намічається визначена залежність між моделлю і iï значенням. Тому часто можна прогнозувати значення кожного нового у створеного за даною моделлю слова. (Stay-in - пікетування, Ride-in - протест проти дискримінації в ставленні до проїзду негрів в автобусах, Sit-in - сидячий страйк, OVER: Take-over - захоплення влади, Switch-over - перехід (на іншу тему), Push-over - легко переборна перешкода, OUT: Dropout - юнак, який кинув вчитися, Lay-out - людина, яка втратила роботу;

- Афіксація (brinkmanship, craffmanship, oneumanship, showmanship, bangdom, bogdom, suckerdom, factionalize - вигадувати; itemize - розглядати по пунктам; leonize - виходити у відкритий космос (утворено від прізвища космонавта А. А. Леонова); institutionalize - узаконювати, anti-apartheid, anti-fascist, pre-capitalist, pre-election.);

- Конверсія - перехід із одної частини мови в другу, що приводить до створення нового слова без змінювання його початкової форми. Це ще одне джерело неологізмів в англійської мові. Створені по конверсії, вони широко поширені в газетній лексиці. Висока частотність слів, створених по конверсії - одна із відмітних рис газетного стилю. 
Найчастіше це дієслова, які створені від іменників, і іменники, створені від дієслів. Доречно відмітити, що в знов створенім слові нерідко розвиваються значення; лише непрямо пов'язані зі словом-основою. Наприклад, в парі to hit - a hit; можна спостерігати цікавий розвиток значення в іменнику. В результаті цілого ряду переносів і переосмислене значення a hit стало означати успіх або то, що має успіх:

- Скорочення - велика кількість скорочуваних слів, особливо часто зустрічаються в заголовках - характерна риса мови газети та журналу. Абревіатура, тобто скорочення слів до одної літери, вимовляється за літерами: HO - Home Office; UNESCO - United Nations Educational, Scientific and Cultural Organization; WHO World Health Organization; NASA - National Aeronautics and Space Administration. Як правило, таки скорочення, що давно використовуються, не пояснюються в тексті;

Запозичення із інших мов («Wray buys pizza slice» (The Times, 17.07.2016), "Dangerous vodka and zakuski» (The Moscow Tribune, 25.02.2017), "Basic training in a babushka boot camp» (Kiev Post, 6-12.02.16); та велика кількість інтернаціональних слів: «Bush Vs. Kerry: Suiting up for a nasty brawl» (Advertising Age, 08.03.2004). Також існує багато запозичень у політичній сфері, наприклад: Franquista- послідовник політики іспанського диктатора Франко (iсп.) - brigatisti[bri:ga:ti:sti:] - члени терористичної організації «Червоні бригади» (італ.) - (Al)fatah - найбільша партизанська група організації визволення Палестини, - ayatollah (з арабської) - релігійний вождь ісламської секти Shгite в Ірані (слово стало відомим з січня 1979 року, коли після скидання шаха Ірану до влади прийшов Аятолла Хомейні) [3, с. 2-3].

Проводить спостереження над утворенням і причинами появлення неологізмів філолог Градобик. Він виділяє наступні морфологічні засоби утворення неологізмів за допомогою суфіксів: -ish, -y, -ese, -thon, -holic. Workaholic, bookaholic, chocaholic, drinkahilic, milkaholic, carollerthon, swimmerthon, mawkish, ploddy, housewifey.

$€$ інші способи утворення нових слів, наприклад слівкомпозитів, які пишуться через дефіс: tip-and-run (business), from rags-to-riches (topics), nitty-gritty (questions) та інші.
Що стосується фразеології, то газетно-інформаційний стиль визначається широким використанням готових формул або кліше. Тут виділяються численні вставні звороти, що вказують на джерело інформації (it is reported, it is claimed, according to wellinformed resources; оголошено, повідомляють), стійкі словосполучення із стертою образністю (to set the tone, to throw light, to gave the lie).

3 лексико-фразеологічних особливостей газети потрібно відмітити заміну простого дієслова стійким поєднанням, що додає в кожне речення зайві склади і створює враження великої плавності: render imperative, militate against, make contact with, take effect, serve the purpose of, etc. В таких поєднаннях частіше всього, беруть участь дієслова з широкою семантикою, такі, як: prove, render, serve, form, play, що поєднуються з абстрактними іменниками і прикметниками. Вони використовуються часто в пасивній формі: greatly to be desired, a development to be expected, brought to a satisfactory conclusion [1, c. 81].

Граматична своєрідність мови газети в інформаційному стилі досліджена В. Наером. Він відзначає своєрідність у використанні часів та станів, часте вживання не особових форм, численність складних атрибутивних утворень, особливі форми введення прямої мови та перетворення прямої мови на непряму, а також особливості у порядку слів і широке використання складнопідрядних речень.

Так, наприклад, цей дослідник звертає увагу на місце обставин певного часу не на початку та не в кінці речення, як звичайно, а між підметом і присудком, що своєю незвичайністю концентрує увагу на присудку. Сама обставина часу при цьому не має основного значення, вона несуттєва, оскільки газетна інформація, як правило, описує події, що відбулися напередодні. Якщо в реченні $€$ декілька різних обставин, то обставина часу за правилами граматики, повинна бути на останньому місці. Але у газетних повідомленнях цей порядок часто порушується, так як інформацію несуть більше обставини місця, а не часу; обставини місця виражаються зворотами із декількох слів та стоять в кінці речення $[1$, c. 82$]$. 
Отже, проаналізувавши лексико-стилістичні особливості газетного та журнального стилів англомовної преси ми дійшли висновку, що стиль преси має в себе спільні риси з художнім, розмовним,науковим стилями, а також має свої особливі ознаки.

\section{Література:}

1. Арнольд И. В. Стилистика современного английского языка. (Стилистика декодирования). Учебное пособие для студентов фак. и ин-тов иностр. яз. - Ленинград: «Просвещение», 1973. - 303 с.

2. Гальперин И. Р. Очерки по стилистике английского языка «Литература на иностранных языках», - 1958. - 460 с.

3. Мустафаєва К. В. Використання мовних ресурсів для створення мовної експресії у заголовках (на матеріалі англомовної та німецькомовної преси). - ресурс для перегляду www.studentam.net.ua

\section{Гаталяк Марта}

(м. Острог, Украӥна)

Національний університет «Острозька академія»

\section{БЛОГОСФЕРА ТА ОСОБЛИВОСТІ, ЕТАПИ РОЗВИТКУ БЛОГУ}

Тези присвячено огляду блогосфери як частини комунікативного простору, особливостей сучасного блогу як популярного комунікативного феномену, його етапи розвитку. Крім того, коротко розглянуто основні характеристики, типи блогів та їх особливості на лексичному рівні.

Ключові слова: блогосфера, блог, комунікативна компетенція, онлайн-щоденник, блогові інструменти.

Тезисы посвящены обзору блогосферы как части коммуникативного пространства, особенностей современного блога как популяного коммуникативного феномена, его этапь развития. Кроме того, кратко рассмотрено основные характеристики, типь блогов и их особенности на лексическом уровне.

Ключевые слова: блогосфера, блог, коммуникативная компетенция, онлайн-дневник, блог-инструментьл.

Abstract is devoted to review blogosphere as part of the communicative area, features of the modern blog as a popular communicative phenomenon, its stages of development. In addition, there are briefly described the main characteristics, types of blogs and their peculiarities on the lexical level.

Key words: blogosphere, blog, communicative competence, online diary, blogging tools.

Сьогодні вже незаперечним фактом є те, що інтернет - найколосальніше джерело інформації, який знало людство. Але його можливості, такі, як оперативність, швидкість і доступність зв’язку між користувачами на далеких і близьких відстанях, до- 
зволяють використовувати інтернет не тільки як інструмент для пізнання, але і як інструмент для комунікації

Комунікативна компетенція у всесвітній мережі стає однією 3 ключових цілей вивчення іноземної мови. Формування комунікативної компетентності - це готовність здійснювати іншомовне міжособистісне і міжкультурне спілкування як усно, так і письмово. Грамотне використання дидактичних властивостей і функцій різних сучасних сервісів мережі Інтернет дозволяють створити природне мовне середовище, формує внутрішню мотивацію до використання іноземної мови як засобу спілкування. Одним 3 найбільш популярних таких сервісів є блог, який має різні особливості, тому постала потреба їх глибшого вивчення.

Поняття «блог» (частина від виразу «weblog») це дискусійний або інформаційний веб-сайт, опублікований в мережі Інтернет, що складається 3 дискретних, часто неформальних текстових записів у стилі щоденника («постів», «повідомлення»), який підтримується індивідуумом. Блоги функціонують в спільній системі, яку називають блогосферою (від англ. blogosphere). Блогосфера, як частина комунікативного простору, характеризується низкою специфічних рис, таких, як глобальність і демократизм: розмиті межі форм спілкування (відсутність чітких політичних, державних, економічних, соціальних і вікових обмежень) створюють можливості для включеності користувачів зі всього світу, міжкультурної, масової та міжособистісної комунікації. Визначена М. Кастельсом як простір для розгортання суспільних практик [2]. Блогосфера характеризується демократичністю, що проявляється у відкритій для всіх учасників спілкування можливості впливу на суспільну думку. Дослідниця Зернецька Л. називає блогосферу «віртуальною громадською ареною початку XXI ст.». Зростання залученості аудиторії до процесу виробництва та медіації контенту надає їй нових якостей, що дає змогу назвати сучасних користувачів просьюмерами (від producer - виробник $\mathrm{i}$ consumer - споживач) [4, с. 14-24].

Сучасний блог розвинувся 3 онлайн-щоденника, де люди могли вести облік подій у своєму особистому житті. Більшість таких письменників називали себе «diarists», «journalists» або «journalers». Джастін Холл, який почав персональний блог у 1994 році, будучи студентом в Swarthmore College визнаний одним 3 найстарших блогерів, як і Джері Пюренле. «Scripting News» Дейва Вінера також зараховується до одних із старших і довше існуючих блогів [6].

В 1999 році блоги почали швидко завойовувати популярність, завдяки появі перших блогових інструментів. Брюс Абльсон запустив «Open Diary» у жовтні 1998 року, який налічував до тисячі онлайнових щоденників. Його інновацією стало опублікувавання коментаря читача, завдяки цьому Open Diary став місцем, де читачі могли додавати коментарі до записів блогів інших письменників. Бред Фіцпатрик запустив LiveJournal в березні 1999 року. Ендрю Смалес створив Pitas.com у липні 1999 року як просту альтернативу збереженню «сторінки новин» на веб-сайті, а потім «DiaryLand» у вересні 1999 року, зосереджуючись більше на спільнотах, які пишуть в стилі «особистого щоденника». Еван Вільямс і Мег Гуріхан (Pyra Labs) запустили Blogger.com у серпні 1999 року (придбаний компанією Google у лютому 2003 року). До 2004 року роль блогів стала ще важливішою, оскільки політичні консультанти, інформаційні служби та кандидати почали використовувати їх як інструменти для формування громадської думки та формування думок. Блоги було створено політиками та політичними кандидатами, щоб висловити свою думку про війну та інші питання та закріпити роль блогів як джерела новин.

Дослідниця О. Лутовінова, враховуючи стиль і жанр блогів виділяє 4 групи: 1) ті, що описують реальне життя і переживання автора, 2) щоденник-альбом/ блокнот, що збирає посилання, цитати, вірші і т.д., 3) щоденник-проект для популяризації відомої особистості чи проведення певних досліджень, 4) щоденникспільнота, що ведеться багатьма авторами і схожий на форум [3, с. 206-207]. Говорячи про основні характеристики блогу дослідниця Р. Блад виокремлює: часте поновлення, значну кількість посилань та високий рівень соціальної інтерактивності. Дослідниця виділяє три типи блогів: фільтри, щоденники та записні книги [5]. 
На думку І. Артамонової та К. Пилепенко, у блогах спостерігається поєднання і змішування стилів фамільярних (у постах адресованих потенційно великій аудиторії) та інтимних (у коментарях та відповідях на коментарі, призначених певному адресату) [1]. Тексти блогів є авторськими творами, які містять суб' єктивне бачення і насичені експресивними засобами, вибір яких на усіх рівнях мови залежить від жанру блогу та сфери функціонування.

Розглядаючи блоги на лексичному рівні, можемо зробити висновок, що вони вирізняються оцінною та розмовною лексикою, фразеологізмами, мовними кліше, стійкими сполуками, вживанням термінів залежно від тематичного спрямування блогу, містить скорочення та відхилення від мовних норм. Розмовна лексика, сленг, жаргонізми, просторіччя, вульгаризми, вигуки, слова 3 емоційно-експресивною конотацією, стилістичні засоби (метафора, метонімія, порівняння, евфемізм) слугують маркерами емоційності текстів блогів.

\section{Література:}

1. Артамонова I. М., Пилипенко К. О. Блог-записи як жанр інтернет-комунікації/І.М. Артамонова, К. О. Пилипенко // Світ соціальних комунікацій: наук.журн. - Том 1. - Київ : КиМУ, ДонНУ, 2011. - C. 16-19.

2. Етлінг Б. Публічний дискурс в російскій блогосфері / Б. Этлінг, К. Алексанян, Д. Келлі [та ін.] // The Berkman Center for Internet \& Society at Harvard University. $-2010 .-60$ p.

3. Лутовінова О. В. Лінгвокультурні характеристики віртуального дискурсу / О. В. Лутовінова. - Волгоград : Вид-во ВГПУ «Перемена», 2009. -477 c.

4. Castells M. The New Public Sphere: Global Civil Society, Communication Networks, and Global Governance / M. Castells // The ANNALS of the American Academy of Political and Social Science, 2008, Vol. 616, No. 1, P. 78-93.

5. Blood R. Weblogs: A History and Perspective [Електронний pecypc] /R.Blood// Rebeca's Pocket.-2000. - Режим доступу: http://www. rebeccablood.net/ essays/weblog_history.html

\section{Герасимчук Валентина}

(м. Острог, Україна)

Національний університет «Острозька академія»

\section{МОВНИЙ ПОРТРЕТ ЧАРЛІ ГОРДОНА}

\section{У TBOPI «FLOWERS FOR ALGERNON» BY DANIEL KEYES}

У статті розглядаються особливості мови дорослого Чарлі Гордона. В силу спеиифічності жанрової форми роману «Fowers for Algernon» by Daniel Keyes, основна увага приділяється дослідженню двох основних форм мови - усної письмової.

Ключові слова: мова, особливості мови, усна форма мови, письмова форма мови, мовний портрет, діалогічна мова, монологічна мова.

В статье рассматриваются особенности речи взрослого Чарли Гордона. В силу специифичности жанровой формы романа «Fowers for Algernon» by Daniel Keyes, основное внимание уделяется исследованию двух основных форм речи - устной и письменной.

Ключевые слова: речь, особенности речи, устная форма речи, письменная форма речи, речевой портрет, диалогическая речь, монологическая речь.

The article deals with the figures of Charlie Gordon's speech. Due to the specific character of the genre of the novel «Fowers for Algernon» by Daniel Keyes, the main attention is focused on the study of two basic forms of speech - oral and written.

Key words: speech, speech features, verbal form of speech, written form of speech, speech portrait, dialogical speech, monologue speech.

Мета дослідження полягає у вивченні функціонування лексичних та стилістичних засобів в якості смислоорганізуючого 
компоненту образу персонажа, що дозволяє побачити особливості мови Чарлі у творі.

Розповідь в романі «Квіти для Елджернона» є дорученою, тобто автор передає розповідь в руки персонажа для створення справжності описуваного. Персонаж, будучи елементом естетичного цілого, є носієм певної авторської ідеї, яка простежується в його промові.

Мова людини досить різноманітна. Традиційно, кажучи про мову персонажа, розглядають його зовнішню і внутрішню мову. Однак в силу специфічності жанрової форми роману, коли персонаж не тільки говорить і мислить, а й пише, що є проявом зовнішньої мови, правомірно відштовхуватися від двох основних форм мови - усної і письмової.

Говорячи про мову персонажа в рамках даної роботи, під усним мовленням персонажа будемо розуміти ті висловлювання, які персонаж виголосив вголос, тобто мова зовнішня озвучена. Під письмовою мовою, відповідно, будемо розуміти сукупність висловлювань персонажа - написаних, але не виголошених.

Основним видом усного мовлення є діалогічна мова, яка у психологічному плані найбільш проста, так як підтримується співрозмовником, часто не вимагає розгорнутого вираження думки. В цьому відношенні мова монологічна є більш складною. Вона вимагає від мовця вміння послідовно викладати свої думки $[3$, c. 260$]$.

Розглянемо особливості усного та писемного мовлення персонажа. Всі репліки одного персонажа в діалогах літературного твору складають його мовну партію. У романі «Квіти для Елджернона» було виявлено 78 діалогів, які є втіленням усного мовлення персонажа [4, с. 348].

Слід зазначити, що кількість діалогів з розвитком сюжету скорочується. Відповідно до пір року їх розташування наступне: 42 -23 - 13. При цьому діалоги в весняний і осінній період часто зводяться лише до кількох реплік Чарлі, в той час як влітку діалоги значно розширюються, кожен з яких, часом займає кілька сторінок. Отже, обсяг діалогів свідчить про інтелектуальний розвиток персонажа - 3 підвищенням рівня інтелекту зростає його здатність підтримувати розмову; а кількість діалогів свідчить про емоційний стан персонажа, його бажанні вступати в контакт 3 навколишнім світом.

Цікавою особливістю є те, що для передачі усної зовнішньої мови персонажа в центральній частині розповіді автором використовується пряма мова, на відміну від початку і кінця роману, де спостерігається змішання непрямої і неправильно оформленої прямої мови, тісно вплетене в розповідь.

Пряма мова індивідуалізує персонажа, в той час як непряма служить лише джерелом передачі інформації і засобом розгортання сюжету. Розглянемо діалог Чарлі з одним з лаборантів:

"So Burt sed Charlie what do you see on this card. I saw the spilld ink and I was very skared even tho I got my rabits foot in my pockit because when I was a kid I always faled tests in school and I spilld ink to.

(1) I tolld Burt I saw ink spilld on a wite card. Burt said yes and he smild and that maid me feel good. He kept terning all the cards and (2) I tolld him somebody spilld ink on all of them red and black. I thot that was a easy test but when I got up to go Burt stoppd me and said now sit down Charlie we are not thru yet. Theres more we got to do with these cards. I dint understand about it but I remembir Dr Strauss said do anything the testor telld me even if it dont make no sense because thats testing.

I dont remembir so good what Burt said but I remembir he wantid me to say what was in the ink. I dint see nothing in the ink but Burt sed there was picturs there. I coudnt see no picturs. I reely tryed to see. I holded the card up close and then far away. Then (3) I said if I had my eye glassis I coud probaly see better I usully only ware my eye-glassis in the movies or to watch TV but (4) I sed maybe they will help me see the picturs in the ink. I put them on and (5) I said now let me see the card agan I bet I find it now.

I tryed hard but I still coudnt find the picturs I only saw the ink. (6) I tolld Burt mabey I need new glassis. He rote somthing down on a paper and I got skared of faling the test. So (7) I tolld him it was a very nice pictur of ink with pritty points all around the eges but he shaked his head so that wasnt it neither. (8) I asked him if other pepul saw 
things in the ink and he sed yes they imagen picturs in the inkblot. He tolld me the ink on the card was calld inkblot.

Burt is very nice and he talks slow like Miss Kinnian dose in her class where I go to lern reeding for slow adults. He explaned me it was a raw shok test. He sed pepul see things in the ink. (9) I said show me where. He dint show me he just kept saying think imagen theres something on the card. (10) I tolld him I imaggen a inkblot. He shaked his head so that wasnt rite eather. He said what does it remind you of pretend its something. I closd my eyes for a long time to pretend and then (11) I said I pretend a bottel of ink spilld all over a wite card. And thats when the point on his pencel broke and then we got up and went out.

I dont think I passd the raw shok test» [8, c. 52].

3 одинадцяти реплік персонажа лише дві, під номерами 1 і 8 , $€$ безпосереднім втіленням непрямої мови. Фактично, в інших репліках персонаж передає слова в такому вигляді, в якому вони були їм вимовлені, тобто перед нами представлена пряма мова, що індивідуалізує персонажа. Однак, єдинопочаток I said, I told, a також відсутність належної пунктуаційної оформленості прямої мови порушують мелодійність діалогічного мовлення, розривають послідовність діалогу, тим самим позбавляючи його динамічності та емоційності. Досягненню того ж ефекту сприяє і саме вживання дієслів to say, to tell - хоча послідовне використання даних дієслів $є$ типовим для діалогів англійської мови, ніж багаторазове повторення «сказав» для української мови, їх надмірність надає промови персонажа ефект простоти, дитячості, інфантилізму, що безсумнівно бере участь в створенні образу персонажа.

Підтвердження тих же ідей ми знаходимо на різних рівнях мови, які завжди так чи інакше підпорядковані ідейному задуму автора і вираженню художнього змісту, тобто кожен елемент тексту імпліцитно або експліцитно відображає естетичний зміст твору [1, с. 240].

Головною особливістю мови персонажа в романі «Квіти для Елджернона» є iї неоднорідність, що свідчить про нестабільність персонажа, його динамічний розвиток.
Так, лексичне наповнення промови персонажа, іiі синтаксична оформленість безперечно обумовлені ситуацією спілкування, темою діалогу, але в той же час залежать і від особистості мовця [6, c. 170].

Співвідношення різних пластів лексики і граматики пояснюється приналежністю до тієї чи іншої композиційної частини твору: персонаж до операції, після неї і після регресії.

Мова Чарлі на початку і кінці роману не наповнена складними лексичними одиницями, навпаки, в ній присутні типові для розмовної мови скорочення і розмовні слова:

"I told him thanks doc you wont be sorry for giving me my 2nd chanse like Miss Kinnian says» [8, c. 52].

"I askd Prof Nemur if I coud beet Algernon in the race after the operashun» (Keyes D. Flowers for Algernon. P. 9).

«I said hi doc Im skared» [8, c. 52].

"I tolld him because all my life I wantid to be smart and not dumb and my mom always tolld me to try and lern just like Miss Kinnian tells me but its very hard to be smart and even when I lern something in Miss Kinnians class at the school I ferget alot» [8, c. 52].

"I said thats what Miss Kinnian tolld me but I dont even care if it herts or anything because Im strong and I will werk hard» [8, c. 52]. «Boy I said thats a smart mouse» [8, c. 52].

"I said so what am I gonna do» [8, c. 52].

До ознак, кваліфікуючи освітній і соціальний статус персонажа, ми віднесемо використання двох негативних форм при одній суб' єктно-предикативній парі, використання однієї універсальної стягнутої форми is not замість будь-якого допоміжного дієслова або дієслова-зв'язки, do not в третій особі однини. Наприклад:

"I said I dint care because I aint afraid of nothing» [8, c. 52].

"I told him nothing speshul ever happins to me and it dont look like this speshul experimint is going to happin neither» [8, c. 52].

«I meen I pretend to pepul I know how to read but it aint true and I wantid to lern» [7, c. 75].

Лексико-граматичні порушення мови, зазначені вище, зникають в мові персонажа по ходу розповіді, що свідчить про збільшення його інтелекту, і знову з'являються в кінці роману. 
Слід зазначити наявність вульгаризмів, що з'являються в мові персонажа на піку його розвитку:

«But it's more than liking. What I mean is... oh hell! I don't know what I mean» [8, c. 52].

«You're damned right, something is happening!» [8, c. 52].

«I will be... in a minute... Just that damned buzzing in my ears» $[8$, c. 52].

Таким чином, контраст мови простої і ускладненої дозволяє зробити висновки про зміну рівня освіченості персонажа. Однак, наявність вульгаризмів в серцевині роману і їх повна відсутність на початку і в кінці, що було б типовим для людини неосвіченої, дозволяють зробити висновки про те, що мова персонажа на початку і в кінці роману не стільки мова людини неосвіченої, що, безумовно, має місце, скільки мова, схожа на дитячу.

Важливим стилістичним прийомом, що характеризує Чарлі, $є$ повтор однієї репліки двічі в романі. Персонажа в дитинстві ми бачимо практично позбавленим мови, мовчазним, за винятком рідкісних реплік. Переляканий Чарлі на прийомі у лікаря кричить:

«Maaaa!»

«She's outside. Don't worry, Charlie. This won't hurt a bit.»

«Want Ma!»Charlie is confused at being restrained this way» $[8$, c. 52].

Пізніше ми зустрічаємо цю репліку, коли Чарлі приходить до матері після довгих років розлуки. Слід зазначити, що до того моменту мова Чарлі нормалізувалася і була абсолютно грамотною.

Виділення мовностилістичних маркерів мовного портрета персонажа дозволило зробити висновок про те, що мовна характеристика персонажа займає чільне місце в структурі його образу і включає різноманіття характеристик, які передають читачеві нову інформацію про світ, і в той же час - ставлення до неї

\section{Література:}

1. Єфімов Л. П. Стилістика англійської мови і дискурсивний аналіз. Учбово-методичний посібник / Л. П. Єфімов, О. А. Ясінецька. Вінниця: Нова книга, 2004. - 240 с.

2. Кіз Д. Квіти для Елджернона / Д. Кіз. - Харків: Книжковий клуб «Клуб Сімейного Дозвілля», 2015. - 304 с.
3. Колокольцева Т. Н. Специфические коммуникативные единицы диалогической речи / Татьяна Николаевна Колокольцева. - Волгоград: Изд-во Волгоградского гос. Ун-та, 2001. - 260 с.

4. Кусько Є. Я. Лексико-синтаксичні засоби мовної характеристики персонажів у романах / Є. Я. Кусько; Лвівський держ. ун-т. - Львів, 1969. $-348 \mathrm{c.}$

5. Ли Д. Ю. Особенности перевода полуотмеченных структур и отклонений от литературной нормы в поэтическом тексте / Д. Ю. Ли // Международный студенческий научный вестник. - 2015. - № 5. Часть 1. - С. 77-79.

6. Мартиненко Т. I. Діалогічна єдність: структурно-семантичний і комунікативно-прагматичний аспекти - Вінниця: Нова книга, 2005. $-170 \mathrm{c}$.

7. Keyes D. Flowers for Algernon / D. Keyes. - London : Orion, 2000. $-224 \mathrm{p}$.

8. Keyes Daniel. Algernon, Charlie and I: A Writer's Journey. / Daniel Keyes. - Boca Raton, FL: Challenge Press, 1999. - 223 p. 
УДК $81 ’ 255$

\section{Іванішина Наталія}

(м. Острог, Украӥна)

Національний університет «Острозька академія»

\section{ВЕРБАЛІЗАЦІЯ ВВІЧЛИВОСТІ У МОВАХ ОРИГІНАЛУ ТА ПЕРЕКЛАДУ}

У тезах було представлено характерні особливості категорії «ввічливість» та з'ясовано, щьо вона є однією з головних категорій у комунікаиї людей та у структурі етикетно-мовного спілкування.Також роботі було систематизовано засоби для вираження позитивного, ввічливого ставлення до свого співрозмовника. Вони включають як лексичні так і граматичні маркери демонстрування ввічливості: емоиійно-забарвлені слова, метакомунікативні одиниці перебільшення, модальні фрази, модальні частки, ввічливі конструкції при звертаннях, розділові запитання та ін.

Ключові слова: ввічливість, позитивна та негативна ввічливість, етикет, комунікація.

В тезисах были представлены характерные особенности категории «вежливость» и выяснено, что она являет ся одной из главных категорий в коммуникачии людей и структуре этикетных-мовногоспилкування.Також работе были систематизированы средства для выражения положительного, вежливого отношения к своему собеседнику. Они включают как лексические так и грамматические маркеры демонстрации вежливости: эмоционально-окрашенные слова, метакомуникативни единииы преувеличения, модальные фразы, модальные частииы, вежливые конструкиии при обрамениях, разделительные вопросы и др.

Ключевые слова: вежливость, положительная и отрицательная вежливость, этикет, коммуникация.

The research presented the characteristic features of the category of «politeness» and found that it is one of the main categories in the communication of people and in the structure of etiquette- languagecommunication. Also, the work was systematized means for expressing a positive, polite attitude to his interlocutor. They include both lexical and grammatical markers of display of courtesy: emotionally-colored words, meta-communicative exaggeration units, modal phrases, modal particles, polite design at appeals, separation questions, etc.

Key words: politeness, positive and negative politeness, etiquette, communication.

Міжособистісне спілкування є невід'ємною частиною життєдіяльності людини, важливим елементом якого є саме вміння вести бесіду. Попри все бажання досягти бажаного результату комунікації - це неможливо це застосування стратегій ввічливості. Адже вони саме демонструють високий рівень мовного етикету особи. Лише за умови володіння необхідними стратегіями, людина зможе належним чином оформити свій комунікативний намір та бути почутою співрозмовником.

Вербалізація ввічливості знаходить своє відображення в різних типах дискурсивної діяльності людини. Тому недарма вона стала предметом досліджень багатьох вчених: E. Goffman, P. Brown, S. Levinson, G. N. Leech G. та інші. Вітчизняними вченими, які працювали у цьому напрямку є Г. Г. Почепцов, В. I. Карасик, Ю. М. Лотман, А. С. Гафарова, Т. В. Ларі

Робота присвячена дослідженню вербалізації категорії ввічливості, їі стратегій, засобів вираження в англійській та українських мовах. Актуальність теми роботи зумовлюється зростанням інтересу до ролі мовного етикету в міжособистісному спілкуванні, зокрема до категорії ввічливості; сутністю в україністиці системного та комплексного вивчення цієї категорії.

Мета дослідження полягає у 3'ясуванні поняття категорії «ввічливість», аналізі тактик вербалізації ввічливості в порівнюваних умовах, вивченні основних засобів ії реалізації.

Об'сктом дослідження виступає категорія ввічливості в мовах оригіналу та перекладу. Предметом дослідження є засоби та особливості вербалізації стратегій, тактик позитивної та негативної ввічливості, за допомогою яких вона реалізується у порівнювальних умовах. 
У процесі спілкування кожен з учасників намагається зацікавити партнера, привернути його увагу, змусити співпереживати. Саме ввічлива функція мовлення має велике значення для успішної комунікації та проявляється у повазі до співрозмовника.

Категорія ввічливості становить великий інтерес у сфері прагматики. Вона розглядається як набір стратегій або мовленнєвих моделей, які встановлюється одними комуні кантами як норми для себе, або іншими - я норми для них, і водночас як соціально зумовлені поведінкові норми, вербальні і невербальні, у визначеній суспільній групі [7, с. 77].

А. Безсонова дає визначення поняттю «категорія ввічливості» як функціонально-семантична категорія, план змісту якої визначають семантичні компоненти ввічливого спілкування (повага, доброзичливість до співрозмовника, паритетністю комуні кантів тощо), а план вираження різнорівневі мовні одиниці, що служать для їі репрезентації [1, с. 177].

Для успішно ввічливості комунікації потрібно застосувати певні принципи, стратегії ведення розмови Р. Лакафф формує узагальнені принципи ввічливості. Вони зводяться до 3-х найголовніших:

- Не нав’язуй свою думку (Do not impose);

- Давай співрозмовнику можливість вибору (Give opinions);

- Будь доброзичливим (Make the listener feel good. Be friendly) [4, c. 45]. Дійсно, ці правила можна вважати запорукою успішної комунікації. Але потрібно пам'ятати, що знати ці принципи в теорії недостатньо. Потрібно вміти ними оперувати.

I. Гофман, розуміє ввічливість у двох формах - формули вітання, прохання, звертання, подяки, вибачення тощо, які служать для посилення позитивного іміджу адресата, а з іншого - $\epsilon$ стратегією уникання неприємних для адресата тем, обмеження втручання в його приватну зону [6, с. 170].

Дуже часто ввічливість прирівнюють до етикету. Але ввічливість $є$ ширшою за етикет. Етикет становить собою зведення певних норм, правил, а ввічливістю це сукупністю певних стратегій, тактик, які використовуються при спілкуванні та спрямовані на взаєморозуміння та уникнення конфліктів. Варто погодитися 3 думкою Л. П. Крисіна, що основна мета використання етикетних моделей адресатом - це прагнення не створювати у співрозмовника відчуття комунікативного дискомфорту [7, с. 118].

Т. Ларіна виділяє три рівні ввічливості: високий, середній і низький. Високий рівень характерних для офіційного спілкування, середній для нейтрального стилю, а низький більш для розмовно-побутового спілкування [8, с. 36]. Інші ж науковці дотримуються універсального поділу ввічливості на позитивну (positive politness) і негативну (negative politeness). Кожен з цих які досягають мети ввічливого спілкування. Приклад наведемо із роману сучасної англійської письменниці Дж. Колган: Would you mind watching the phone while I go to the toilet?

У цьому випадку дівчина звертається до своєї подруги зі звичайним проханням. Але при цьому вона використовує питання із Would you mind, що перекладається як: Чи не могла б ти...Як бачимо дівчина висловлює не лише прохання, а й намір бути ввічливою.

Стратегії ввічливості також передбачають демонстрування уваги, розуміння, симпатії, співчуття до співрозмовника.

LadyHunstanton:(...)Andhowisyourbeautifulembroiderygoingon? Вираження ввічливості безпосередньо пов'язане з оцінкою соціального статусу особи. У плані статусно-оцінної поведінки ввічливістю представлена В.I. Карасиком у трикомпонентній структурі на опозиції ввічливе/неввічливе ставлення до партнерів спілкування:

1) позиція мовця (емоційно-вольовий самоконтроль, ступінь вольового контролю; рефлексія мовця - вектор самоповаги);

2) взаємозв'язок мовця й адресата (непередбачувана й фактична реакція партнера - вектор залежності)

3) спосіб мовного вираження [4, с. 86-87].

Ввічливе спілкування також передбачає дотримання певних обмежень до змісту питання. Звертаючись до старшого за віком або, наприклад, при далекій соціально-психологічній дистанції не варто ставити питання, що стосуються особистого життя співрозмовника, його віку, доходів та ін. Оскільки вашому співрозмовнику доведеться ухилятися від відповіді. Саме в таких си- 
туаціях слухачу найчастіше доводиться прибігати до ухильних відповідей, наприклад: 'Do you love him?' - asked Dorothy. 'It isn't a question of loving him'.- said Ursula [34]. У цьому випадку фраза it isn't a question of loving him, що перекладається, як: Питання не в тому, кохаю я його чи ні підкреслює небажання комуніканта відповідати на посталене запитання.

Власне структуру категорії ввічливості складають ієрархічно впорядковані норми. Вони включають в себе:

a) підтримання комунікативного контакту;

б) стриману манеру поведінки;

в) демонстрацію загальної культури мови;

г) традиції, а також закони і табу.

Ці норми відображують соціальні та культурні цінності, які, в свою чергу, є важливими для ввічливості. Треба також пам'ятати, що категорія ввічливості має ще й національно-культурну специфіку. Для кожної комунікативної культури притаманні свої рівні ввічливості. Перш за все це пов'язано з різними прийнятими моделями соціальної поведінки, маркерами вираження ввічливості (лексичними, граматичними, синтаксичними), структурами розбіжності мов, спеціальними етикетними формулами.

Основні положення теорії ввічливості представлені у роботах англійських дослідників П. Брауна та С. Левінсона. Ключовим концептом у їх теорії $є$ «FTA» (Face Threatening Act). Згідно з цією теорією, в основному ввічливості покладено поняття суспільного обличчя як самоповаги індивідів, з яким пов'язані бажання уникнути перешкод у своїх діях та бажати отримати схвалення своїх дій $[8$, с. 46]. Відповідно, ввічливість виявляється у взаємному бажанні захистити, зберегти «обличчя» обох партнерів мовленнєвої взаємодії. Ураховуючи цей важливий взаємозв'язок, будь - який учасник комунікації намагається уникати потенційних загроз, використовуючи при цьому різноманітні мовні стратегії. На основі цього виокремлюють позитивну та негативну ввічливість.

Дж. Ліч у своїй роботі «Principles of Pragmatics» зауважує, що негативна ввічливість (намагання уникнути суперечок, конфліктів) важливіша, ніж позитивна ввічливість (прагнення до згоди)
[9, с. 156]. Але стверджувати однозначно не можна. Оскільки іноді моделі позитивної ввічливості можуть виражати негативну.

Стратегії позитивної ввічливості пов'язані з демонстрацією єдності та солідарності мовця 3 тим, хто слухає. Вони проявляються у демонструванні уваги та інтересу до співрозмовника, прагнення до взаєморозуміння і злагоди 3 ним, врахування його бажань і схильностей.

Під негативною ввічливістю криється побоювання здатися навязливим, завдати шкоди адресату, відсутність емоцій, стриманість [2, с. 220]. Наприклад: I was wondering if you could help me to find here [36, с. 134]. У цьому реченні безпосередньо вказується на те, що мовець боїться зайвий раз потурбувати адресата. Порівняймо з українською мовою: - А не міг мені пан капітан сказати, чи не живе тут яка пані капітанова? Наведений приклад ще раз доводить, що для негативної ввічливості характерними ознаками $\epsilon$ мінімізація вторгнення, вираз ввічливого песимізму та ін.

Однією з головних стратегій негативної ввічливості є «говори прямо» (Be indirect). Наприклад, якщо ми хочемо щось запитати, то краще використовувати не пряме запитання, а більш увічливу форму - непрямого питання із супровідною іллокуцією прохання [9, с. 92]. Наприклад:

- Would you tell me, please, where the post office is?- Чи немогли б ви мені сказати, будь ласка, де знаходиться поштове відділення?

Головним чином комуніканти вдаються до стратегій негативної ввічливості у випадках вираження таких мовленнєвих дій, як незгода, негативна оцінка, звинувачення, відмова, вихваляння, заперечення.

Найбільш поширеними стратегіями позитивної ввічливості, як для англійської, так і для української мов, є прояв інтересу до потреб адресата, маркування групової приналежності шляхом використання жаргону, сленгу, використання жартівливих висловів, вираз компліментів. Пор.:

- You won't looking for another woman? - I'll look at other women to compare them to you, and know that you're the most beautiful woman in the world.- Я люблю тебе, Анно, вже віддавна! Ти така гарна й добра! 
Ще однією не менш важливою стратегією є комунікативна емотивність. Саме використання емоцій характерно для англійської ввічливості. Наприклад: Oh, my Lord! You are safe! Цей приклад $є$ проявом демонстрації позитивних емоцій, що є притаманними для англійської комунікативної поведінки. Варто зазначити, що українські еквіваленти вигуку Oh, my Lord! (Cлава Богу! $O$ Боже!) є особливо апритаманними українському художньому дискурсу та вживаються і різних комунікативних ситуаціях, наприклад: Слава Богу, ти прийшов!

Ввічливість $є$ також оцінкою адресанта себе як представника певної групи, соціуму, який дбає про збереження самоповаги. Взаємодіючи з учасниками спілкування, мовець, зазвичай, хоче отримати схвалення своїх і намагається усунути перешкоди, які виникають під час мовленнєвої діяльності [5, с. 47].

Таким чином, ввічливість $є$ невід'ємною складовою частиною міжкультурної комунікації. Маючи знання про те, що які стратегії ввічливості характерні для певної культури, в результаті можна досягти успішної комунікації. Саме ввічливість $є$ центральною комунікативною категорією. Вона регулює поведінку, забезпечує і організовує гармонійне спілкування.

Вміння оперувати принципами ввічливості допомагає запобігти помилок у міжкультурному спілкуванні, ефективніше взаємодіяти $з$ представниками інших культур. Ввічливість - це універсальна категорія, що передбачає використання певних стратегій, які забезпечують ефективну комунікацію. Так, позитивна ввічливість спрямована на зменшення комунікативної дистанції, досягнення взаєморозуміння. В свою чергу застосування стратегії негативної ввічливості сприяє зменшенню комунікативного тиску на співрозмовника, виникненню конфліктів, запобіганню комунікативним невдачам.

Мовець обирає позитивну стратегію, коли намагається бути ближчим до слухача, виявити інтерес, увагу до нього. Для цього він обирає емоційно-забарвлені слова, виражає компліменти та ін. Негативна стратегія ввічливості, навпаки, підкреслює бажання мовця соціально відсторонитися від співрозмовника.

\section{Література:}

1. Безноса А. П. Граматичні індикатори вираження ввічливості (3 історії вивчення питання) / П. А. Безноса // Лінгвістичні студії. - 2008. - № 17. - С. 176-180.

2. Вжещ Я. Л. Принцип ввічливості в теорії і практиці міжкультурної комунікації. Теорія збереження обличчя П. Брауна та С. Левінсона / Я. Л. Вжещ // Вісник ЛНУ імені Тараса Шевченка. Ч. ІІ. - 2011. - №9. - C. 251-255.

3. Карасик В. Язык социального статуса. Социолингвистический аспект. Прагмалингвистический аспект. Лингвосемантический аспект / В. Карасик. - Москва: Гнозис, 2002. - 333 с.

4. Крысин Л. П. Социолингвистические аспекты изучение современного русского языка / Л. П. Крысин. - Москва: Наука, 1989. - 186 с.

5. Ларина Т. В. Категория вежливости и стиль коммуникации: Сопоставление английских и русских лингво-культурных традиций / Т. В. Ларина. - Москва: Языки славянских культур, 2009. - 516 с.

6. Рогатюк А. Є., Рабійчук І. Л. Непрямі мовленнєві акти як форма реалізації негативної ввічливості у сучасній англійській мові / А. Є. Рогатюк, І. Л. Рабійчук // Науковий вісник Волинського національного університету імені Лесі Українки. Серія Комунікативна лінгвістика. Луцьк. - 2011. - № 4. - С. 92.

7. Формановская Н. И. Культура общения и речевой этикет / Н. И. Формановская // Русский язык в школе. 1993. - № 5. - С. 75-89. 8. Brown P., Levinson S. Politeness: Some Universals in Language Usage. - Cambridge: Cambridge University Press, 1987. - 345 p.

9. Leech G. N. Principles of Pragmatics G. N. Leech. - London: Longman, 1983. -250 p. 
сення якісних характеристик одного явища на інше є однією 3 iii фундаментальних властивостей. Це свідчить про необхідність застосування метафори у художньому творі для підсилення емоційного порогу, та загального рівня перцепції у суб єкта. Таким

\section{Іванова Ольга}

(м. Острог, Украӥна)

Національний університет «Острозька академія»

\section{ЛЕКСИКО-СЕМАНТИЧНИЙ АСПЕКТ КЛАСИФІКАЦІЇ МЕТАФОР}

Тези присвячено висвітленню сутності та змісту семантичної класифікації метафор в літературі на матеріалі англійської та украйнської мови. Проаналізовано підходи різних вчених щсодо класифікачії метафор за допоміжним суб 'єктом. Проаналізовано види метафор та їх застосування в англійській та украӥнській мовах.

Ключові слова: семантичний зсув, семантична інновачія, жива метафора, логіко-граматична основа, асоиіація.

Тезисы посвящено освещееню сущности и содержания семантической классификации метафор в литературе на материале английского и украинского языков. Проанализированы подходы различных ученых по классификации метафор за вспомогательным субъектом. Проанализированы виды метафор и их применение в английском и украинском языках.

Ключевые слова: семантический сдвиг, семантическая инновация, живая метафора, логико-грамматическая основа, ассочиачия.

The theses are devoted to the nature and content of the semantic classification of metaphors in the literature based on the data from Ukrainian and English languages. The approaches of various scientists to classify the metaphors according to the secondary subject are discussed. The metaphors typology and its implication in English and Ukrainian languages are analyzed.

Key words: semantic shift, semantic innovation, living metaphor, logical and grammatical basis, association.

Здатність мови застосовувати стилістичні прийоми, що грунтуються на принципі ідентифікації двох предметів та перене-

\footnotetext{
(с) Іванова Ольга, 2018
}

чином, метафора виконує гносеологічну функцію, характеризує предмети за аналогією із доступними предметами.

Для досконалого розуміння лексико-семантичної природи метафор, було проаналізовано низку праць 3 теорії мовознавства, що висвітлили основні властивості метафори, погляди від часів античності до постмодерну. Позицій лінгвістів щодо тропу безпосередньо вплинули на створення метафор такого типу, зокрема класифікація П. Вілрайта, Дж. Лакоффа та М. Джонсона.

Метафора уможливила правильне розуміння процесів мислення і побудови ментальних уявлень про світобудову. Тому найбільшого розвитку набула пізнавальна функція метафори, знайшовши своє відображення у працях багатьох мислителів, філософів та літературознавців.

Існує безліч теорій щодо походження тропа, проте Ю. Лотман зробив акцент на семантичну несумісність та неадекватність складових частин метафори. Тому їх симбіоз утворює потужний семантичний ефект, який і характеризує троп. Такий же результат від поєднання несумісних «сем» та ступеня семантичної віддаленості дослідник виділяє декілька несумісних ознак [2, с. 6-15]:

- Двомірність - багатомірність;

- Реальність - нереальність;

- Матеріальність - нематеріальність;

- Знаковість - не знаковість та ін.

«Семантична інновація» метафори за П. Рікером грунтується на присвоєнні логічним суб' єктам предикатів, що нездатні до поєднання. В основі теорії лежить матриця інтелігібельності, тобто пізнання за допомогою розвинутої продуктивної уяви. Тобто семантична інновація на рівні фрази утворює «живу метафору» [4, c. 311-323].

Протилежне бачення набуває метафоричний смисл за Рікьолєм, що становить загадку або семантичну колізію. Досягнути 
семантичної правильності можливо лише у межах категорії «бачити як», що є посередником між метафоричними аспектами.

Л. Булаховський писав про асоціації, від яких залежать зрушення значень існуючих слів: «Треба раз у раз враховувати, що значення не залишаються весь час у тій самій сфері почуттів, а легко переносяться за подібністю між змістом почуттів з однієї до другої сфери (гострий зір, гострий слух...) [4, с. 323-356].

М. Блек у праці «Моделі та метафори» дотримується точку зору, що в метафорі слова розділяються на дві групи: одні становлять частину так званої «рами», а інші несуть непрямий зміст або «фокус». Останній визначає контекст використаних виразів, поєднує лише деякі ознаки референтів, на основі аналогій чи асоціації. Це спричиняє «семантичний зсув», який змінює первинне смислове бачення виразу, розглядає його під новим кутом бачення [5, с. 95-126].

Ю. Апресян зробив акцент на ознаках метафори, які не становлять прямого значення тропа, а утворюють цілу низку виражених словом семантичних асоціацій [1, с. 122-216].

Метафора характеризується семантичною двоплановістю вжитого слова, тобто два значення слова, що застосовані в контексті активізуються одночасно: пряме і метафоричне. За цим можна провести семантичну диференціацію структури метафори на внутрішню та зовнішню.

В аспекті зовнішньої (номінативно-предметної) структури метафори відображено характер взаємозв'язку між явищами об'єктивної дійсності. У внутрішній метафорі досліджується механізм семантичної взаємодії її складових, у тому числі спільних та відмінних сем та компонентний склад метафори.

Існує багато типів класифікації метафори, серед яких за граматичними, структурними, морфологічними, семантичними характеристиками тощо.

Відповідно до семантичного значення визначають такі види метафор:

- Номінативна метафора - перенесення назви;

- Образна метафора - сприяє розвитку синонімічних засобів мови;
• Когнітивна метафора - утворюється в результаті перенесення значення;

- Генералізуюча метафора - згладжує в лексичному значенні слова межі між логічними порядками і слугує стимулом виникнення логічної полісемії.

Класифікацію метафоричних моделей запропонували Лакофф та Джонсон, за напрямком взаємодії сфера-джерело і сфера-мета $[3$, с. 67-153]:

- структурні метафори (structural metaphors) - один концепт метафорчино структурований в межах іншого: Argument is war.

- орієнтаційні метафори (orientational metaphors) - створюється система відповідності одних концептів до інших: I fell into a depression.

- онтологічні метафори (ontological metaphors) - ототожнення людського досвіду із матеріальними об'єктами чи речовинами: I get a lot of satisfaction out of washing windows.

Згідно теорії П. Вілрайта семантична класифікація повинна бути здійснена наступним чином [5, с. 126-300]:

- Класифікація заснована на асоціативних зв'язках між засобом вираження і якісною характеристикою, утворюючи основу для подібності: подібності функцій (the hands of the clock), подібність форми (a bottle's neck), схожість структури і речовини (а flood of tears), подібність результаті (he evaporated) і т.д.

- Класифікація заснована на логіко-граматичному значенні основи в метафорі, описуючи процес номінації в ній. Основа може описувати:

- Характеристика суті предмету через інші субстанції (в основі іменники): 'It (the sun) struck upon the hard sand and the rocks became furnaces of red heat' (V. Woolf).

- Характеристика суті предмету через дію (в основі дієслівні іменники): 'There was a stir and bustle among the stars' (S. Fitzgerald).

- Характеристика суті предмета через його властивості (в основі якісні іменники): 'From the desert to the east a thin crust of thunder formed like a scab upon the melodious silence' (L. Durrel).

- Характеристика дії через суть предмету (домінантні дієслова): 'They (the waves) serpented towards his feet' (J. Joyce). 
- Характеристика однієї дії через іншу (прості дієслова): 'Не watched him closely while he excavated his smile' (G. Greene).

- Характеристика дії через якість (дієслова, що утворюються через додавання суфіксів до прикметників): 'Mrs. Cloudesley Shove blackens the doorway with her widowhood' (A. Huxley).

- Характеристика якості через суть предмету (називних означень): 'Illige's complexion was sandy with them(freckles). Protectively coloured, the sandy-orange eyebrows and lashes disappeared . . . into the skin as a lion dissolves into the desert' (A. Huxley).

- Характеристика якості через дію (дієприкметник): 'Sometimes at night it had seemed to her as though no one lived here - they had all gone long ago - living lighted houses to be covered in time by tombing heaps of sleet' (S. Fitzgerald).

- Характеристика якості через іншу якість (базові прикметники): 'Вy day beside a livid sea, unbeheld, in violent night walking beneath a reign of uncouth stars' (J. Joyce).

Класифікація метафор базується на предметі засобу вираження, наприклад, частині людського або тваринного тіла чи притаманній для нього функції відповідно до якого метафори можуть бути антропоморфними, зооморфними чи рослинні і т.д. Деякі зразки подібної класифікації можна знайти у праці Мезеніна. Приклад антропоморфної метафори: 'Luck had kissed her hand to him' (O. Henry), 'the seaweed ... gave to us the murmuring shore' (A. Tate), зооморфні: 'a certain stilled inwardness lies coiled in her gaze' (A. Miller), 'the scorpions of absolute necessity' (A. Bennett), 'the next two hours tripped by on rosy wings' (О. Неnry), рослинні: 'Pluck from the memory a rooted sorrow'(W. Shakespeare).

Вивчення однієї і тієї ж або аналогічних засобів вираження метафор у різних прикладах може виявитися корисним для створення асоціативної гами понять, які вони позначають. Крім того, асоціативний потенціал сприяє віднаходженню однакових або аналогічних термінів, якщо здійснюється зворотний аналіз.

Класифікація метафор на основі конкретності / абстрактності терміну. Головне завдання метафори виключаючи сам термін налаштоване конкретно проти абстрактного поняття. Залежно від типу засобу вираження тропу, ми можемо говорити про конкрет- ні, наприклад, 'Down rippled the brown cascade (of hair)' і абстрактні метафори - 'The real will from its crude compoundings come' (W. Stevens). Вивчення метафори дало змогу розглянути способи зберігання знань, мовленнєвих процесів, організації внутрішнього лексикону та людської пам'яті.

Метафора завжди знаходиться в рамках певної лексичної групи, коли існує потреба номінативного позначення певних реалій. У кінцевому результаті семантичний процес зводиться до заміни одних дескриптивних значень іншими. Таємниця створення метафори привертала до себе найбільших мислителів - від Аристотеля до Руссо і Гегеля і далі до Е. Кассірера, Х. Ортеги-і-Гассета та багатьох інших. Арістотель визначав як «перенесення предмету з роду на вид або з виду на рід, або з виду на вид, або за аналогією» [8, с. 67-276]. Арістотель розцінював метафору передусім у симбіозі із проблемами поетичного мистецтва і риторики, а це відповідно підтверджує ідею метафори як засобу прикрашання, підвищеної виразності стилю, мовлення, через що і неодноразово підкреслював роль доречного застосування метафори у діяльності риторів та поетів.

Т. Гоббс та Г. В. Лейбніц не відкидають факту, що метафора широко застосовується у висловлюваннях теологів і пророківмістиків, проте переходячи до спектру «пошуків істини» і «суворої філософської мови», метафора набуває змісту «обману» i «безглуздя», «туман і темнота» [7, с. 143].

Нове визначення тропу в результаті багатьох досліджень подав Дж. Лакофф: перетинання ряду смислових галузей в концептуальній сфері. На позначення метафори за традиційним методом використовував поняття метафоричного виразу (слово, фразу або речення), що лише поверхнево реалізувало перетин смислових галузей. Незважаючи на розроблення нового бачення метафори у концептуальній сфері, основною метою Дж. Лакоффа було розроблення концептуальної теорії тропу [9, с. 98-453].

Таким чином, Дж. Лакофф доводить, що світопізнання неможливе без метафоричного мислення, адже уподібнення одного предмету до іншого лежить в першооснові утворення механізму 
нескінченого числа концептів, що в сукупності становлять гармонійну картину світу $[9$, с. 98-453].

Іншу позицію ролі метафори зайняв Ф. Ніцше, який значно переосмислив когнітивну функцію метафори, майже повністю поєднавши іiї із естетичною та експресивною як єдино правильну по відношенню до пізнавальної діяльності людини. Проте Ніцше тільки окреслює відношення речей до людей і для цього використовує найсміливіші метафори. Ми впевнені, що знаємо щось про самі речі, коли мова йде про дерева, фарби, дощ чи снігопад, а на справді ми володіємо лише метафоричним баченням речей, які абсолютно різняться від їх первісного значення [4, с. 384].

Філософ Девідсон висунув гіпотезу, що метафори цілком відносяться до сфери прагматики, області дії на інтерпретанта, а не до семантичного поля $[11$, с. $402-445]$.

Важливими і перспективними дослідженнями метафори як засобу пізнання стали спроби класифікації пізнавальних метафор. Так, до прикладу, Стівен Пеппер вводе поняття корінної метафори або базисної аналогії. Розглядається такий вид тропу під призмою « сфери фактів, які відкриті для сприйняття на рівні здорового глузду». Пеппер демонструє, що корінні метафори лежать в основі гіпотез про світобудову, які він класифікує на допустимі та недопустимі. Це свідчить про відкидання гіпотези анімізму на основі метафори «світ - це людина» за ії неточність і гіпотезу містицизму («світ - це дух» або «світ божественний») [10, с. 389].

Існує положення, згідно з яким «метафора виникає через глибинні особливості людського мислення, яка одночасно $\epsilon$ його знаряддям у пізнанні світу» [6, с. 252-276]. Метафора необхідна не лише для того, щоб, завдяки одержаному найменуванню, зробити думку зрозумілою для інших; вона необхідна для того, щоб об’єкт став доступний кожному.

Когнітивна теорія метафори функціонує в аспекті ознакової лексики на позначення ознак та процесів непредметного світу. Завдяки розвитку цієї теорії метафори, троп визначають не лише як порівняння двох застиглих семантичних форм, а як розумову структуру, в результаті взаємодії значень.
Кожен критик, поет чи письменник має власну позицію щодо походження та естетичної цінності метафори. Проте, в останнє десятиліття центр тяги у вивченні метафори змістився до різних галузей знань - логіки, психології, герменевтики та відгалужень лінгвістичної науки.

\section{Література:}

1. Апресян Ю. Д. Основания системной лексикографии // Апресян В. Ю., Апресян Ю. Д., Бабаева Е. Э. и др. Языковая картина мира и системная лексикография. - Москва, 2006. -216 с.

2. Балабан О. О. Метафора як семантична універсалія: автореф. дис. ... канд. філол. наук: спец. 10.02.15/ О. О. Балабан. - Донецьк: Донец. нац. Ун-т, 2006. - 20 с.

3. Никитин М. В. Курс лингвистической семантики // Никитин М. В. Курс лингвистической семантики. - СПб, 2006. - С. 67-153.

4. Ницше Ф. Об истине и лжи во вненравственном смысле. - Харвест, 2003. $-384 \mathrm{c}$

5. Флоря А. В. Російська стилістика // Флоря А. В., Русская стилистика. - Москва, 2013. - С. 311-356.

6. Deignan A. Metaphor // Metaphor and Corpus Linguistics. - John Benjamins Publishing Company, 2005. - $221 \mathrm{p}$.

7. Hintikka J. Metaphor // Aspects of Metaphor. - Kluwer, 2000. - $143 \mathrm{p}$

8. Kovecses Z. Metaphor // Metaphor: A Practical Introduction. Cambridge: Cambridge Univ. Press, 2010. - P. 67-276.

9. Ricoeur P. The Rule of Metaphor // Ricoeur P.The Rule of Metaphor: The Creation of Meaning in Language. - NY: Routledge Classics, 2004. P. $95-300$.

10. Stern J. Metaphor // Metaphor in Context. - The MIT Press, 2000. $-389 \mathrm{p}$.

11. Taverniers M., Ravelli L. Grammatical Metaphor // Views from systemic functional linguistics. - John Benjamins Publishing Company, 2003. - P. 402-445. 


\section{Кобильчук Вадим}

(м. Острог, Україна)

Національний університет «Острозька академія»

\section{КІНОФІЛЬМ ЯК ОКРЕМИЙ ВИД ДИСКУРСУ}

У дослідженні розглянуто лінгвістичні особливості дискурсу, та здійснено аналіз лексичних засобів, вживання дискурсу та їхніх особливостей ужитку у фільмі.

Ключові слова: дискурс, кіно-дискурс, фільм, кінотекст, аналіз.

В исследовании рассмотрены лингвистические особенности дискурса, и осуществлен анализ лексических средств, употребление дискурса и их особенностей употребления в фильме.

Ключевые слова: дискурс, кино-дискурс, фильм, кинотекст, анализ.

The study examined the linguistic features of discourse, and analyzed the lexical means, the use of discourse and their features of use in the film

Key words: discourse, film discourse, film, cine-text, analysis.

Мистецтво у будь-якому своєму прояві має важливе значення, оскільки організовує та систематизує почуття людини та має вплив на їі волю. Виникнення кінематографу змінило розвиток та значно доповнило не тільки культуру, але й суспільне життя: його здобутки масово входять в споживчий побут і трансформують світоглядну систему людини. Таким чином, кіно стало не лише чи не найбільш популярним та цікавим способом проведення дозвілля для людей будь-якого віку, але й потужним засобом впливу на свідомість людей, пропаганди та агітації. Саме кінодискурс $\epsilon$ ефективним засобом не лише одним 3 засобів передавання певної інформації до глядача, але й прихованого апелюван- ня до його почуттів та підсвідомості і, як результат, формування певних цінностей, поглядів та ідей, що досягається використанням різноманітних мовних засобів [2, с. 83].

Актуальність теми полягає в лексико-стилістичному дослідженні системи кінодискорсу, оскільки від якості та стилю залежить тлумачення головної ідеї кінофільму.

Метою $є$ аналіз та характеристика комунікативних особливостей втілення концептів в американському фільмі Бретта Ретнера «Червоний Дракон».

Завдання:

• уточнити у межах когнітивно-комунікативної парадигми методологію концептів;

- проаналізувати принципи дослідження концептів 3 точки зору їх структури та змісту, актуалізації в кінодискурсі.

Об'сктом дослідження $є$ кінофільм Бретта Ретнера «Червоний Дракон».

Кінодискурс є одним із найбільш актуальних об'єктів аналізу лінгвістичних наук сьогодні. Він здатен найбільше впливати на аудиторію та іï світогляд, нав'язувати та популяризувати певні моделі поведінки, ритуали тощо. Телебачення та кінематограф стали важливим чинником формування людської системи цінностей. Вважаємо, що саме голлівудське кіно сприяло популярності англійської мови у сучасному світі.

Кінодискурс - полікодова когнітивно-комунікатива структура, поєднана різними семіотичними одиницями в їхній нерозривній єдності яка характеризується зв'язністю, цілісністю, завершеністю [3, с. 71]. Кінодискурс відрізняється від усного дискурсу наявністю автора, оскільки художник не просто копіює дійсність, а осмислює їі в різній формі, створюючи екранний образ того чи іншого явища або індивідуума. Від письмового дискурсу кінодискурс відрізняється наявністю звукоряду. Дискурс кіно є динамічною системою звуко зорових образів або пластичних форм, яка існує в екранних умовах просторово-часових вимірів та аудіовізуальними засобами передає послідовність розвитку думки художника про світ і про себе. Поняття «дискурс» стає дуже популярним не тільки в лінгвістиці, а й у більшості гуманітарних 
наук. Пов'язано це було з так званим лінгвістичним поворотом, який в значній мірі був спровокований поширенням структуралістської методології і появою структурної лінгвістики.

Щодо структури дискурсу, то Е. В Костомарова виділяє як мінімум вісім компонентів інституційного дискурсу:

- соціальна місія;

- особлива мова, що виконує роль паролю ідентифікації;

- нормативна модель типової статусно-рольової комунікації;

- система базових цінностей;

- основні стратегії дискурсу;

- жанри інституційного дискурсу;

- прецедентні тексти;

- типові формули дискурсу (професіоналізми, кліше тощо) $[4$, c. 4$]$.

Місце кінодискурсу серед інших типів дискурсу визначається тим, які критерії взяті за основу. 3 позицій соціолінгвістики як критерії класифікації виступають типові учасники дискурсу, 3 позицій прагмалінгвістики - типи комунікативної тональності, 3 позицій лінгвосемантики - теми спілкування [3, с. 72]. Серед основних критеріїв виокремлення типів дискурсу розрізняють формальні, функціональні, змістовні критерії, пов’язані з категоріями дискурсу. Якщо відкинути в сторону систему звуко зорових образів, в нас залишиться кінотекст.

Саме в кінотексті кінознавці розділяють художній (ігровий) i документальний (неігровий) кінотекст. До документального кіно відносяться зйомки справжніх подій і осіб та наукове кіно (науково-популярне, навчальне, науково-дослідне, науково-виробниче). Художнім визнається кіно текст, в якому домінують іконічні знаки і стилізована розмовна мова, об'єднані естетичної функцією. В основному художній кіно текст використовує розмовний стиль, а також внутрішньо літературні мовні засоби (просторіччя, жаргони, діалекти); усна жива мова особливим чином відібрана і оброблена в ході створення сценарію. Діалогічна форма обміну, характерна для дискурсу кіно, сприяє протіканню мовної діяльності автоматично, поза обмірковування і відбору, це так звана мовна операція. Тим самим усний дискурс, представлений в ху- дожніх фільмах, достовірно відображає «живу мову» і служить релевантним джерелом для аналізу [2, с. 40]. Кінодискурс, шлях інтерпретатора у ньому пролягає від тексту до мови (у звичайній комунікації - від мови до тексту). Глядачі не можуть втручатися в кіно-дію. У межах кінодискурсу спостерігається складний «синтаксис» зображення і слова. Кінодискурс збагатив людську ментальність новим типом семіотичної одиниці, яка будується за законами невідповідності (монтажу). Кадри, розташовані поряд, вимагають знаходження зв'язку між ними, творчої уяви.

Поняття кінодискурс можна розглядати через поняття кінотексту, який є його частиною. Так, Ців'ян розглядає фільм як послідовність безперервних частинок тексту, а таку послідовність називає кінотекстом [3, с. 73].

В. С. Горшкова розглядає кінотекст як медіатекст, ставлячи його таким чином в один ряд із телетекстом, відеотекстом та копм'ютерним текстом. Всі медіа тексти виокремлюють в єдину групу за способом їх сприйняття (аудіовізуальним) та подання (екранний). Дослідник зауважує, що такий вид тексту виник із появою та розвитком засобів масової комунікації та не може існувати без них [1, с. 21].

1. Компонент «Інформація про фільм» має саме чітке мовне втілення. Це смислова модель, яка містить відповідь на питання «що? де? коли? » Вказується ім'я режисера і назву фільму (« що? »), місце (« де? ») і дата виходу в прокат (« коли? »). Вказівка тривалості фільму факультативно.

2. Компонент «Визначення місця кінофільму в світі кіно або в творчості режисера» займає важливе місце в композиції. Але в будь-якій позиції його значення велике: він визначає кут зору глядача [2, с. 75].

3. Компонент «Аналіз змісту і форми кінофільму» не передбачає обов' язкового аналізу всіх елементів змісту і форми. Як показало проведене дослідження В. С . Горшкової, як правило, в центрі уваги кінокритика стоять:

- Визначення режисерського задуму і режисерського відношення до сюжету; тематика і проблематика кінофільму, ідейний зміст кінофільму, система образів, особливості сюжету і компо- 
зиція кінофільму, роль пейзажів, мовна характеристика героїв, особливості стилю.

Отож, можемо сказати, що кінодискурс - це широке багаторівневе поняття, яке включає в себе не лише кінотекст та кінофільм, але й зміст, закладений авторами та його розуміння, сприйняття та інтерпретацію реципієнтом. Це сукупність вербальних та невербальних компонентів твору, а також всіх факторів, що впливають на його створення і які утворюють єдине смислове ціле.

\section{Література:}

1. Горшкова В. Е. Теоретические основы : дис. докт. фил. наук : 10.02.05 / Горшкова Вера Евгеньева - Иркутск, 2006. - 367 с.

2. Лютман Ю. М. Структура художественного текста / Лотман Ю. М. - Санкт-Петербург: Искусство, 1998. - 285 с.

3. Зарецька А Н. Особливості реалізації підтексту в кінодискурсі / Зарецька А. // Особливості реалізації підтексту в кінодискурсі : сб. ст. - Харків, 1996. - С. 70-74.

4. Костомарова Е. В. О различиях в понимании термина «дискурс» [Электронный ресурс] / Е. В. Костомарова. - Научно-практические конференции ученых и студентов с дистанционным участием. - Peжим доступа: [http://sibac.info/index.php/2009-07-01-10-21-16/508$\underline{\operatorname{lr}}]$.

\section{Козловська Ольга}

(м. Острог, Украӥна)

Національний університет «Острозька академія»

\section{ЕТИКЕТ У ВІРТУАЛЬНІЙ АНГЛОМОВНІЙ КОМУНІКАЦІЇ}

У тезах розглядається етикет у віртуальній англомовній комунікації. Зазначаються вербальні і невербальні компоненти нетикету, етикетні жанри, фактори комунікативних помилок, несвідоме та иілеспрямоване порушення нетикету, способи виправлення комунікативних помилок $i$ запобігання конфлікту

Ключові слова: етикет, комунікація, вербальні і невербальні компоненти, нетикет.

В тезисах рассматривается этикет в виртуальной англоязычной коммуникации. Указываются вербальные и невербальные компоненты нетикета, этикетные жанры, факторы коммуникативных ошибок, бессознательное и иеленаправленное нарушение нетикета, способы исправления коммуникативных ошибок и предотвращения конфликта

Ключевые слова: этикет, коммуникация, вербальные и невербальные компоненты, нетикет.

This research discusses etiquette in virtual English communication. Verbal and non-verbal components of netiquette, etiquette genres, factors of communicative mistakes, unconscious and purposeful violation of netiquette, ways to correct communication errors and prevent conflict are noted.

Key words: etiquette, communication, verbal and nonverbal components, netiquette.

В сучасному суспільстві простежується активний розвиток глобальної мережі Інтернет. Іїі можна трактувати як потужний засіб комунікації, що розширює та збільшує комунікативні можли- 
вості людини. Дослідники запевняють, що в середньому людина витрачає на спілкування близько $75 \%$ свого часу.

Мережа Інтернет в наш час представляє найрізноманітніші форм мережевого спілкування. Електронна комунікація у наші дні - це електронна пошта, форуми, чати, електронні 3МI, соціальні мережі он-лайн тощо. Віртуальна комунікація розглядається й досліджується у багатьох сферах - психології, літературознавстві, соціології, конфлітології.

Сьогодні підвищений інтерес до питань етикету можна пояснити переосмисленням самого поняття «етикет», як найважливішого твірного чинника існування людини в суспільстві. Етикет складова суспільної культури, або сукупність правил поведінки, що стосуються зовнішнього прояву суспільних відносин. Власне слово «етикет» (фр. etiquette - суворо встановлений порядок i форми поводження при дворах монархів) увійшло в міжнародний лексикон на початку XVII ст., за часів правління французького короля Людовіка XIV, коли спосіб життя та стилю французького двору поширилися як зразок для наслідування в усіх європейських державах [2].

Мовний етикет - це специфічні національні норми і правила мовної поведінки, що застосовуються під час входження співрозмовників у контакт. «Мова, - писав Олесь Гончар, - це всі глибинні пласти духовного життя народу, його історична пам'ять, найцінніше надбання століть, мова - це ще й музика, мелодика, барви буття, сучасна художня, інтелектуальна і мислитель на діяльність народу». Людина створила культуру, а культура - людину. Людина реалізується в культурі думки, культурі праці й культурі мови [5].

Якщо етикет - це правила поведінки в суспільстві, у відповідності з соціальними вимогами, то мовний етикет можна визначити як правила, які регулюють правила мовленнєвої поведінки. Етикет мовного спілкування, як і етикет загалом, регулює міжособистісні стосунки людей різного соціального статусу. Мовний етикет є системою, елементи якої, як правило, можуть бути реалізовані на різних рівнях мови.

Інтернет повністю змінив спосіб нашого спілкування. Вченими було підраховано, що 90\% веб-користувачів, підключені до мережі Інтернет, насамперед для перегляду та відправлення Iнтернет повідомлень. Не зважаючи на те, що для передачі екстралінгвістичних компонентів у веб-просторі розроблена спеціальна система емотиконів, які постійно розширюються за рахунок нових комбінацій текстових розділових знаків, Інтернет-повідомлення мають обмежену спроможність емоційного прояву, оскільки більшість повідомлень пишуться швидко й в стислій формі [1]. Емотикони (іконки емоцій) - це спосіб вираження людських емоцій за допомогою стандартних знаків пунктуації.

Інтернет повідомлення, як і спілкування в реальному житті підрозділяються:

- за наявністю суб’єктів: міжособистісні, індивідуально-групові, публічні;

- за ступенем підготовленості: спонтанні, підготовлені, частково підготовлені;

- за засобами й результатами комунікації: ефективні, неефективні;

- за умовами взаємодії: опосередковані, безпосередні [7].

3 розвитком та популяризацією комп'ютерної техніки та Iнтернету, з'являються та розвиваються характерні риси й особливості спілкування в комп'ютерному середовищі. Таким чином, англійська мова що перебуває в широкому вжитку у віртуальній мережі, може розглядатись як новий вид англійської мови, адже крім загальних рис, він також представляє деякі відмінні риси в словотворенні й лексиці. Знаючи правила та характеристики «мережевої англійської мови», люди мають змогу не тільки збільшити свій словниковий запас, а й ефективніше використовувати ресурси Інтернету та досягти найвищого рівня комунікації в віртуальному просторі. В наші дні, інформаційно-активне суспільство швидко розвивається і довгі форми слів неминуче змінюються стислими й лаконічними. Таким чином, абревіація $\epsilon$ найбільш часто вживаним методом теперішньої мережевої англійської мови.

Наприклад, уже класичною стала абревіатура ASAP (as soon as possible - зі значенням «якомога швидше»), що з'явилася саме в Інтернеті й швидко набула вжитку в усному мовленні та нео- 
фіційному письмі. Поширення також знайшла абревіатура LOL (laughing out loud - можна перекласти як «гучно сміюся»). Самих абревіатур на позначення ідіом і стійких сполук дослідники називають кілька десятків, з яких найхарактерніші: BTW (by the way), OTOH (on the other hand), FYI (for your information), AFAIK (as far as I know), ICBW (I could be wrong), GTSY (glad to see you), G2G (got to go), GMTA (great minds think alike), ICWYM (I see what you mean), KOC (kiss on cheek), ILU (I love you), ROFL (rolling on floor laughing), BF/GF (boyfriend/girlfriend), GTH (go to hell) [3].

У віртуальній англомовній комунікації часто простежується явище комбінації літер та цифр, що формують особливий тип абревіатури. Тобто, цифри часто використовуються, щоб замінити одну або декілька букв у слові, в тому випадку, якщо цифра співзвучна з частиною слова котру заміняють. Наприклад: r (are); b (be/bee); c (see); o (oh); oic (oh I see); icq (I seek you); how r u (how are you); b4 (before); 2B (to be); some 1 (someone); f2f (face to face); B2B (business to business); 3W (World Wide Web); 4ever (for ever).

Етикет - означає манеру поведінки, тобто норми й правила, які відображають уявлення про гідну поведінку людей у суспільстві. Це поведінка, що вимагає гарного виховання та дотримування законів. Існує також нетикет. У цілому положення нетикету можна розділити на три категорії:

- психологічні, емоційні (звертання: «Ти», «Ви», використання смайликів і їх кількість, підтримка новачків чи їх ігнорування тощо);

- технічні (використання рядків певної довжини, обмеження на розмір листів, їх підписи, допустимість написання у верхньому регістрі, допустимість форматування, виділення курсивом, кольором тощо);

- адміністративні (правила назв [заголовків] тем, правила цитування, допустимість реклами, допустимість флейму, необхідність додержуватися тематики співтовариства) [3].

Етикет також необхідний, коли мова йдеться про використання Інтернету. Це те, що зветься «нетикет», або «мережевий етикет». Нетикет являє собою філософію ефективного Інтернет зв'язку, який використовує загальноприйняті норми, як чинники для створення певних правил та стандартів комунікації в віртуальному просторі. Це також соціальний та моральний кодекс Інтернету, заснований на людяності.

Для уникнення помилок у мережі Інтернет необхідно знати загальні поняття:

- флейм - процес, що іноді виникає в Інтернеті, «словесна війна»;

- флуд - повідомлення у форумах і чатах, що мають великий обсяг і не несуть корисної інформації;

- спам - повідомлення, що надсилають невідомі Вам люди, без Вашої на те згоди;

- офтопік - повідомлення не за темою поточного обговорення чи поштової розсилки [4].

Отже, правила етикету в мережі Інтернет передбачають подвійну мету: допомогти новачкам й простим користувачам мінімізувати свої помилки, допомогти досвідченим мандрівникам кіберпростору покращити ефективність праці в мережі Інтернет. Більшість користувачі Інтернету воліли б заводити друзів, а не ворогів, тож якщо слідуватимуть декільком основним правилам нетикету, то матитуть менше шансів на припущення помилок, що заважають ефективному й приємному спілкуванню.

\section{Лiтература:}

1. Архелюк В. В. Особливості комунікації в мережі Інтернет // Мовні і концептуальні картини світу // Збірник наукових праць. Київ: Логос, 2002. - 590 с.

2. Гершуненко О. П. Знайомимось 3 Інтернетом: Навч. посіб. Львів: Світ, 2002. - 168 с.

3. Землянова Л. М. Современная американская коммуникативистика. - Москва: МГУ, 1995. - 271 с.

4. Столярова М. О. Етикет у віртуальній англомовній комунікації // Мовні і концептуальні картини світу // Збірник наукових праць. Київ: Логос, 2002. - 590 с.

5. Chis O.J. Electronic communication. - Oxford, 1995. - 214 p.

6. Netiquette and Strategies for Efficient Use. - New York. 1997. $114 \mathrm{p}$.

7. Robert L.S. Electronic communication. - Oxford, 1991. - 324 p. 


\section{Крайчинська Галина}

(м. Острог, Україна)

Наџіональний університет Острозька академія

\section{РОЗВИТОК КОМУНІКАТИВНИХ}

НАВИЧОК СТУДЕНТІВ НЕМОВНИХ СПЕЦІАЛЬНОСТЕЙ

(на основі професійно спрямованих комплексів 3 англійської мови видавництв Cambridge, Longman, Oxford University press)

У тезах розглянуто комунікативний підхід до вивчення професійної англійської у вищіий школі на основі англомовних комплексів видавництв Cambridge, Longman, Oxford University Press

Ключові слова: комунікативні навички, студенти немовних спеціальностей, комплекси з англійської мови, видавниитвво Cambridge, видавництво Longman, видавництво Oxford University Press

В тезисах рассмотрен коммуникативный подход изучения профессионального английского в высшей школе на основе комплектов издательств Cambridge, Longman, Oxford University Press

Ключевые слова: коммуникативный навыки, студенты неязыковых специальностей, комплекты издательства Cambridge, издательства Longman, издательства Oxford University Press.

The research analyzes the communicative approach to the learning of professional English in higher education based on the Cambridge, Longman, Oxford University Press course books

Key words: communication skills, students of non-linguistic specialties, Cambridge course books, Longman course books, Oxford University Press course books.

Комунікативні навички - це здатність людини взаємодіяти 3 іншими людьми, це навички ефективного спілкування, адекват- ного інтерпретування отриманої інформації. Ці навички є надзвичайно важливими, тому що необхідно взаємодіяти з багатьма людьми, мати здатність встановлювати контакт, підтримувати розмову і т. д.

НаУОА навчання професійної англійської на немовних спеціальностях спрямоване на професійно орієнтовані комунікативні навички студентів усіх кваліфікаційних рівнів, що відповідає сучасним нормативним матеріалам Міністерства освіти України, концепції Болонського процесу та Стратегії https://newdstat.ru/ gms/?state=4 розвитку «Україна - 2020 і Національній програмі вивчення та популяризації іноземних мов «Go Global» (2015).

Головна мета навчання професійної англійської на немовних спеціальностях полягає у формуванні комунікативних навичок, базою яких є професійно спрямовані сучасні навчально-методичні комплекси 3 англійської мови видавництва Cambridge та Longman рівнів Intermediate, Upper Intermediate, Advanced. Ці комплекси складаються 3 двох робочих книг (Student's book, Workbook), оснащені аудіозаписами (CD) та DVD-ресурсом. Книги для викладача (Teacher's book) містить детально розроблені методичні рекомендації. Комплекси є зручними у користуваннні, дають можливість провести самооцінювання студентів. Матеріал комплексів включає соціально-культурні та соціолінгвістичні знання і вміння, які забезпечують адаптацію студентів в англомовному соціумі і сприяють процесу соціалізації в англомовному суспільстві.

Європейський підхід до навчання професійної англійської свідчить, що комунікативний підхід передбачає розвиток практичних навичок використання знань на практиці. Як зазначає дослідниця сучасних тенденцій у викладанні англійської мови Ю. О. Полікарпова: «За такого підходу англійська мова є засобом та знаряддям для вирішення практичних завдань» [3].

Основні правила комунікативного підходу: участь студента у занятті (відповідальності студента за його комунікативну підготовку); висловлювання своєї точки зору; відмінна відповідь включає власний коментар студента. Обов'язковим елементом комунікативного підходу є з'ясування індивідуальних комуніка- 
тивних навичок та пізнавальних потреб студентів й обговорення перспективи підвищення їхніх комунікативних навичок.

Комунікативний підхід до вивчення мовних явищ є ключовою ланкою для налаштування студентів на продуктивну роботу, що відповідає вимогам сучасності.

Розвиток комунікативних навичок студентів немовних спеціальностей диктується вимогами викладання професійної англійської. Однією з головних передумов ефективного розвитку комунікативних навичок студентів при вивченні професійної англійської є комп'ютеризація, що сприяє підвищенню якості навчання і відповідає нормативним документам Міністерства освіти України.

Розвиток комунікативних навичок студентів передбачає використання особливих форм роботи, методів та способів, а саме: фронтальна робота; навчальна рольова гра; вільна дискусія; індивідуально-колективна комунікація; комунікація в малих групах; комунікація в парах.

Розвиток комунікативних навичок висуває певні вимоги до структури практичного заняття і передбачає створення на занятті сприятливого мікроклімату, який забезпечить набуття студентами досвіду комунікативної англійської, що вимагає застосовування ряду прийомів, які підтримують творчий підхід, ініціативу студентів, самостійне критичне мислення і базуються на принципі багатосторонньої взаємодії.

Створення комунікативного мікроклімату у навчанні професійної англійської надає заняттю активного комунікативного характеру, у ході якого студенти отримують досвід ведення вільної комунікації. Важливим у створенні комунікативного мікроклімату є навчати студентів ставити запитання й відповідати на запитання. Важливим є також і те, щоб викладач чітко формулював власну точку зору, вмів організувати коректний діалог, дав можливість виступити кожному студенту, вмів зацікавити студентів власною точкою зору і розумінням проблеми.

Комунікативний підхід при навчанні професійної англійської передбачає, що кожен студент висловлює власну точку зору, в ролі аудиторії виступає група і всі студенти беруть участь у дис- кусії. Така форма організації навчальної комунікації на немовних спеціальностях є доречною, викладач розпочинає заняття, представляє у загальних рисах зміст курсу, знайомить студентів 3 вимогами і започатковує обговорення основних тем.

\section{Література:}

1. Крайчинська Г. В. Інноваційні підходи до вивчення професійної англійської для студентів немовних спеціальностей // English for Specific Purposes. - Острог: Національний університет «Острозька академія», 2014. - С. 76-81.

2. Крайчинська Г. В. Самостійна робота студентів при вивченні професійної англійської // English for Specific Purposes. - Острог: Національний університет «Острозька академія», 2013. - С. 28-34.

3. Полікарпова Ю. О. Сучасні тенденції у викладанні англійської мови в Україні [Електронний ресурс]. - Режим доступу: https://www. narodnaosvita.kiev.ua).

4. Стратегія сталого розвитку «Україна-2020» [Електронний ресурс]. - Режим доступу: http://zakon3.rada.gov.ua/laws/show/5/2015.

5. National Foreign Language Learning and Promotion Initiative [Електронний ресурс]. - 2015. - Режим доступу: http://osvitacv.com/ uploads/go_global.pdf. 
УДК 811.111:004.738.5

\section{Курілович Ольга}

(м. Острог, Украӥна)

Національний університет "Острозька академія»

\section{АНГЛІЙСЬКА МОВА ЯК ГОЛОВНИЙ ЧИННИК ВПЛИВУ НА СЛОВОТВІР СУЧАСНОЇ КИТАЙСЬКОЇ ІНТЕРНЕТ-ЛЕКСИКИ}

У тезах розкрито способи впливу англійської мови на словотворення лексики інформаційних технологій китайської мови. Подано класифікацію запозичень на прикладі китайської інтернет-лексики.

Ключові слова: інтернет-лексика китайської мови, словотвір, запозичення, фонетичний, семантика.

В тезисах раскрыто способы влияния английского языка на словообразования лексики информационных технологий китайского языка. Представлена классификация заимствований на примере китайской интернет-лексики.

Ключевые слова: интернет-лексика китайского языка, словообразование, заимствования, фонетический, семантика.

The research reveals the ways English language influences the Chinese information technologies lexicon's word-formation. The classification of loan words is respresented on the example of Chinese Internet vocabulary.

Keywords: Internet lexicon of the Chinese language, word formation, loan words, phonetic, semantics.

Розвиток інформаційних технологій став справжнім проривом сучасності. У ході глобалізації у різних країн світу виникає потреба спільно використовувати, розуміти та удосконалювати комп'ютерні прилади та технології, пов'язані із ними.

Так як загальновизнаною комп'ютерою мовою $є$ англійська, очевидним є те, що іншим мовам світу в тій чи іншій мірі довелось підлаштуватись під іiі універсальність. Китайська мова

\footnotetext{
(С) Курілович Ольга, 2018
}

не стала виключенням, тому в ній чітко прослідковуємо вплив англійської мови в ході творення сучасної ІТ-лексики та інтернет-лексики, зокрема. Інтернет-лексика - це нове джерело слів сучасної китайської мови, а також новий об'єкт для дослідження.

Основними шляхами поповнення Інтернет-лексики будь-якої мови є словотворення та іноземні запозичення. Інтернет-лексика різних країн, в тому числі і китайської мови, знаходиться під впливом англійської мови. Тому й не дивно, що в китайській інтернет-лексиці можна зустріти слова такі як «拷贝»(кхао бей) копіювати (від англ. сору), «博客» (бо кхе) - блог (від англ. blog), «在线》 (дзай сьєн) - онлайн (від англ. online). Вся наведена лексика була запозичена $з$ англійської мови.

Найпростішим методом запозичення в китайській інтернетлексиці можемо вважати фонетичні запозичення 3 англійської мови. Даний тип словотворення характеризується підбором до англійської найбільш влучного фонетично ієрогліфу, де його лексичне значення не береться до уваги. Можемо навести такі приклади запозичень: «兔爸» (тху ба) - панель інструментів (від англ. Toolbar), де «兔》 (тху) окремо означає «заєць», а «爸》 (ба) - «батько»; «比特» (бі тхе) - «біт», двійкова одиниця інформації (від англ. bit), де «比» (бі) - порівняльна частка китайської мови, a «特» (тхе) - особливий, спеціальний. Прикладами семантичних запозичень, тобто таких, де при словотворенні до уваги бралася семантика окремого ієрогліфу, будуть наступні слова: «网页》 (ван є) - веб-сторінка, (від англ. Internet page), де «网》 (ван) мережа Інтернет, сітка, а 《页》 $(\epsilon)$ - сторінка, 《草根网民》(цхао ген ван мін) - «інтернет-маса», користувачі, які не вболівають за соціальні зміни в інтернеті, такі як: захист прав тварин, навколишнього середовища і т.д., (від англ. grassroots netizens), де « 草根》 (цхао ген) - «простолюд», букв. «коріння трави», а «网民» (ван мін) - інтернет-користувачі. Поєднання значення ієрогліфу і англійської фонетики спостерігаємо у фонетико-семантичних запозиченнях: 《黑客》 (хей кхе) - хакер (від англ. hacker), де «黑» (хей) - чорний, темний, а «客» (кхе) - гість, людина.

Запозичення займають $24 \%$ в сучасному китайському словнику Інтернет-лексики «Сіньхуа». Решту словникового запасу 
китайської мови було створено внутрішніми словотворчими інструментами. Жень Сюелянь виділяє 5 способів словотворення в китайській мові: морфологічний, синтаксичний, стилістичний, фонетичний і синтетичний.

Із постійною потребою прискорення вимови слів, в китайському словотворі значне місце почав посідати такий спосіб словотворення як «складноскорочені слова», які виникають на базі слова, словосполучення чи більш складної одиниці мови за рахунок випадання деяких iї елементів. Наприклад слово «苹果» (пхін гуо) - яблуко, марка техніки Apple, (від англ. apple) було скорочене від повної версії «苹果手机》 (пхін гуо шоу ці) - телефон Apple, де 《苹果》 (пхін гуо) - яблуко, а «手机》 (шоу ці) - телефон; «笔记本》 (бі ці пен) - зошит, блокнот, (від англ. notebook) було скорочене від повної назви «笔记本电脑》 (біці пен дієн нао), де «笔记本》 (бі ці пен) - зошит, блокнот, $a$ «电脑》 (дієн нао) - комп'ютер.

Одним із найбільш «різких» видів китайського словотвору є запозичення англійських інтернет-абревіатур та написання їх в китайській мові латинськими літерами. Даними прикладами будуть слова: «ВВ» (би би), (від англ. baby) - немовля, «В4» (від англ. before) - раніше. Також зустрічаємо приклади використання англійських слів без будь-яких змін у формі: «我很fine, 星期7 到我家eat饭, $O K$ ?» (во хен файн, сін чі ці дао во дзя іт фань, ОК?), де 《我很fine » (во хен файн) - в мене все добре, 《星期7» (сін чі ці) - в неділю, «到我家 eat饭, $O K ? »($ дао во дзя іт фань, ок?) - приходь до мене в гості на обід, ОК?

Проаналізувавши сучасну китайську інтернет-лексику можемо зробити висновок, що після прийняття політики «відкритості» і виходу Китаю на міжнародну арену бізнесу та світових технологій, англійська мова почала займати позицію активного проникнення як у повсякденну китайську мову, так і в професійну комп'ютерну термінологію. Найбільший відсоток у сучасному китайському словотворенні займають фонетичні, семантичні та фонетико-семантичні запозичення з англійської мови. Однак, все частіше починають вживатися нові «нестандартні» методи словотворення, які можуть послугувати об'єктом майбутніх досліджень.

\section{Література:}

1. A Comparison of Word-formation between Chinese and English [Електронний ресурс] // The Asian EFL Journal. - 2013. - Режим доступу: http://asian-efl-journal.com/dec_03_wa.pdf.

2. Хаматова А. А. Словообразование современного китайского языка / Анна Александровна Хаматова. - Москва, 2003. - 222 с.

3. Словник Сіньхуа - Пекін, 2004. - 692 с. - (Комерційна преса). 
УДК $81: 82.09$

\section{Максимчук Ірина}

(м. Острог, Україна)

Національний університет «Острозька академія»

\section{МОВНІ ЗАСОБИ ВИРАЖЕННЯ КОНЦЕПТУ КОХАННЯ} В РОМАНІ ЕЛІЗАБЕТ ГІЛБЕРТ «ЇСТИ. МОЛИТИСЯ. КОХАТИ.»

У тезах проводиться аналіз лексико-стилістичних та семантичних засобів реалізації концепту в автобіографічному романі Е. Гілберт «Їсти. Молитися. Кохати.»

Ключові слова: лінгвокультурний кониепт, мовна комунікація, мовностилістичні засоби, мовленнєво-комунікаційна ситуачія, лексичні засоби.

В тезисах проводится анализ лексико-стилистических и семантических средств реализачии кониепта в автобиографическом романе Э. Гилберт «Есть. Молиться. Любить.»

Ключевые слова: лингвокультурний концепт, языковая коммуникачия, лингвостилистические средства, речевой-коммуникационная ситуация, лексические средства.

The article analyzes the lexical-stylistic and semantic means of realization of the concept in the autobiographical novel E. Gilbert «Eat. Pray. Love.»

Key words: linguocultural concept, language communication, linguistic methods, speech and communication situation, lexical means.

Мова - це той засіб, за допомогою якого культури виражають себе, свою сутність. Вона виражає духовно-емоційний досвід кожного народу. Феноменом, який вміщає зміст певного поняття та його культурний смисл $є$ концепт.

Концепт кохання є одним із найважливіших фрагментів мовної картини світу та внутрішнього світу особистості, зокрема. Ця емоційна універсалія має певні характеристики, закріплені у свідомості. Традиційною проблематикою мовознавства $\epsilon$

(с) Максимчук Ірина, 2018 взаємозв’ язок категорій «мова й культура» та «мова й мислення». Проте на даному етапі розвитку лінгвістики та перекладознавства поняття концепту є ще недостатньо вивчене явище, яке потребує подальшого дослідження. Отже, дана стаття присвячена особливостям вираження концепту кохання у екстралінгвальному контексті.

Різні аспекти феномену концепт вивчалися такими дослідниками як В. І. Карасик, В. В. Красних, Л. О. Чернейко, З. Д. Попова Н. Д. Арутюнова, А. Вежбицька, О. С. Кубрякова, Ю. С. Степанов, О. О. Селіванова, А. М. Приходько та ін. Однак концепт розглядався переважно в ракурсі лексико-стилістичних характеристик до кінця першої половини ХХ-го ст.

Концепт кохання є досить цікавим об'єктом саме лінгвістичного дослідження тому, що культура кохання в європейському лінгво-культурному ареалі $є$ передусім культурою вербальною, тісно пов'язаною із словесним вираженням у мовленні та літе ратурі. Когнітивні можливості мовлення становлять собою ще недостатньо вивчені. Зважаючи на це, вважаємо нашу тему актуальною.

Об'єктом дослідження є мовні засоби вираження концепту «кохання» у романі Елізабет Гілберт «Eat. Pray. Love.». Предметом дослідження $є$ лінгвокогнітивні та культурологічні особливості вербалізації вищезгаданого концепту. У дослідженні ставимо і вирішуємо такі завдання: 1) визначити поняття та основні сутнісні характеристики лінгвокультурного концепту; 2) проаналізувати мовні засоби вираження концепту кохання у романі Елізабет Гілберт «Eat. Pray. Love.».

Концепт - один $з$ найбільш популярних і найменш однозначних термінів сучасної лінгвістики. Він пов'язаний насамперед iз антропоцентричною парадигмою мовознавства і когнітивнопрагматичної методології і використовується поряд 3 такими ключовими поняттями, як «дискурс», «картина світу» і ін. Функцією концепту є репрезентація світоглядних, інтелектуальних $\mathrm{i}$ емоційних інтенцій особистості, відображених в цих важливих явищ у художніх текстах. 
Концепт є лінгвокультурним явище. В межах такого трактування трактуємо концепт як одиницю, яка об'єднує в єдине ціле елементи галузі культури, свідомості й мовознавства. Як стверджує М. Полюжин: «концепт - культурно детермінований виразник свідомості, зафіксований у мові» [9, с. 18].

Культура має надзвичайно великий вплив на колективне та індивідуальне бачення романтичного. Характерної рисою культури США є індивідуалізм. Саме зосередження на власних інтересах, особиста автономія та індивідуальна ініціатива і $є$ тими чинниками, що формують особистісні погляди. Бажання людини бути самодостатньою значно впливає на іiі взаємостосунки із оточенням. Так, в індивідуалістичних культурах любов на основі шлюбу сприймається як ідеал. Однак, мотивація людини бути незалежною може вступати в протиріччя з необхідністю будувати серйозні стосунки. Представники більш консервативних культур із стабільними ціннісними засадами мають схильність поєднувати концепт «кохання» із «щастям» та «шлюбом.» Натомість, у індивідуалістичних культурах люди часто не включають аспект одруження у концепт кохання.

В Сполучених Штатах переважає більш реалістичне, не ілюзорне сприйняття любові. Культурні відмінності виявляються і у досвіді прогресії стосунків, здатності розвиватись у довгостроковій перспективі.

Чимало про концепт кохання в американській культурі можна зрозуміти аналізуючи художні твори. У них нерідко любовна історія може не закінчитися доволі трагічно, не завжди характерне щасливе завершення. Проте, навіть тоді, коли щаслива пара змушена розлучитися, це ще не кінець всього. У більшості випадків це тільки початок. Яскраво такий розвиток подій продемонстровано у романі Е. Гілюерт «Їсти. Молитись. Кохати.».

У творі, який використали для нашого дослідження, можна прослідкувати лінгвістичні особливості мовлення жінок і чоловіків, а також складові елементи концепту кохання у свідомості обох статей. Загалом концепцією книги є особистісні пошуки жінки, яка вирушає у навколосвітню подорож на пошуки відповідей.
Домінантним концептом у романі Елізабет Гілберт «Їсти. Молитись. Кохати.» виступає кохання. Ми виділили такі основні ціннісні компоненти концепту: LOVE - ADORATION, LOVE SELF-ABANDONMENT, LOVE - SELF-DEVELOPMENT, LOVE - DISAPPOINTMENT, LOVE - GOD.

Компоненти концепту мають різний рівень вираження, але відіграють визначальну роль у становленні особистості персонажу. Усі ці аспекти мають певну закономірність в сенсі впливу на мовну особистість Ліз Гілберт.

На початковому етапі розвитку історії концепт кохання реалізується як ADORATION, тобто любов Ліз як суб'єкта цього почуття знаходить своє вираження в його обожнюванні та вознесінні об'єкта свого кохання - Джованні. Головна героїня уявляє юнака як насамперед духовне, піднесене, неймовірне творіння (exalted spirit, divine essence). Вона застосовує численні епітети, метафори та гіперболізацію у вираженні своїх почуттів обожнювання. Наприклад:

Tall, dark and handsome twenty-five-year-old, as it turned out, with those giant brown liquid-center Italian eyes that just unstitch me [10]. У даному прикладі підкреслюється фізична привабливість. Це те, що, очевидно, перше привертає увагу героїні. Крім того, метафора eyes that unstitch особливо яскраво передає стан Ліз, коли вона бачить свого коханого, вона контроль над собою і уже не може ні думати, ні говорити спокійно.

На наступному етапі концепт кохання знаменує самозречення героя заради кохання (SELF-ABANDONMENT). Героїня настільки розчиняється у своєму почутті, що забуває себе колишнього, починає творити нову особистість, жертвуючи усім. Врешті-решт вона відчуває себе зламаною і зовсім у безнадії, що можемо спостерігати у прикладі:

I am a professional American woman in my mid-thirties, who has just come through a failed marriage and a devastating, interminable divorce that ended in sickening heartbreak [10]. Усі $з$ перелічених епітетів мають негативне емоційне забарвлення, що дає змогу глибше передати емоційний стан героя, а читачу якомога глибше проникнутися ситуацією. 
Переживши невдалий досвід одруження, у характеристиці шлюбу Ліз переважають мовні засоби, що демонструють його лише 3 негативного боку. Тобто, шлюб не входить у ідеальний концепт кохання. Наприклад:

In daylight hours, I refused that thought, but at night it would consume me. What a catastrophe. How could I be such a criminal jerk as to proceed this deep into a marriage, only to leave it? ...I don't want to be married anymore [10]. Остання фраза повторюється кілька разів, що свідчить про відділення концепту справжнього кохання від концепту сприйняття шлюбу.

У процесі переосмислення, наступає етап розчарування в коханні, тобто концепт реалізується як DISAPPOINTMENT IN LOVE. Це призводить до переосмислення дійсності та розуміння реальної ситуації. Головна герой робить висновок: об'єкт їі кохання виявляється не тим, за кого вона його приймала до певного часу, а іiі любов - це тільки їі самовіддача, за яку взамін вона нічого не отримав, крім розчарування.

This was my moment to look for the kind of healing and peace [10]. Наступним кроком Ліз після пережитих потрясінь $є$ пошук відповідей, бажання змін, кохання спонукало їі до самовдосконалення. Отже, наступний етап - це етап, де кохання для героїні значить SELF-DEVELOPMENT.

Переломним момент у житті героїні стає усвідомлення ще одного аспекту любові, вона пізнає Бога. Наприклад: I had finally noticed that I seemed to have reached a state of hopeless and lifethreatening despair, and it occurred to me that sometimes people in this state will approach God for help [10]. Ліз описує свій стан як безнадійний та безвихідний. Саме в такий складний час вона усвідомлює свою безсилість і звертається до вищих сил.

Хоча раніше, як вказує героїня, вона взагалі не цікавилась духовним, і радше сприймала це як скупчення різних недоведених теорій, яким важко довіряти, що чітко продемонстровано у наступному реченні: In the middle of that dark November crisis, though, I was not interested in formulating my views on theology. Of course, I've had a lot of time to formulate my opinions about divinity since that night on the bathroom floor when I spoke to God directly for the first time [10].

Отже, через динаміку ціннісних характеристик концепту кохання відбувається еволюція головної героїні. Формування мовної особистості проходить через різні стадії обожнювання, самозабуття, саморозвитку та врешті розчарування. Концепт кохання змінює свою цінність з позитивної на негативну, що позначається на свідомості особистості героїні.

Концепт кохання в романі Елізабет Гілберт характеризується доволі розмаїтим лексичним забарвленням. Проаналізувавши текст роману, ми виокремили чотири найбільші групи лексики за тематичною ознакою: лексика, на позначення негативних аспектів кохання; лексика, що позитивно характеризує кохання; лексика, яка характеризує одруження; лексика, що описує якості об'єкта кохання. Оцінна лексика надає негативності сприйняття, а в колоративній лексиці переважають темні тони, чорний колір.

У проаналізованому творі знаходимо метафори що за спрямуванням відносяться до позитивних понять. Ми виокремили такі основні метафори:

- LOVE IS A PHYSICAL FORCE

- LOVE IS FIRE

- LOVE IS A SUBSTANCE IN A LOCATION/CONTAINER

- LOVE IS A PLANT

- LOVE IS A JOURNEY

- LOVE IS A GAME

- LOVE IS WAR

- LOVE IS A DISEASE.

Авторка застосовує стилістичні фігури як засіб підсилення емоційної впливовості художнього тексту, що передбачає застосування різних синтаксичних конструкцій.

У деяких реченнях спостерігаємо комбіноване використання стилістичних засобів. Для підсилення негативних емоцій, суму та туги за коханим, автор застосовує окличні речення. Серед наявних прикладів стилістичних засобів домінують: концептуальні метафори, парцеляція, епосіопезис, риторичні запитання, анафору. Вони відображають елементи концепту кохання. Особливо 
чітко прослідкувати цілісність концепту можна за допомогою метафор. Одна $з$ причин, чому метафори здатні впливати на пізнання, те що такі поняття мають глибоке коріння в різних культурах, зокрема і західній. Метафора розкриває нюанси бачення кохання та його складнощів.

Мова художньої літератури функціонує як засіб творення естетичної реальності, вона виявляє творчі можливості та особливості кожного автора. Художній дискурс Е. Гілберт аргументовано висвітлює засади сприйняття концепту кохання. Головна героїня типова американського з різними перипетіями у особистому житті. Вона представниця середнього класу, що вірить у «американську мрію», і робить такі засади ціллю свого життя. Звичайно ж матеріальний статус не є запорукою щастя, тому Ліз стикається із значними проблемами у подружньому житті та переосмислює ціннісні характеристики кохання та стосунків.

Гілберт дійсно майстерний автор. Ї̈і художнє мовлення насичене різноманітними стилістичними фігурами, лексикою. Однією 3 характерних рис також є їі використання порівнянь та персоніфікацій. Серед важливих ознак концепту кохання ми визначили: акціональність, довготривалість, невловимість, позитивний статус закоханого, неконтрольованість, невмотивованість почуття, невзаємопов'язаність кохання та шлюбу, наявність перешкод у коханні.

Концепту кохання у сучасній англійській мові існує у свідомості носіїв англійської мови як складне ментальне утворення, яке конденсує різнопланові уявлення про почуття кохання. Концепт кохання як комплекс інтуїтивних та усвідомлюваних знань про почуття є фактором, що регулює вербальну та невербальну поведінку мовців у ситуаціях спілкування між закоханими.

\section{Література:}

1. Арнольд И. В. Стилистика современного английского языка. / И. В. Арнольд. - Москва: Просвещение, 1990. - 310 с.

2. Аскольдов С. А. Концепт и слово / С. А. Аскольдов // Русская словесность. От теории словесности к структуре текста. Антология / под ред. В. Нерознака. - Москва : Academia, 1997. - 279 с.
3. Галимова З. Ф. Сопоставление стратегий конструирования «положительного образа» (на матери але ток-шоу). / З. Ф. Галимова. Ижевск: Удмурток, 2008. - 118 с.

4. Калашник В. С. Образно-смислова єдність як засіб і знак у поетичній мовній картині світу // Вісник Харківського національного університету. Серія: Філологія. - 2001. - № 519. - Вип. 32. - 90 с.

5. Карасик В. И. О типах дискурса // Языковая личность: институциональный и персональный дискурс: Сб. науч. тр. Волгоград: Перемена, 2000. С. 5-20.

6. Кубрякова Е. С. Краткий словарь когнитивных терминов / Елена Самойловна Кубрякова, Валерий Закиевич Демьянков. - Москва. $-1996 .-245$ c.

7. Маслова В. А. Лингвокультурология: Учеб. пособие для студ. высш. учеб. заведений / В. А. Маслова. - Москва: Академия, 2001. $208 \mathrm{c}$.

8. Огаркова Г. А. «Кохання» як науковий емоційний концепт // Мовні і концептуальні картини світу. - Випуск 11. - Книга 2. - Київ: ВПЦ Київський університет. - 2004. - С. 22-35.

9. Полюжин М. М. Про синкретичні теорії концепту / М. М. Полюжин // Проблеми романо-германської філології: зб. наук. праць. Ужгород: ЛІРА, 2006. - С. 5-22.

10. Elithabet Gilbert. Eat. Pray. Love [Електронний ресурс]. - 2012. - Режим доступу до ресурсу: https://archive.org/stream/EatPrayLove/ Eat-Pray-Love_djvu.txt 
УДК 81'276.3:004.73

\section{Мельник Анна}

(м. Острог, Украӥна)

Національний університет "Острозька академія»

\section{ЛЕКСИЧНА ХАРАКТЕРИСТИКА МОЛОДІЖНОГО СЛЕНГУ НА ПРИКЛАДІ ПОВІДОМЛЕНЬ ҒАСЕВООК}

У тезах розглядається лексична характеристика молодіжного сленгу на прикладі особистих повідомлень Facebook. Саме глобальна мережа Інтернет є місием утворення більшої частини нових сленгових одиниць, які вживаються на віть у повсякденному житті, що $і$ є причиною важливості вміння їх функиіонально використовувати.

Ключові слова: патент, семантичне значення, сленг, Facebook.

В тезисах рассматривается лексическая характеристика сленга на основе приватных сообщений в глобальной сети Facebook. Глобальная сеть интернет есть местом создания большей части новых сленговых единиц, которые употребляються в повседневной жизни. Поэтому это важно уметь функиионально их употреблять.

Ключевые слова:патент, семантическое значение, сленг, Facebook.

The research deals with the lexical characteristic of youth slang based on personal messenges on Facebook. Global network Internet is a foundation to creation of a great number of slang items that are used on a daily basis. That is why, we should get to know how to use them functionally.

Key words: patent, semantic meaning, slang, Facebook.

У березні 2016 року соціальна мережа Facebook отримала патент на програмне забезпечення, здатне створити словник сленгу на основі лексики, яка використовується у просторах даної соціальної платформи. Під час сканування коментарів, особистих повідомлень та записів, дана програма шукатиме слова, словосполучення та цікаві короткі вирази, які матимуть незвичне семантичне значення. Тобто, соціальна мережа Facebook складе архів сленгових одиниць до того, як він стане відомим або ж «мейнстрімом». Контент, завантажений користувачами проходитиме через свого роду фільтр, який виділить слова, характерні для певних соціальних груп. Facebook детальніше розглянув інтернет-неологізми і склав список для зручнішого користування людей, які малознайомі з новою молодіжною лексикою.

Кожного року сотні нових слів, що додаються до словника, $є$ одиницею Інтернет сленгу. Деякі з них є абревіатурами (FOMO - Fear of Missinf Out), Yolo (You Only Live Once). Інші слова перейшли з однієї частини мови в іншу. Як приклад можна навести всім відомий іменник «Trend», що під впливом Інтернет сленгу зараз вживається частіше, як прикметник «It’s a trending worldwide». Багато слів, які вживаються лише про просторах Інтернету і у мовних ситуаціях, які його стосуються. Наприклад, «crowdfunding», «selfie», «cyberbullying'.

Сьогодні молодіжний сленг відіграє вагому роль у комунікації серед молоді. Мабуть, не знайдеться жодної молодої людини, яка не використовує сленг у повсякденному мовленні. Більшу частину сленгової молодіжної лексики утворюють саме неологізми, які утворюються та еволюціонують разом з різними змінами у самому соціумі. Молодіжний сленг - це щось середнє між інтержаргоном та мовною практикою народу і $є$ розмовно-побутовою мовою широких верств населення.

У сучасному світі саме соціальні мережі стали джерелом утворення сленгу, який закарбовується у нашій мові. Молодь вже більше і більше використовує терміни, які не зрозумілі більшій частині людей, яким за тридцять.

Також соціальна платформа Facebook визначає, які ж сленгові одиниці є найбільш використовуваними i, які необхідно знати, щоб уникнути непорозумінь під час листування. ASAP - As Soon As Possible, ASL - Age Sex Location, AKA - As Known As, 831 - I Love You, CTN - Can’t Talk Now, TTYL - Talk To You Later, KISS - Keep It Simple Stupid, FYI - For Your Information, TC - 
Take Care, PROPS - Proper Respeck and Acknoledgement, LMHO - Laughing My Heart Out, GR8 - Great, DIY - Do It Yourself, HMU - Hit Me Up, JK - Just Kidding, LOL - Laugh Out Loud, BBS - Be Back Soon, DIKU - Do I Know You, GF - Girlfriend, GN - Good night, GM - Good Morning, BF - Boyfriend, SUP - What Is Up, IDK - I Don't Know, BFF - Best Friends Forever.

Без знання значень цих термінів між людьми під час спілкування виникає непорозуміння, навіть якщо листувальники спілкуються однією і тією ж мовою. Кожного дня виникає все більше і більше нових утворень, які не стандартизуються та не входять у літературну мову та не числяться у словниках. Для зручності соціальна платформа Facebook (FB) створює списки найбільш використовуваних сленгових одиниць, або ж нових утворень, які набувають популярності. Новоутворення називаються «New On The Market»: CBH - Child Bearing Hips, SM - Social Media, ASN - Any Second Now, GRAND - One thousand (dollars), CHEERIO Good Bye, Sugar Daddy - Rich Old Man, YL - Young Lady, DINK - Dual Income No Kids.

Прослідковується явище зміни значення деяких сленгових одиниць з розвитком досліджуваної соціальної мережі. У минулому деякі вирази мали відмінне від сьогоднішнього значення. Наприклад, всесвітньовідома абревіатура IDK - I Don't Know у минулому означала «Ident-A-Kid», що було наймасштабнішою програмою розпізнання дітей.

Вищезгадані вирази широко вживані молоддю від 18 до 25 років, у старших людей можуть виникнути проблеми з інтерпретацією сленгових одиниць, що призводить до комічних ситуацій, які стають основою для створення анекдотів. Як ось наступна ситуація:

Mom, «Your great aunt just passed away. Lol».

Son, «Why is that funny?»

Mom, «It's not funny, David. What do you mean?»

Son, «Mom, lol means laughing out loud!»

Mom, «Oh my Godness!! I sent that to everyone. I though it meant lots of love. I have to call everyone back. Oh God».
Було виконано дослідження використання чисел у ролі сленгових одиниць та новоутворень. Від моменту утворення соціальних мереж користувачі шукали різні способи економії часу, тому часто використовували числа для позначення слів на основі співзвучності. Наприклад, 2 - to, too (2U - to you), 4 - for (4U for you), 10x - Thanks, $10 \mathrm{q}$ - Thank you, CUL8ER - See you later, 2 moro - tomorrow, in da shop - in the shop.

Також у Facebook ігноруються правила граматики, зокрема правопису, пунктуації, правопису великої літери та інше. Якщо ж людина хоче підкреслити чи наголосити щось, то усе своє повідомлення пише, використовуючи великі літери. Наприклад, «STOP IT»- вираз, що підкреслює роздратованість користувача. Правила пунктуації порушуються з тією ж ціллю. У кінці речення користувач може використати не одну крапку, а декілька, не один знак оклику, а три та більше. Це також вказуватиме на те, що на це повідомлення потрібно звернути особливу увагу. Також прослідковується тенденція пропуску апострофа у випадках присвійного відмінку. Наприклад: «John's book»-«Johns book».

Ономатопея також популярне явище у просторах досліджуваної соціальної платформи. Щоб зекономити свій час користувачі замість дієслова «laughter» можуть використати «hahahha»або ж іспанське «јајајајајаја».

Графічні скорочення слів використовуються не лише у інтернеті, а й у відомих газетах, журналах та статтях. Прикладів можна навести надзвичайно багато: advertisement - ad, examination exam, telephone - phone, website - site, photograph - photo, statistics - stats, hamburger - burger, graduate - grad, teenager - teen.

Префіксація, суфіксація, складання слів також відіграють роль у створенні інтернет-сленгу у Facebook. Було досліджено найвживаніші частки для створення нових мовних одиниць: up, down, spam, web, book, line, name, dot, net (offline, download, downshift, update, upgrade, netbook, notebook, wecam, webpage). Префікси суber-, de-, en-, giga-, hyper-, inter-, meta-, micro-, multi-, pre-, un-, techno- та найбільш вживані суфікси -ise/ize створюють сотні нових слів, які набирають популярності у соціальні мережі. Наприклад, deactivate, decode, delink, deregulate, deauthorise, delist 
hyper-: hyperactive, hyperlink, hypermedia, hyperspace, hyperactive -ise/ize:authorize, popularize, symbolize, computerize, socialize, automize, globalize - ware: emailware, bookware, software, SIMware, postcardware [2].

Спілкування визначається як активний, обмежений мовою, залежний від ситуації, цілеспрямований процес передачі та прийому інформації між співрозмовниками. Сленг не $є$ літературною мовою, тому слід бути обережним при його використанні. У різних мовленнєвих ситуаціях люди проявляють різну мовленнєву поведінку. Слід мати на увазі, що саме мовленнєва поведінка i вибір слів показує освіченість та культурність людини та ії інтелектуальні здібності. Це може проявлятися у доборі слів, тобто чи людина обирає слова відповідні за стилем, складність слів, інтонація, типи речень та способи їхньої побудови. Також важливим чинником $є$ міміка та жести, який показує мовленнєву поведінку людини. Тому вибір сленгових слів відповідно до стилю, свідчить про високий рівень розвитку та про дотримання моральних норм поведінки на публіці.

\section{Література:}

1. Гудманян А. Г. Проблема словотвору та перекладу українського та американського сленгу / А. Г. Гудманян, І. А. Гонта // Вісник Луганського національного університету. - № 13 (200). - 2010. - С. 129-136.

2. Єфімов Л. П. Стилістика англійської мови і дискурсивний аналіз: навчально-методичний посібник / Л. П. Єфімов, О. А. Ясінецька. - Вінниця : Нова книга, 2011. -240 с.
УДК 81 '38:791.43

\section{Мирончук Ірина}

(м. Острог, Україна)

Національний університет «Острозька академія»

\section{ОСОБЛИВОСТІ ВИКОРИСТАННЯ}

\section{СТИЛІСТИЧНИХ ЗАСОБІВ НА ПОЗНАЧЕННЯ ОБРАЗІВ ЗЛА} (на прикладі кінотрилогії «Володар кілець»)

У тезах розглянуто основні стилістичні засоби зображення образу зла, виявлені в кінотрилогії «Володар кілеиь». Розкривається значення та функиії стилістичних засобів у мовній системі кінотрилогії.

Ключові слова: кінодискурс, стилістичний засіб, порівняння, оксиморон, алюзія, анафора.

В тезисах рассмотрены основные стилистические средства изображения образа зла, обнаруженные в кинотрилогии «Властелин колеи». Раскрывается значение и функиии стилистических средств в языковой системе кинотрилогии.

Ключевые слова: кинодискурс, стилистическое средство, стравнения, оксюморон, аллюзия, анафора.

The research analyzes stylistic devices, which depict the image of evil in The Lord of the Rings. The meaning and functions of stylistic devices in the language system of the film are revealed.

Key words: film discourse, stylistic device, simile, oxymoron, allusion, anaphora.

Збільшення впливу кінематографу на світогляд людини призвело до зростання інтересу до вивчення явища кінодискурсу в сучасній лінгвістиці. Кіно $є$ частиною побуту людини, тому й має великий вплив на формування світосприйняття. За допомогою кінодискурсу можна вплинути на ставлення соціуму до різних речей. У фільмах зі стилістичної точки зору вживається найбільш неоднорідна лексика, яка спрямована на загальне розуміння, тому 
часто використовуються стилістично різноманітні лексичні одиниці. Саме тому, нам варто приділити значну увагу стилістичним засобам, які є найбільш вживаними в кінодискурсі.

Науковці все частіше цікавляться поняттям кінодискурсу, яке останнім часом завоювало чималу популярність. Нами було розглянуто праці таких науковців, як: Г. Почепцов, В. І. Карасик, А. Н. Зарецька, М. А. Сфремова. Сдиного та всеохоплюючого визначення кінодискурсу так і не було представлено. Недостатньо дослідженими $є$ і особливості вживання стилістичних засобів у кінодискурсі та їх роль у сприйманні кінофільму глядачем, чим і зумовлена актуальність нашої роботи.

Мета нашого дослідження полягає в аналізі стилістичних засобів зображення образів зла в кінотрилогії «Володар кілець». Реалізація мети передбачає виконання таких завдань: 1) виявити та описати основні стилістичні засоби, використані в кінотрилогії; 2) здійснити аналіз лексики на позначення зла в даному тексті; 3) на основі проведеного дослідження проаналізувати функціональні особливості вжитих стилістичних засобів. Об'єктом нашого дослідження є американська кінотрилогія «Володар кілець», англомовна версія.

3 метою створення яскравих образів та кращої передачі інформації в кінодискурсі використовують різноманітні засоби, які покращують сприйняття людьми того чи іншого фільму [2, с. 6] . Це зокрема стилістичні одиниці: порівняння, оксиморон, алюзія, анафора тощо. Саме ці засоби роблять кінодискурс легкодоступним та зрозумілим усім глядачам. Впродовж останнього століття кінодискурс став не лише способом розваги чи донесення інформації до глядача, а й засобом впливу та нав'язування певних цінностей, поглядів та ідей, що досягається вживанням певних мовних засобів.

Ми детальніше проаналізували всі вищезгадані лексичні одиниці на позначення образів зла на прикладі тексту кінотрилогії «Володар кілець». Цей кінофільм про боротьбу добрих та злих магічних сил, а тому наскрізь змережаний магічними поняттями та явищами. Саме тому у кінотрилогії важливими є художні засо- би мовлення, які створюють магічну атмосферу та підтримують інтригу.

Здійснюючи стилістичний аналіз лексики кінотрилогії П. Джексона «Володар кілець», виявили такі мовні засоби характеристики образів зла: метафори, оксиморони та афоризми.

Найбільшою групою стилістичних засобів, до яких вдається автор, є порівняння - це зіставлення одного предмета з іншим 3 метою більш яскравої й наочної характеристики одного 3 них [1, c. 49]. Розглянемо таке речення:

Where is the spring and the harvest and the tall corn growing? They have passed like rain on the mountain, like a wind in the meadow; The days have gone down in the West behind the hills into shadow [4]. Теоден цитує вищесказане, коли його люди готуються до битви в Хельмовій ущелині. Дні слави, миру й процвітання закінчилися й пройшли, так само як погода і сезони змінюються, коли тінь, зло, смерть та загибель підкрадається. Це порівняння є дуже ефективним, так як перехід від «Золотої доби» до нового часу є досить різким і похмурим.

Іншою категорією стилістичних маркерів на позначення зла, які ми виявили, є оксиморон, стилістична фігура, що полягає у зведенні слів або словосполучень, значення яких взаємовиключає одне одного, створюючи ефект смислового парадоксу. Наприклад:

I'm sure the Orcs have plenty more black-fire. I'm going to ask you to find and destroy it all [4]. Орки є втіленням зла, вони не можуть співіснувати з іншими істотами на Землі. В даному випадку злу сторону, а саме орків, варто знищити, оскільки їх сутність, свідомість повністю проникнуті злими намірами, на яких автор наголосив, використавши оксиморон black-fire.

Негативні персонажі та події кінофільму зображено й іншими стилістичними засобами, такими як: алюзія та анафора. Алюзія - це художньо-стилістичний прийом, що містить указівку, аналогію чи натяк на певний історичний, міфологічний, літературний, політичний або ж побутовий факт, закріплений у текстовій культурі або в розмовному мовленні [3, с. 60]. Прикладами використання алюзії відтворення зла в кінотрилогії «Володар кілець» є: 
But thirty silver pennies was a sore blow to him, and being cheated by Bill Ferny made it harder to bear [4]. Ця алюзія є відтворенням біблійного сюжету, а саме, зради: Іуда отримав 30 срібників за зраду Ісуса Христа. Таку ж кількість срібників було дано Білу, щоб він обманув хобітів.

Розглянемо ще одну стилістичну фігуру, яскраво представлену у кінотрилогії «Володар кілець». Мова йде про так звану анафору, що створюється повторенням одних і тих самих елементів мови на початку кожного паралельного ряду [3, с. 72]. Проілюструємо приклади використання лексичної анафори у фільмі. Наприклад:

One Ring to rule them all,

\section{One Ring to find them,}

One Ring to bring them all and in the darkness bind them [4]. Повторення слів «One Ring» означає могутність персня, або точніше його небезпеку. Один перстень, в якому величезна сила зла, здатен зруйнувати весь світ, повторення його підкреслює всю велич та важливість кільця.

Отже, проаналізувавши стилістичні одиниці, які відносимо до засобів зображення зла, можна зробити висновок, що саме вони становлять лексичну основу даного кінофільму. Саме ці засоби насичують барвами мовлення героїв, передають картину в повному обсязі й є невід’ємною частиною кінодискурсу. Найважливішою, на нашу думку, у запропонованій вище класифікації є лексичні одиниці на позначення зла. Це найчисленніша підгрупа мовних засобів, на яку ми звернули особливу увагу, адже весь сюжет, досліджуваного кінофільму, побудований на протистоянні добра й зла, життя та смерті. Вловлюючи смаки телеаудиторії, автори сценарію доклали зусиль, щоб задовольнити їх, навіть шляхом вживання лексики на позначення смерті. Варто зазначити, що було досягнуто високого рівня різноманітності, що свідчить як і про багатство англійської мови у цій сфері, так і про вміння сценаристів розуміти інтереси публіки.

\section{Література:}

1. Антрушина Г. Б. Лексикология английского языка / Антрушина Г. Б. Афанасьева О. В., Морозова Н. Н. - Москва: Изд. дом «Дрофа», 1999. - 198 с.

2. Грицай I. С. Мовні особливості сучасного кінодискурсу / I. С. Грицай. - Київ: Вища школа, 2012. - 42 с.

3. Коломієць 3. Г., Львова Н. Л., Микитюк І. М. Практикум зі стилістики англійської мови: навч. посібник / 3. Г. Коломієць, Н. Л. Львова, I. М. Микитюк. - Чернівці, 2010. - 96 с.

4. Lord of the Rings. - Режим доступу: http://www.lordoftherings.net/ 


\section{Місюк Ярослав}

(м. Острог, Україна)

Національний університет «Острозька академія»

\section{АНГЛЙССКА СЛЕНГОВА ЛЕКСИКА ТА НЕТИКЕТ} ЯК ЧИННИКИ ЕФЕКТИВНОЇ ВІРТУАЛЬНОЇ КОМУНІКАЦІЇ

У тезах розглядається англійська сленгова лексика у соиіальних мережах і ї̈ вплив на соиіум, а також перераховуються правила та положення нетикету.

Ключові слова: англійський сленг, нетикет, віртуальна комунікація, соиіальна мережа, Інтернет.

В тезисах рассматривается английский сленговое лексика в социальных сетях и ее влияние на сочиум, а также перечисляются правила и положения нетикета.

Ключевые слова: английский сленг,нетикет, виртуальная коммуникаџия, социальная сеть, Интернет.

The research deals with the English slang vocabulary in social networks and its influence on the society. Also, it lists the rules and regulations for netiquette.

Key words: English slang, netiquette, virtual communication, social network, Internet.

У тезах у загальному вигляді ставиться проблема вивчення англійської молодіжної лексики у мові сучасного Інтернету та правила її використання. У семантико-функціональному аспекті розглядаються сленгізми, які виникли на тлі медіа простору.

Об'єктом дослідження $є$ англомовний молодіжний сленг та нетикет. Предметом дослідження є особливості спілкування в соціальних мережах. Метою дослідження є здійснення аналізу лінгвістичних особливостей формальної та неформальної лексики та нетикету на прикладі соціальних мереж.

(C) Місюк Ярослав, 2018
Актуальність дослідження зумовлена швидко зростаючою глобалізацією та комп'ютеризацією, що тісно пов'язані між собою. Природнім є факт відображення процесів глобалізації та комп'ютеризації в лінгвістичному світі, особливо в побутовому та професійному середовищі тих людей, які причетні до них. Особливо яскраво це відображається на спілкуванні молодих людей, які все частіше користуються сленгом як у реальному, так і у віртуальному середовищі. Як результат, щоб активно володіти засобами комунікації сучасної молоді, нетикет та сленг потребує більш детального дослідження.

Теоретичною основою статті $\epsilon$ праці С. Бибик, В. Амінової, А. Д. Бєлової та інших. Особливе місце слід відвести праці Столярової М.О. де не лише найбільш повно та глибоко розкрито усі проблеми віртуальної комунікації, а й окреслено норми та правила використання молодіжного сленгу в Інтернет спілкуванні.

У ході роботи, використано такі методи дослідження:

- Аналіз - це метод, в ході якого предмет, що вивчається умовно або практично поділяється на окремі складові частини об'єкта, властивості, ознаки. В той самий час, кожен елемент досліджується як частина цілого.

- Синтез - об'єднує частини, що були розчленовані та дослідженні у процесі аналізу, для того, щоб встановити певний зв'язок між ними і відкрити предмет як єдине ціле.

- Метод суцільної вибірки - вибір певних одиниць для проведення дослідження.

3 розвитком та популяризацією комп’ютерної техніки та Інтернету, з'являються та розвиваються характерні риси й особливості спілкування в комп'ютерному середовищі. Інтернет, як популярний засіб масової комунікації, потребує простої та зручної мови, для того щоб люди мали змогу використовувати ії в спілкуванні, обираючи комунікацію в віртуальному просторі. Англійська мова, як найбільш поширена мова в Інтернеті, привертає увагу людей та науковців через свої характерні особливості.

Таким чином, англійська сленгова лексика, що перебуває в широкому вжитку у віртуальній мережі, може розглядатись як новий вид неформальної англійської мови, адже крім загальних 
рис, він також представляє деякі відмінні риси в словотворенні й лексиці. Отже, таку англійську ми можемо сміливо назвати сленгом. Знаючи правила та характеристики «мережевого сленгу», люди мають змогу не тільки збільшити свій словниковий запас, а й ефективніше використовувати ресурси Інтернету та досягти найвищого рівня комунікації в віртуальному просторі. Найбільшими носіями «мережевого сленгу»є молодь [2].

Ми вирішили навести приклади сленгу і провели дослідження. Нами було здійснено аналіз випадково вибраних історій, написаних у соціальних мережах, таких як: Facebook, Instagram, Twitter та ін. Було розглянуто 70 лексичних одиниць і згруповано їх на 5 груп: скорочення, звуконаслідування, асиміляція, акроніми і змішування.

Розглянемо першу групу лексичних одиниць утворених шляхом скорочення. Молодіжні висловлювання насичені сленговими одиницями, які утворені різними способами. Більшість 3 них побудовані методом абревіації - утворення нових слів шляхом скорочення існуючих. В сучасній англійській мові модно скорочувати все, що піддається скороченню [1]. Англійська мова, і без того відрізняється лаконічністю, досить впевнено і без жалю розправляється 3 довгими і не дуже довгими словами:

- graduate - grad

- technological - techno

- exhibition - exhibit

- exposition - expo

- doctor - doc

- fabulous - fab

- psychopath - psycho

- demonstration - demo

- criminal - crim

- parents - rents

- definitely - def

- homosexual - homo

До другої групи відносться лексичні одиниці утворені методом звуконаслідування. Найпопулярніший вираз - «hahahaha» для позначення сміху, зустрічаються також такі одиниці, як «zzZ» та «click», що відповідно означають сон та натискання клавіші. До цієї ж групи відносимо слова:

- Flick - Клац (клацання)

- Crash - Ламати (ся)

- Smack - цілувати

- Pow - Бух

Схожим способом до звуконаслідування є асиміляція. Наприклад, ми знайшли такі відомі всім вирази:

- wanna - want to

- gonna - going to

- gotta - got to

- dunno - I don't know

- wagwan - what's going on

Проте найпоширенішими в соціальних мережах є акроніми. Серед них:

- LOL - laughing out loud

- IDK - I don't know

- ASL - age, sex, location

- B4 - before

- BF - boyfriend

- CSA - cool sweet awesome

- CUL - see you later

- d00d - dude

- DIKU - do I know you

- GN - good night

- I <3 U - I love you

- IMHO - in my humble opinion

- PLZ - please

- 1daful - wonderful

- 2day - today

- 4ever - forever

- ABT2 - about to

- ASAP - as soon as possible

- aight - all right

- AML - all my love

- B4N - bye for now 
- BIBI - bye bye

- BON - believe it or not

- BW - best wishes

- BZ - busy

-c ya - see you

- c\% $\% 1-\mathrm{cool}$

- $\mathrm{CM}$ - call me

- dem - them

- DYLI - do you love it

- EZ - easy

- F2T - free to talk

Також нами було виявлено велику кількість змішування. Змішування - це утворення нових слів шляхом комбінування частин різних слів, або комбінування повноцінного слова 3 частиною іншого слова (наприклад $\operatorname{smog}=\operatorname{smoke}+$ fog). Загалом $є$ два типи змішування в мережевій англійській мові:

1. Змішування частин різних слів/ змішування цілого слова й частини іншого:

- informercial - information commercial

- autologon - automation logon

- infocosm - information cosmos

- computerate - computer literate

- commernet - commercial network

- netzine - netmagazine

- infochannel - informal channel

- technet- technology net

- Webster - web master

2. Комбінація повноцінного слова 3 першою літерою іншого слова:

-e-mail - electronic mail;

-e-cash - electronic cash;

- e-wallet - electronic wallet;

- e-life - electronic life;

- e-book - electronic book.

Всі ці лексичні одиниці потребують детального вивчення. Якщо не знаєте правильного значення слова, Ви легко можете образити людей, навіть якщо Ви не маєте наміру цього робити. Або ж Ви можете неправильно зрозуміти інших користувачів соціальних мереж і сприйняти їхні висловлювання як образу.

Саме ці проблеми та розширення сфер молодіжного спілкування за рахунок розвитку віртуальної комунікації спричинило вироблення особливих правил поведінки в Інтернеті, які називають новим словом Інтернет-етикет, або молодіжний нетикет (від англ. «net» мережа та «etiquette» етикет) [5].

Нетикет становить філософію ефективного Інтернет спілкування, який використовує загальноприйняті норми, як чинники для створення певних правил та стандартів комунікації в віртуальному просторі. Це також соціальний та моральний кодекс Iнтернету, заснований на людяності. Деякі люди ігнорують правила нетикету і не вважають за потрібне дотримуватись його норм. Проте, етикет особливо важливий і потрібний у використанні віртуальної мережі та є невід’ємною її частиною. Мережевий етикет, в першу чергу, потрібний для того щоб «вилікувати» Інтернет від масового вторгнення неадекватних користувачів.

У сучасній культурі, люди отримують більшу частину інформації опосередковано, а не через безпосередній досвід. Опосередковані джерела, в свою чергу, можуть деформувати людське розуміння реальності. Таким чином, Інтернет тепер став новим «інструментом», який розвивається та істотно впливає на повсякденне життя людей, стаючи більш популярним у використанні, особливо серед молоді.

Молодіжний сленг використовує три типи лексики:

- психологічні, емоційні (звертання: «Ти», «Ви», використання смайликів і їх кількість, підтримка новачків чи їх ігнорування тощо);

- mехнічні (використання рядків певної довжини, обмеження на розмір листів, їх підписи, допустимість написання у верхньому регістрі, допустимість форматування, виділення курсивом, кольором тощо);

- адміністративні (правила назв [заголовків] тем, правила цитування, допустимість реклами, допустимість флейму, необхідність додержуватися тематики співтовариства) [6]. 
Необхідно знати деякі загальновживані поняття:

- флейм - процес, що іноді виникає в Інтернеті, «словесна війна»;

- флуд- повідомлення у форумах і чатах, що мають великий обсяг і не несуть корисної інформації;

- спам - повідомлення, що надсилають невідомі Вам люди, без Вашої на те згоди;

- oфmoniк - повідомлення не за темою поточного обговорення чи поштової розсилки [8].

Коли молодь стає учасником нової культури, (а віртуальний простір має свою власну культуру), вона ризикує здійснити певні соціальні помилки. Більше того, під час комунікації у віртуальній мережі молоді люди часто забувають, що вони спілкуються з реальними людьми, не просто з віртуальними персонажами на моніторі, а зі справжніми, живими людьми. Таким чином, частково в результаті того що молодь, а головним чином нові користувачі, забуває про те, що користувачі в Інтернет все ще реальні люди, й частково не знаючи правил нетикету робить дуже багато помилок.

Основні правила нетикету:

1. Ставитись до інших так, як Ви хочете щоб ставились до Вас. Це правило старе, але досить корисне, й допоможе вам в різних ситуаціях як в мережі Інтернет, так і поза їі межами;

2. Уникати флеймінгу. Флеймінг - це форма словесної образи, коли Ви з якоїсь причини навмисно виявляєте неповагу до іншого користувача. Ви можете бути незгодні з чиєюсь думкою, але існує багато інших способів висловити іншу точку зору без навішування ярликів та агресивної поведінки. Постійні суперечки й образи навряд чи сприятимуть хорошим стосункам 3 іншими користувачами.

3. Поважайте авторське право. Інтернет містить в собі багато різноманітних та цікавих речей. Кожен користувач має можливість знайти будь-яку інформацію на будь-яку тему. Проте, ці речі мають авторські права та ліцензії. Копіювання інформації без дозволу автора, або видавання цієї інформації за свою власну не тільки зруйнує Вашу репутацію онлайн, але й може потягнути за собою високі штрафи.
4. Не друкуйте все великими літерами. Це відразу кидається в очі. Більше того, це змушує людей думати, що Ви кричите на них. Можна написати одне чи два слова великими літерами, щоб акцентувати на них увагу, але не варто робити це з усім текстом.

5. Не поширюйте спам, зокрема небажаний рекламний або комерційний вміст, а також небажані чи масові розсилки.

6. Будьте чесними. Не підроблюйте статистику сторінки чи сайту та не видавайте себе за іншу людину, адже це не лише зашкодить вашій репутації, але й викличе багато інших проблем в майбутньому.

7. Використовуйте належну граматику й орфографію. Зрозуміло, що так чи інакше, всі користувачі I нтернет мережі допускаються певних помилок у правописі чи граматиці, але якщо їх занадто багато - це починає дратувати. Використання браузера з вбудованою функцією перевірки орфографії може стати Вам у пригоді.

8. Дотримуйтесь загальних положень та умов використання. Більшість сайтів мають умови політики обслуговування, де також перераховані правила нетикету. Уважно читайте й дотримуйтесь цих правил.

Правила мережевого етикету мають подвійну мету: допомогти новачкам й простим користувачам мінімізувати свої помилки, та допомогти досвідченим мандрівникам кіберпростору покращити ефективність праці в мережі Інтернет. Більшість людей воліли б заводити друзів, а не ворогів, отож якщо слідувати декільком основним правилам етикету, Ви матимете менше шансів на припущення помилок, що заважатимуть ефективному й приємному спілкуванню.

Враховуючи вище сказане формулюємо визначення нетикету - це не просто зведення правил писемного спілкування в Інтернеті, але й система, що оріснтує користувачів Мережі на дотримання принципів англійської мовної культури незалежно від того, віртуальна вона чи реальна. Таким чином, можемо стверджувати, що при правильному використанні молодіжної сленгової лексики і враховуючи всі правила та норми нетикету спілкування буде цікавим і ефективним. 


\section{Література:}

1. Амінова В. Структурно-семантичні особливості молодіжного сленгу в англійській і французькій мовах // Л. В. Амінова. - Київ: Вид. дім»Башкирський державний університет». - Уфа, 2004. -18 с.

2. Архелюк В. В. Особливості комунікації в мережі Інтернет // Мовні і концептуальні картини світу // Збірник наукових праць. Київ: Логос, 2002. - 590 с.

3. Ахманова О. С. Словник лінгвістичних термінів// [Електронний ресурс]. - Режим доступу: http://www.classes.ru/grammar/174. Akhmanova/

4. Бєлова А. Д. Нові тенденції у вивченні мов і комунікації // Мовні і концептуальні картини світу // Збірник наукових праць. - Київ: Логос, 1999. - $176 \mathrm{c}$.

5. Бибик С. Нетикет або мережевий етикет// Культура слова № 82// Збірник наукових праць, 2015. - С. 125-128.

6. Столярова М. О. Етикет у віртуальній англомовній комунікації // Мовні і концептуальні картини світу // Збірник наукових праць. Київ: Логос, 2002. - 590 с.

7. Chis O. J. Electronic communication. Oxford, 1995. - $214 \mathrm{p}$.

8. Olderman R. O. Netiquette and Strategies for Efficient Use. - New York, 1997. - 114 p.

9. Partridge E. Slang today and yesterday with a short historical sketch :and vocabularies of English, American, and Australian slang. - London: Routledge\&KeganPaul, 1960. - 145 p.

10. Robert L. S. Electronic communication. - Oxford, 1991. - 324 p.

11. Sabath A. M. E-mail Etiquette Tips, At Ease Inc., Cincinnati: 1996. -215 p.

\section{Новікова Ірина}

(м. Острог, Украӥна)

Національний університет «Острозька академія»

\section{ІНШОМОВНІ ЗАПОЗИЧЕННЯ В АНГЛІЙСЬКІЙ ПРОЗІ} (на прикладі повісті Річарда Прескотта «Офіційно мертвий»)

У тезах проводиться аналіз іншомовних запозичень та визначення їхнього походження.

Ключові слова: запозичення, асиміляиія, словниковий запас, семантична група.

В тезисах проводиться анализ иностранных заимствований и определение их происхождения.

Ключевые слова: заимствования, ассимиляция, словарный запас, семантическая группа.

The research provides an analysis of foreign words in the English Language and defines the origin of these words.

Key words: borrowings, assimilation, vocabulary, semantic group.

Any culture in the world did not develop in isolation separated from other cultures. Definitely, each language interacts with other language, and as a result there is an exchange of cultures, and also an exchange of words. Borrowings are common for all languages and especially for countries with a huge number of populations. Problems of borrowings are the topic of many course papers today. Many scientists tried to define reasons and causes of entering particular words from one language to another. The problems of borrowing are always researched as it is always in the process, and new changes occur in this sphere from time to time.

During many centuries English interacts with many other languages that could not be influenced on its vocabulary. There were French, Latin, German, Italian, Norse and Greek languages which enriched

\footnotetext{
(с) Новікова Ірина, 2018
} 
English vocabulary with new words. The causes of transferring new words to the English were different: according to political situation, emigration, during wars, etc. The huge majority of English words is foreign and has different origin. Loanwords are used by Americans not only in everyday life but also in other spheres, and many authors use loanwords in English prose where the number of these words is numerous. Some words enrich English vocabulary and some are not important and don't play a significant role as similar words with the same meaning has already existed in English.

The purpose of the article is to define the role of borrowings and their origin in the English vocabulary and particularly in the English prose «Officially dead». Task of the article:

1) To find different reasons of entering foreign words into the English language.

2) To define the origin of borrowings in the story «Officially dead».

The object of the article is borrowings in the English language. The subject of study is the process and the condition of entering foreign words in the vocabulary of English language.

For the research of defining different types of borrowings in the English vocabulary and in the story «Officially dead» is used a historical method. Also there are used different etymological and other dictionaries.

The results of the research can be used while learning English and can be helpful for the other course papers. Relevance of the topic. Usually, scientists tell about the interaction of English vocabulary with other languages, making an accent on the influence of the English vocabulary in other languages, but at the same time it is worth to research a reverse process. There are also many borrowed words in English from German, France, Latin and others.

The role of loanwords or borrowings in different languages is different and depends on the concrete conditions of the development of each language. The percentage of borrowings in the Eng. lang. is miles higher than in other languages. If to compare with other languages, Eng. lang. had an opportunity to borrow loanwords due to the condition of the close contact with foreign conquerors who always changed each other on the British Isles and later due to the trade expansion and the colonist activity of the Englishmen. It is calculated that the amount of truly English words in the Eng. voc. is only 30\%.

The number $30 \%$ characterizes the amount primordial words in the voc. but do not show the result of the usage of these words. While this counting, there are founded such primordial words as have, he, on good, thing that are mostly used every day in conversation, and there are also such words as vehicle, fuselage, chauffer, neologism that are used very seldom. So if to count the percentage not due to the dictionary but due to the spoken lang., taking in consideration each word as many times as it occurs then the result would be completely different.

Usually, borrowed word gets one or several meanings of words that are semantically close to the borrowed one and that have existed earlier. There can be a rearrangement in the structure of content like any secondary important meaning can become the central and vice versa [1].

The story «Officially dead» itself contains plenty of borrowings of different origins. Mostly words are Latin, French, Old Norse, German, and Dutch. The majority of words were from Latin and French languages. Loanwords were transferring into English lang. in different period. For example, the majority of Latin and French words came during 1100-1450 and in other periods of time. Approximately, there are 200 borrowed words in the story. The majority of words are nouns (141) than adjectives (29) and verbs (27).

\section{Latin words that came into English during 1100-1450:}

Due to the semantic group there were the following political and economic vocabularies: persuādēre, 1505-1515, sēcrētārius (ML), 1350-1400, marcātus 1100-1150, papyrus, 1325-1375, documentum, 1400-1450, sēcūritas, 1400-1450, solūtiōn, 1325-375, organizātiōn, 1375-1425, monēta 1250-1300, dēcīsiōn, 1425-1475, accident, 1350-1400, mercātus, 1100-1150, administrativus + form administrat - 'managed', from the verb administrare (Mid 18th), alibi, 17201730, identic, 1610-1620, politia, 1520-1530, client - from the Latin word client, stem of cliēns.

\section{Words of French origin}

French words that came into English during 1100-1450 and belong to the cooking semantic group: 
Toster, 1350-1400, orange, 1300-1350, jus, 1250-1300, salade, 1350-1400, barre(n), barrer (v) 1175-1225, disner (OF), 1250-1300 [3].

Words that belong to the economic and political semantic groups:

Order - ordre, 1175-1225, question, 1250-1300, addresser, 13001350, officium, 1200-1250, compaignie (OF), 1200-1250.

\section{Words of Greek origin:}

Phōnế, 1865-1870, idiốtēs, 1250-1300,idéā, 1400-1450,npróblēma, 1350-1400, orphanós, 1425-1475, sýstēma, 1610-1620, métron, 1790-1800, Maggie (the female name) - from a Greek word meaning «pearl», John ( man»s name) - from Greek Iōánnēs.

Mostly Greek words are partially assimilated because of the combination of $\mathrm{ph}$ in the root of the word. There is also completely not assimilated word idea.

\section{Words of Norse origin and historical semantic group:}

Gunna, 1300-1350; lāgr, 1125-1175; hūsbōndi; skyrta, 1250-1300 lān, 1150-1200; mistake, 1300-1330; flōr, before 900

The majority of Norse words are completely assimilated (husband) and partially assimilated.

Learning history of English language, doing the careful analysis of loanwords in English and concretely in one English prose, I can make certain conclusions.

Foreign borrowings are one of the most important kind of enrichment in Eng. vocabulary. By studying and analyzing of loanwords, the attention of researcher must be concentrated not only on when and from which language they came but also on which evolution was done after and which changes were made in words that have already existed before. The majority of foreign words in English are obviously numerous as it can be observed on the example of the story «Officially dead» where words have the origin from many countries and the number of these words are extremely high and are presented almost in each paragraph.

Being familiar with numerous scientific works in the industry of lexicology, I join to the idea of those who considered that despite high percentage of different borrowings, English cannot be classified as a language of international origin or as one of Roman. A local element contains the enormous amount of words, and a grammatical structure remained inviolable.

So, lexical borrowings are one of the sources of creating new words. Studying them help to define difficulties of language processes, interlacing of the internal and external phenomena in a language, influence of the last on different lank of linguistic structure.

\section{References:}

1. Nikolenko A. G. English lexicology. - Vinnytsa: Nova Knyha, 2007. $-527 \mathrm{p}$.

2. Ginzburg R. S., Khidekel S. S., Knyazeva G. Y., Sankin A. A. A Course in Modern English Lexicology. - Moscow: Higher School Publishing House, 1966. -274 p.

3. Etymology Dictionary Thesaurus - [Electronic document]. - Access mode: http://www.dictionary.com/

4. Online Etymology Dictionary - [Electronic document]. - Access mode: https://www.etymonline.com 
англійської мови, метою яких $є$ формування та розвиток навичок усного мовлення в учнів початкових класів. Серед них: Л. Вороніна досліджувала ефективні методики викладання англійської

УДК $811.111: 371.3$

Новоселецька Світлана, Шапран Наталія

(м. Острог, Украӥна)

Національний університет «Острозька академія»

\section{МЕТОДИКИ ФОРМУВАННЯ НАВИЧОК УСНОГО МОВЛЕННЯ НА ЗАНЯТТЯХ $З$ АНГЛІЙСЬКОЇ МОВИ УЧНІВ ПОЧАТКОВОЇ ШКОЛИ}

У тезах аналізуються методичні принциипи сучасних методик і використання їх у формуванні навичок усного мовлення на заняттях з англійської мови у початковій школі.

Ключові слова: методичні принципи, проектна методика, комунікативна методика, інтенсивна методика

В тезисах анализируются методические принцииь современных методик и их использование в формировании навыков устной речи на занятиях по английскому языку в начальной школе.

Ключевые слова: методические приниипы, проектная методика, коммуникативная методика, интенсивная методика.

In this research modern methodological principles and the ways of forming and developing English speech at the elementary school classes are being studied.

Key words: methodological principles, project method, communicative method, intensive method.

Англійська мова - мова міжнародного спілкування, і вміння спілкуватися нею стало необхідністю у сучасному світі. Закон Президента України «Про оголошення 2016 року Роком англійської мови в Україні» поставив нові завдання пошуку ефективних методик формування навичок спілкування англійською мовою в учнів початкової школи, що є об'єктивною необхідністю.

В останні роки з'явилось багато праць як вітчизняних, так і закордонних вчених, присвячених вивченню методик викладання

(С Новоселецька Світлана, Шапран Наталія, 2018 мови, Дж. Річардс вивчав комунікативний підхід під час навчання спілкуванню англійською мовою, Н. Душкова досліджувала проектну методику, I. Максимова, I. Бім вивчали інтенсивну методику.

Як закордонні, так і вітчизняні вчені приділяють вивченню існуючих методик викладання англійської мови, які, в основному, призначаються для слухачів курсів, студентів або учнів старшої школи. Для того, щоб використовувати ці методики для формування навичок усного мовлення учнів молодшої школи, необхідно їх адаптувати до вікових особливостей цільової аудиторії.

Метою цієї статті є вивчення методичних принципів сучасних методик і використання їх у формуванні навичок усного мовлення на заняттях з англійської мови у початковій школі. Досягнення мети дослідження зумовило такі завдання: дослідити сучасні методики викладання англійської мови та їхні методичні принципи; дослідити вікові особливості дітей молодшого шкільного віку; вибрати методичні принципи методик, які сприятимуть формуванню навичок усного мовлення, звертаючи увагу на вікові особливості дітей; розробити проект та плани уроків для школярів молодшого шкільного віку (3-4 класи), що втілюватимуть вибрані методичні принципи.

Наукова новизна дослідження полягає в тому, що в ньому запропоновано використання методичних принципів методик відповідно до вікових особливостей цільової аудиторії; створення проекту-гри та планів уроків, базою для яких є відібрані методичні принципи сучасних методик та IКТ. Розроблену проект-гру та плани уроків можна застосовувати при формуванні навичок усного мовлення та лінгвокраїнознавчих знань на уроках 3 англійської мови учнів початкових класів загальноосвітніх середніх шкіл.

Досягнувши віку 6-7 років, в більшості випадків дитина вже готова до систематичного навчання у школі. Шестирічна/семирічна дитина уже є особистістю, оскільки вона усвідомлює власну 
поведінку, може порівнювати себе з іншими. Школяр відкриває для себе нове місце у соціальному просторі людських відносин $[1$, c. 200].

Перехід до шкільного віку характеризується значними змінами у діяльності, спілкуванні, відносинах дитини з іншими людьми. Навчання стає основною діяльністю дитини, змінюється стиль $\dddot{11}$ життя. Позитивне ставлення та інтерес молодших школярів до навчання залишатимуться незмінними, якщо у навчальному процесі значна увага приділятиметься індивідуальним відмінностям учнів та їх особистісному розвитку.

М. І. Алєксєєва, Л. І. Божович, С. О. Мусатов вказують на широкі соціальні мотиви навчальної діяльності, які пов'язані з усвідомленням молодшими школярами (на доступному для дітей даного віку рівні) їхньої суспільної ролі, а також на вузькі особисті мотиви - задоволення самолюбства, почуття власної гідності, намагання будь-що бути кращим в колективі однолітків [1, с. 245].

Й. Лінгарт, В. Паламарчук, О. Савченко, О. Скрипченко, Н. Співак здійснили класифікацію навчальних дій, де виділяються такі навчальні дії (уміння і навички): організаційні, інтелектуальні дії, комунікативні та інформаційні. Під організаційними діями розуміється підготовка до сприймання учнями навчального матеріалу, вміння працювати у потрібному темпі, уміння створювати необхідні умови для виконання домашніх робіт. Усі навчальні вправи варто диференціювати, орієнтуючись на розвиток операційних дій [3, с. 120].

Під результативними складовими навчання учнів ми розуміємо отримані знання, уміння, навички, психічний розвиток i вихованість учнів. Засновниками комунікативної методики є британські лінгвісти Х. Стерн, М. Халлідей та американські соціолінгвісти - Д. Хаймс, С. Савінгтон, М. Лабов. Посприяла розвитку комунікативної методики і Рада Свропи, здійснивши низку заходів, спрямованих на розробку програми інтенсифікації навчання іноземних мов [1, с. 9].

Досліджуючи використання комунікативної методики, Р. П. Мильруд та I. Р. Максимова вказували на необхідність набуття учнями міжособистісного досвіду для того, щоб у межах власних здібностей та соціального статусу успішно функціонувати в суспільстві. Комунікативна методика ставить учнів перед необхідністю здійснювати спілкування як складну багатокомпонентну динамічну цілісну мовленнєву діяльність [3, с. 17].

Формування комунікативної компетенції має починатися ще у початкових класах. Комунікативна методика, основа якої забезпечує природність комунікації, робить іiі легшою для учнів молодшої школи і пришвидшує процес формування навичок усного мовлення. Учні навчаються мистецтву іншомовної комунікації, спілкуючись. Відповідно до комунікативної методики, усі вправи та завдання повинні бути комунікативно виправданими дефіцитом інформації, вибором та реакцією. Матеріал використовується такий, яким реально користуються носії мови. 3 самого початку використання рідної мови на заняттях англійської мови обмежується [3, с. 20].

Оскільки і комунікативна, і проектна, і інтенсивна методики викладання англійської мови в основному зосереджуються на набутті учнями навичок говоріння, то для ефективного навчання учнів початкової школи усного мовлення ми пропонуємо об'єднати методичні принципи цих методик, враховуючи психологічні особливості школярів молодшого віку. У досліджених нами методиках викладання англійської мови: і проектної, і комунікативної, і інтенсивної метою є навчання учнів навичок усного спілкування.

Усі заняття ми пропонуємо будувати на принципі новизни комунікативної методики. Ми відмовляємось від заучування, натомість пропонуємо молодшим школярам цікаві ігри. Гра все ще залишається важливою діяльністю в житті дитини, для якої це не лише цікавий спосіб провести час, але й спосіб моделювання зовнішнього дорослого світу та спосіб моделювання взаємовідносин. Оскільки гра та навчання - основні види діяльності молодшого школяра, а перехід від одного виду діяльності до іншого - це взаємодія попередніх і наступних форм, то вибір гри як важливого прийому і оптимальної форми навчання усного мовлення на заняттях з англійської мови на початковому етапі є цілком виправданим [4, с. 124]. 
Новизна проявлятиметься і й використанні «енерджайзерів» - рухових ігор, що виконуються в ритм 3 англійськими словами, виразами та реченнями. Крім того, надання дітям можливості багато рухатись не лише співпадає 3 потребою віку, але й суттєво прискорює процес засвоєння англійської мови. Адже фізична активність, за дослідженнями фізіологів, тісно пов'язана 3 мовленнєвою, отже відбуватиметься формування навичок усного мовлення. Використання пісень на заняттях 3 англійської мови $\epsilon$ цілком вмотивованим, оскільки молодшим школярам легше запам'ятати фрази і слова, які будуть використовуватись у процесі спілкування. Процес комунікації неможливий без лексичної та граматичної бази.

Ми вирішили створити плани уроків, темою яких будуть традиційні свята, на яких учні розвиватимуть навички усного мовлення за допомогою вищезгаданих методик. Кінцевим продуктом проекту буде голосування, де учні визначать найцікавіше для них свято. Ми обрали такі традиційні свята: Хеловін, Різдво, Пасха та день Подяки. Варто зауважити, що такі уроки проводяться у день, коли святкується свято.

Отже, виокремлення методичних принципів сучасних методик викладання англійської мови відповідно до їх сумісності 3 віковими особливостями учнів молодшої школи уможливлює їх застосування для формування навичок усного мовлення учнів початкової школи, дозволить підвищити диференціацію та індивідуалізацію навчальної діяльності учнів, надати їм лінгвокраїнознавчих знань про англомовні країни, оптимізувати засвоєння мовних структур та граматичних правил, а також подолати монотонність заняття при формуванні мовленнєвої та комунікативної компетенції учнів при навчанні англійської мови.

Завдяки використанню прийомів заснованих на базі вибраних методичних принципів вдається зробити процес формування навичок усного мовлення цікавим для дітей, шляхом перетворення його на гру.

Метою вивчених методик є формування навичок комунікації на заняттях з англійської мови, однак складність навчання школярів молодшого шкільного віку усного мовлення англійської мови за вищезгаданими методиками полягає у необхідності врахування їхніх соціально-вікових особливостей. Тому для реалізації цих методик потрібно враховувати ступені сформованості особистості. Прагнення до пізнання світу через спілкування з іншими людьми, наявність вихідної мовної бази, інформаційного запасу.

\section{Лiтература:}

1. Richards J. Communicative teaching today / J. Richards. - Cambridge, 2006. -42 p.

2. Долинська Л. В. Вікова та педагогічна психологія: навч. пос. / Л. В. Долинська, О. В. Скрипченко, З. В. Огороднійчук. - Київ: Каравела, 2007. - 400 c.

3. Максимова I. Р., Мильруд Р. П. Сучасні концептуальні принципи комунікативного навчання іноземних мов / І. Р. Мильруд, Р. П. Максимова // Іноземні мови в школі. - 2000. - № 5. - c. 17-21.

4. Починок Т. В. Keeping the conversation ball going: практическое пособие / Починок Т. В. // Гомельский гос.университет им. Ф. Скорины. - Гомель: ГГУ им. Ф. Скорины, 2007. - 124 с.

5. Activity village: Make handicrafts and learn English [Електронній pecypc]. - Режим доступу: http://www.activityvillage.co.uk/

6. British council for kids: Teach and Learn English [Електронній ресурс]. - Режим доступу: http://learnenglishkids.britishcouncil.org/en/

7. Nickerson R. S. Teaching of thinking and problem-solving R. S. Nickerson. - San Diego: CA: Academic press, 1994. - 400 p.

8. Super simple learning: Teach English [Електронній ресурс]. - Peжим доступу: http://supersimplelearning.com/

9. Андрієвська М. В. проектування дидактичних ситуацій у навчанні молодших школярів 3 використанням комп'ютера: автореф. дис. канд. пед. наук.: 13.00.09 Теорія навчання / В. М. Андрієвська. - Харків, 2009. - 20 с.

10. Бабенко Т. В. Методика навчання англійської мови в початковій школі: навчальний посібник / Бабенко Т. В. - Київ: Арістей. - 2006. $220 \mathrm{c}$.

11. Березіна Т. В. Використання методу проектів на уроках англійської мови як засобу формування позитивного інтересу до іншомовної культури / Т. В. Березіна. - Режим доступу: collection. Edu.ru / attach / $17 / 11175$. Doc 
УДК $811.11 ’ 373.7$

Радчук Олена

(м. Острог, Украӥна)

Начіональний університет «Острозька академія»

\section{ФРАЗЕОЛОГІЧНІ ОДИНИЦІ ІЗ КОМПОНЕНТОМ-ЗООНІМОМ: СТРУКТУРНО-СЕМАНТИЧНИЙ АСПЕКТ \\ (на прикладі німецької та англійської мов)}

У тезах проводиться структурно-семантичний аналіз англійських та німечьких фразеологізмів із компонентомзоонімом.

Ключові слова: фразеологічна одиниия, компонент-зоонім, семантична структура, семантичні особливості, зоосемізми.

В тезисах проводиться структурно-семантический анализ английских и немецких фразеологизмов с компонентом-зоонимом.

Ключевые слова: фразеологическая единица, компонентзооним, семантическая структура, семантические особенности, зоосемизмы.

The research provides a structural and semantic analysis of English and German phraseological units with a component-zoonim.

Key words: phraseological unit, component-zoonim, semantic structure, semantic features, zoosemism.

Одним із найнеобхідніших і водночас найскладніших аспектів вивчення іноземної мови є вивчення лексики, оскільки саме слова, їх значення відіграють головну роль у передачі інформації, обміні думками та почуттями.

У семантичній структурі фразеологізму можна виділити різні типи значень, однак найбільшу складність для виокремлення та вивчення представляють переносні значення слів, тобто фразеологізми, які представляють трудність для розуміння не лише для тих, хто вивчає мову, але часто і для самих носіїв мови.
Фразеологізми займають особливе місце у словниковому складі німецької та англійської мов. Їх специфічна структура приваблює і викликає неабияку зацікавленість науковців, а 3 іншого боку вимагає серйозного аналізу змісту та форми мовних одиниць. Оскільки фразеологія як наука виникла лише на початку XX століття, багато вчених проводили дослідження теоpiї фразеології та отримали певні результати, зокрема В. В. Виноградов, Л. Г. Скрипник, М. Ф. Алефіренко, Л. Г. Авксентьєв, М. Т. Демський, В. П. Жуков, О. М. Мелерович та багато інших. Щодо вивчення фразеології в англійській мові, то цим питанням цікавилися такі відомі вчені-лінгвісти як О. В. Кунін, Н. М. Амосова, А. І. Альохіна, Ш. Баллі та Л. П. Сміт, а у німецькій - Ф. Зайлер, В. Корт, К. Зімрок, Г. Бюхман, Й. Ейзелейн, Ф. Тетцнер, Ф. Ліппергайд.

Отже, вивчення ФО та їх семантики (від грецьк. semantikos «той, що має значення»), зокрема їхнього семантичного аспекту на сучасному етапі при вивченні іноземних мов набуває особливо важливого значення.

На сучасному етапі вивчення фразеології важливого значення набуває необхідність дослідження фразеології з метою з' ясування рівня схожості та відмінності цих мовних явищ у різних мовах. Багато фразеологізмів мають повні або часткові відповідники у багатьох мовах, що пояснюється схожістю відображення реальної дійсності носіями різних мов та спільністю певних елементів культури.

Наприклад, нім. wie Hund und Katze leben - англ. live a cat and dog life - укр. жити як кішка з собакою; нім. Hunger haben wie ein Wolf-англ. as hungry as wolf-укр. голодний як собака.

Відносини «людина - тваринний світ», що розвиваються під впливом історичних, географічних і соціальних факторів, надають очевидний вплив на мову. Фразеологізми з компонентом-зоонімом володіють високим конотативним потенціалом і є одними 3 основних джерел культурно-національної спадщини народів. Все це, безумовно, становить актуальність нашого дослідження.

Новизна статті полягає в тому, що в ній здійснюється комплексний аналіз фразеологічних одиниць 3 компонентом-зоонімом 
як підсистеми фразеологічного фонду німецької та англійської мов за структурно-семантичним аспектом.

Мета статті - винайти, дослідити та порівняти вживання семантичних особливостей німецької та англійської мов шляхом аналізу фразеологічних одиниць 3 компонентом-зоонімом. Об'єктом дослідження є фразеологізми, які містять зоонім - назву тварини чи птаха - у німецькій та англійській мовах.

Завданнями науково-дослідницької роботи є: визначити, що таке фразеологія та фразеологізми; з'ясувати сутність терміну зоосемізм; прослідкувати використання зоосемізмів у німецькій та англійській та українській мовах; дослідити семантичну структуру зоосемізмів у німецькій та англійській мовах

Предметом $\epsilon$ семантичні та структурні властивості фразеологічних одиниць 3 компонентом-зоонімом. Теоретична значущість роботи полягає в аналізі такого типу фразеологізмів як зоосемізми у німецькій та англійській мовах, а також у визначенні та порівнянні їхньої семантики.

Практична значущість статті полягає в тому, що після дослідження отримані результати та зроблені висновки можна використовувати при написанні науково-дослідницьких робіт, теми яких пов'язані з фразеологією та її використанням. Для досягнення мети у статті використані аналітичний, описовий та порівняльний методи.

У цьому дослідженні ФО були класифіковані на основі домінуючих якостей характеру. Прагнучи охарактеризувати свою поведінку, почуття, стан, зовнішність, людина вдавалася до порівняння з тим, що було до неї найближче і схоже на неї саму тваринним світом.

Внутрішній зміст фразеологізмів відображає різноманітні сторони життя людей: розсудливу або дурну поведінку, успіх чи невдачу, і так само відносини між людьми: їх життєві враження і почуття: схвалення, несхвалення, дружелюбність, ворожість, сварки, примирення, суперництво, підступність, осуд, покарання [12]. В цьому аспекті нами було проаналізовано 30 фразеологічних одиниць із компонентом зоонімом (словосполучень і комунікативних фразеологічних одиниць):
- Обережність, передбачливість - 3 фразеологічні одиниці:

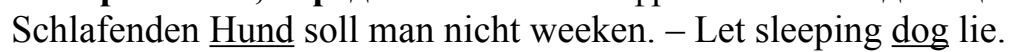

Wer mit Hunden schlafen geht, steht mit Flöhen auf. - If you lie down with $\underline{\text { dogs, }}$ you'll get up with fleas.

Rufe nicht « $\underline{\text { Hase }}$ » bis du ihn im Sacke hast - First catch your hare then cook him.

- Життєвий досвід - 4 фразеологічні одиниці:

Der frühe Vogel fängt den Wurm. - The early bird catches the worm.

Der Spatz in der Hand ist besser als die Taube auf dem Dach. - A bird in hand is worth two in the bush.

Die Katze im Sack kaufen. - To to buy a pig in a poke.

Wenn die Katze aus dem Haus ist, tanzen die Mäuse auf dem Tisch. - When the cat's away the mice will play.

- Працьовитість - 3 фразеологічні одиниці:

Arbeiten wie ein Pferd - Work like a horse.

Zwei Fliegen mit einer Klappe schlagen. - Kill two birds with a stone.

Den Stier bei den Hörnern fassen. - Take the bull by the horns.

- Жадібність - 3 фразеологічні одиниці:

Gierig wie ein Hamster. - As greedy as a pig.

Man soll das Fell des Bären nicht verkaufen, bevor man ihn geschossen hat. - Don't sell the skin till you have caught the bear.

Der Hund auf dem Heu. - A dog in the manger.

- Дурість - 3 фразеологічні одиниці:

Dastehen wie die $\underline{K u h}$ vorm neuen Tor. - Be at one's wit's end.

Den Bock zum Gärtner machen. - Teach the cat the way to the kirn.

Wie vom wilden $\underline{\text { Affen }}$ gebissen. - As stupid as a donkey.

- Впертість - 2 фразеологічні одиниці:

Störrisch wie ein Esel. - As stubborn as a mule.

Ein totes $\underline{\text { Pferd }}$ schlagen. - Flog a dead horse.

- Життєрадісність - 2 фразеологічні одиниці:

Wie ein Elefant nach dem Baden zufrieden. - Like the cat that ate the canary.

Frei wie ein $\underline{\text { Vogel. }}$ - As free as a bird.

- Лінь - 3 фразеологічні одиниці:

Auf der Bärenhaut liegen. - Play the $\underline{\text { ass }}$. 
Eine $\underline{\text { Katze }}$ mit Handschuhen fängt keine $\underline{\text { Mäuse. }}$ - A $\underline{\text { cat }}$ in gloves catches no mice.

Die Arbeit ist kein Falke, fliegt nicht fort in den Wald. - The work isn't going anywhere.

- Хитрість - 3 фразеологічні одиниці:

Schlau wie ein Fuchs. - As cunning/sly as a fox.

Bei Nacht sind alle Katzen grau. - All cats are grey in the dark.

Alter Fuchs kommt nicht zweimal ins Garn. - A fox is not taken twice in the same snare.

- Сміливість - 2 фразеологічні одиниці:

Tapfer wie ein Löwe. - As brave as a lion.

Sich in die Höhle des Löwen wagen. - To beard the lion in his den

Отже, ми спостерігаємо високу фразеологічну активність, такий мовний феномен пояснюється тим, що він - відображення або закріплення тісного і тривалого контакту людини з фауною, витоки якого, на думку О. Гаращенко, «йдуть у сиву давнину, до тих епох еволюції людини, коли анімалізм був основою світогляду. Тоді почали складатися перші узагальнення-символи, конкретизовані в образі певної тварини. Пізніше приручення тварин стало причиною нових форм символізації» [11].

Найбільш яскраво ментальність проявлясться у фразеології 3 компонентом-зоонімом. Тварини є мірилом багатьох людських якостей - як фізичних, так і моральних. І це не могло не відбитися і у фразеології різних народів. Люди помічали поведінку тварин, їх повадки і переносили ці властивості на людину, порівнювали поведінку тварин 3 поведінкою людей. При використанні назв тварин у фразеології народ частіше був схильний відзначати негативні риси, ніж позитивні.

У багатьох фразеологізмах одним з компонентів є зоонім ссавці, птахи, комахи, риби, ракоподібні, плазуни і черви.

Таким чином, фразеологічний склад англійської, німецької та української мови являє собою дуже цінну лінгвістичну спадщину, тому що саме в ньому відбивається культурно-історичний світогляд народу, його культура, звичаї, традиції, а фразеологізми зберігають і відтворюють його менталітет, його культуру від покоління до покоління.

\section{Література:}

1. Авксентьєв Л. Г. Семантична структура фразеологічних одиниць сучасної української мови та особливості її формування // Мовознавство, 1997. - № 3. - С. 77-83.

2. Єрченко П. Г. Класифікація фразеологічних одиниць // Іноземна філологія. $-1994 .-155$ с.

3. Карабан В. Теорія і практика перекладу з української мови на англійську мову - Вінниця: РТО, 2001. - 578 с.

4. Корунець I. В. Порівняльна типологія англійської та української мов. Навч. посібник. - Вінниця: Нова книга, 2003. - 458 с.

5. Чернышева И. И. Немецкая фразеология и принципы ее научной систематизации. - Москва: Русский язык, 1975. - 656 с.

6. Прокольєва С. М. Механізми створення фразеологічної образності. - Москва, 1996. - 260 с.

7. Гаврись В. І. Німецько-український фразеологічний словник в двох томах. ТОМ 1. - Київ, 1981. - 213 с.

8. ODCIE (Oxford Dictionary of Current Idiomatic English). - Oxford, 1988. $-396 \mathrm{p}$. 


\section{Савіцька Аліна}

(м. Острог, Украӥна)

Національний університет «Острозька академія»

\section{МІФІЧНІ СТВОРІННЯ У ФОЛЬКЛОРІ АНГЛОМОВНИХ КРАЇН}

У статті основну увагу зосереджено на міфічних створіннях у фольклорі англомовних краӥн, їхньому походженні та оригінальних функиіях. Розглянуто природу міфу, його інтерпретацію та розуміння людьми.

Ключові слова: міфологія, міф, варіативність, фольклор, світосприйняття, релігія, інтерпретація.

В данной статье сосредоточено внимание на мифических созданиях в фольклоре англоязычных стран, их происхождении и оригинальных функииях. Рассмотрено природу мифа, его интерпретации и понимание людьми.

Ключевые слова: мифология, миф, вариативность, фольклор, мировосприятие, религия, интерпретация.

Mythical creatures were analyzed in folklore of English-speaking countries. The focus is on their origins and initial features. We also explored the nature of the myth, its interpretation and understanding by people.

Key words: mythology, myth, variability, folklore, world perception, religion, interpretation.

Метою статті є охарактеризувати міфічних створінь у фольклорі англомовних країн. Завданням є обгрунтування загальної характеристики міфу та міфічних істот фольклору англомовних країн. Об'єктом статті $є$ фольклор та міфічні створіння англомовних країн, предмет - міфічні істоти у вищезгаданому фольклорі. Актуальність дослідження полягає в тому, що міфологія має свою логіку, функції, певним чином впливає на суспільство та людей, пояснюючи їм різноманітні явища та суть певних ре- чей. Дуже важливо вивчати міфи, дійти до суті, знати походження та судження про речі. Багато сюжетів книг, їх персонажів, а в подальшому і фільмів напряму зв'язані з фольклором, адже саме 3 них автори та сценаристи черпають своє натхнення. Саме для того, щоб полегшити розуміння про ці речі, було проведено дане дослідження. У написанні даної статті найбільше допомогли книги Блакуела «Міфологія для «чайників»»» і Г. В. Щеглова «Міфологічний словник». Також корисним джерелом інформації послужила книга філософа і історика Мірчі Еліаде «Аспекти міфу».

У роботі були застосовані наступні методи дослідження: порівняння, абстрагування, аналіз та синтез, історичний.

Здавна міфи були джерелом натхнення та ідей для багатьох авторів, письменників, режисерів тощо. Це і не дивно, адже міфологія завжди пояснювала багато суспільних, релігійних, історичних подій, даючи людям все більше матеріалу для нових оповідок, адже міф ніколи не мав конкретної версії; одна розповідь могла мати біля сотні варіантів. Герої, боги, створіння мають різний опис, функції, історію у різних народів світу. Дуже важливо вивчати міфи, дійти до суті, знати походження та судження про речі.

Перед тим як починати говорити про власне міфічних створінь, варто уточнити, що ж таке міфологія. Міфологія (від грецької «mythos» - історія людства, «logos» - слово або промова, «mythology» - усна розповідь про людство) - наука та інтерпретування часто священних історій або байок певної культури. Збірка історій, в яких оповідають про людське життя, добро і зло, походження людства, життя та смерть, загробне життя та богів. Семенов зазначає, що «в сучасній літературі слово «міфологія» вживається в трьох значеннях:

- Міфологія як сукупність переказів, сказань, розповідей про богів і героїв, їх походження життя, діяння т. д.

- Міфологія як система фантастичних уявлень про світ, що включає в себе безліч різноманітних міфів, які можуть бути типологізовані.

- Міфологія як наука про міфи, їх природу, сутність, походження, функції і т. д. [1, с. 74]. 
Міфологія намагається відповісти на найбільш складні базові запитання людського існування. В древності значення історії було найважливішим, а буквальна правдивість деталей цих, можна сказати, казок, відходила на другий план. Метою міфу було надання людині певної інформації, яка б дозволила інтерпретувати її в свою, особисту, правду. Навіть зараз стародавні міфи резонують 3 сучасністю, бо автори писали так, щоб істина прожила віки, і щоб нащадки все ще розуміли і знаходили для себе відповіді на хвилюючі їх запитання. Міфологія є найбільш древнім, архаїчним, ідеологічним утворенням, що має синкретичний характер. В іiі основі закладені анімістичні уявлення, тобто віра в існування духів та в душевність всієї природи. Це вказує на тісний зв'язок міфології $з$ релігією. Проте, варто звернути увагу на унікальність міфологічного сприйняття світу. Міфологія не є тотожною філософії, хоча в ній ми бачимо осмислення глобальних проблем життя; міфологія не являється літературним жанром, хоча в ній можна побачити поетичні образи; міфологія не тотожна релігії, хоча включає в себе різні культури та обряди, присвячені богам; міфологія не є історичним сказанням, хоча береже пам'ять про важливі історичні події. Можна зробити висновок, що міф - це і перше, i друге, третє четверте, і дещо більше, щось абсолютно унікальне - перша світоглядна система, призначена відповісти на різноманітні запитання, і тому включає в себе настільки суперечливі компоненти. Подібна унікальна універсальність дозволила Крістоферу Блакуелу зробити цікавий та несподіваний висновок, з яким можна погодитись: «Міф - це диво»[2, с. 368]. Міф розповідає про різні речі, і від цієї схильності до універсальності можна побачити його полі функціональність. Одна 3 його головних функцій - бажання пояснити той чи інший предмет, явище, етіологія(грец. «причина», «підстава») міфу ховається в його природі.

М. Еліаде наголошує на моделюючій функції міфу: «Роль міфу в структурі всього людського існування не можна виміряти Завдяки міфу концепт реальності, значущості, трансцендентності крок за кроком проявляє свою суть. Завдяки міфу, світ сприймається як досконало впорядкований, розумний і значимий Космос» $[3$, с. 56].
Найцікавішими об'єктами для даної статті є міфічні створіння, які з часом набули все більших варіацій та описів.

Перш за все, Банші (англ. Banshee; від ірл. bean sídhe - жінка з Ші) - персонаж ірландського фольклору, чий крик був вісником смерті. Цей крик називають «саoine», перекладається як «плач, туга за небіжчиком». За словами Тетяни Михайлової: «Різні легенди описують це створіння по-різному: одні кажуть, що це молода дівчина з білосніжною шкірою та довгим червоним волоссям, інші ж стверджують, що вона виглядає як стара жінка 3 рідким сивим волоссям, гнилими зубами і червоними злими очима» [4, с 47]. Часто їі зображують з гребенем у волоссі. В Ірландії через це виник забобон, що знайти гребінь на землі - до нещастя. В Шотландії існує аналог ірландській Банші - Банніє, або «маленька прачка біля ставу». Виглядає вона як сільська жінка, що несе в руках закривавлені ганчірки, які планує прати в ставку. Там вона радше демон, коли в Ірландії ії більше приймають за фею. Існує пояснення того, чому Банші з'являється перед людьми саме в образі жінки: в книзі Буття Сва подає Адаму яблуко; в християнській легенді Марія подарувала світові Христа; в Стародавній Греції саме жінки передавали повідомлення від Богів смертним. Жінки приводять дітей в світ. І саме тому Банші - це ті, хто повідомляє людей про смерть, яка наче пророкує душі нову подорож.

Наступне створіння, варте уваги - Богарт (англ. Boggart; ще один укр. варіант - ховчик) - дух або домовий в англійській міфології. Схожі створіння відомі в США під ім'ям Бугі або Бугімен. В Шотландії їх називали Бігле, в Німеччині - Боглеман. Істота на подобі полтергейста, невидима, проте може приймати різні форми. Так як кожного разу він набуває іншого вигляду, конкретного опису цього створіння не існує. С два типи богартів: перші - ті, які можуть приймати людський вигляд, інші ж ті, що матеріалізуються як тварини. Людиноподібні богарти зазвичай жорстокіші, ніж інші. Вони дуже люблять розігрувати людей - лякати їх, грюкаючи дверима, переміщаючи речі, розливаючи молоко або ж ховаючись в темних місцевостях і тероризуючи туристів. Проте, якщо задобрити це створіння, воно може виконувати певну хатню роботу і допомагати в господарстві. 
Останні, які варті уваги, та наймеш відомі - Більвізи - злісні деревні духи, що живуть всередині дерева. На великих пальцях лівої ноги в них серпи замість нігтів. 3'являються вечорами, вдягнуті в полотняні одежі. Вони особливо небезпечні у Вальпургієву ніч (1 травня). Ці створіння спустошують поля, дражнять людей, всіляко капостять. А на тих, хто забираються в поля, що охороняються бельвізами, вони насилають прокляття «ельфійський удар» - певного роду параліч.

Отже, було розглянуто міфічних створінь у англійському фольклорі, шукаючи їх походження, оригінальні образи, функції тощо. Міф по своїй природі $є$ варіативним; один міф може налічувати до сотні варіантів та переказів. Він дозволяє людям робити власні висновки, шукати свою істину та інтерпретувати для себе, розвиваючись тим самим у соціальному, історичному, релігійному планах. Саме тому важливо знати походження міфу, його первинний варіант. Автори-фантасти використовують багато істот з різних міфологій у своїх книгах, можна сказати, переносять їх в сучасність, змінивши деякі факти, властивості, здібності та інколи надаючи створінням трохи іншого вигляду. 3 одного боку, це позитивно впливає на читача, адже це явище дає людям розвивати свою фантазію, виходить за межі стандартного списку істот в літературі, що є всім знайомими та вважаються у певному роді «кліше». Проте, з іншого боку, ці зміни можуть плутати неосвіченого читача, навчивши його новим стандартам, заставляючи забути про старі та оригінальні міфи, які, хоч і є варіативними, проте мають свої індивідуальність та походження.

Узагальнюючи сказане, ми визначили природу певних істот у англійському фольклорі, цим самим дійшли до їх початкових версій, першоджерел, що надало нам глибше розуміння цих створінь, їх характеристик.

\section{Лiтература:}

1. Семенов Ю. И. Тотемизм, первобытная мифология и первобытная религия // Скепсис. № 3/4. - Весна. - 2005. С. 74-78.

2. Кристофер У. Блакуэлл, Эйми Хакни Блакуэлл Мифология для «чайников» (Mythology For Dummies) - Москва: Диалектика, - 2006. «Диалектика»-368 c.
3. Элиаде М. Аспекты мифа / Мирче Элиаде. - Москва: Академический проект, 1963. - 251 с.

4. Патриция Лайсафт, Татьяна Михайлова, Банши. Фольклор и мифология Ирландии. - Москва: ОГИ, 2007. - 47 с.

5. Щеглов Г. В. Мифологический словарь / Геннадий Васильевич Щеглов. - Москва: Астрель, - 2007. - 368 с. 
УДК $81 ’ 373.612 .2$

\section{Соломчук Ольга}

(м. Острог, Україна)

Начіональний університет «Острозька академія»

\section{МЕТАФОРА I МЕТОНІМІЯ ЯК ЗАСОБИ ТВОРЕННЯ ОБРАЗНОСТІ}

У тезах проаналізовано основи семантичної класифікації метафори і метонімії в літературі на матеріалі англійської мови. 3'ясовано види метафор та їх роль в англійській мові, проаналізовано контекстуальне стилістичне значення метафор і метонімій.

Ключові слова: метафора, традииійні теорії метафори, метонімічний перенос, метонімічні зв'язки, антономазія.

В тезисах проанализированы основы семантической классификации метафоры и метонимии в литературе на материале английского языка. Выяснено виды метафор и их роль в английском языке, проанализировано контекстуальное стилистическое значение метафор и метонимий.

Ключевые слова: метафора, традиционные теории метафоры, метонимический перенос, метонимические связи, антономазия.

The research analyzes the basics of the semantic classification of metaphor and metonymy in the literature on the material of the English language. There were explored the kinds of metaphors and their role in the English language and the contextual stylistic meaning of metaphors and metonymy was analyzed.

Key words: metaphor, traditional theories of metaphor, metonymic transfer, metonymic connections, antonomasia.

Явище метафоричності, як і метонімії завжди привертали увагу науковців. Перш за все, це обумовлюється інтересом до детального вивчення тексту в усіх його аспектах, прагненням пояснити з лінгвістичної точки зору стилістичні прийоми і їх вплив на текст. Привертають увагу дослідників і проблеми, пов'язані 3 творенням експресивності мови. В основі метафори і метонімії лежить перенесення назви з одного предмета (явища, дії, ознаки) на інший. Проте ці два тропи відрізняються один від одного: метафоричне перенесення здійснюється на основі подібності, а метонімічне - на основі суміжності.

В останні десятиліття інтерес до їх дослідження суттєво підвищився (сучасні концепції метафори почали виникати з 90-х років XX століття), як і зріс інтерес українців до англійської мови. Останнє пояснюється економічними відносинами з англомовними країнами, появою мережі Інтернет та поширенням програм обміну.

Одним з найвищих показників опанування мови є вміння аналізувати текст, адже воно полягає в здатності знайти і зрозуміти вжиті стилістичні засоби, а також в розумінні культури народу автора. Все це сприяє логічному мисленню, аналітичним здібностям і розширенню знань іноземної мови.

У тезах основоположними є точки зору таких лінгвістів як I. В. Арнольд, А. Вежбицька, Л. В. Кравець, О. Е. Корольова, Дж. Лакофф, М. Джонсон, А. Гаверкамп, Г. Радден та ін.

В ході дослідження були використані такі методи, як: аналіз, дедукція і порівняння. Мовні засоби посилюють вагомість висловлювання завдяки додаванню експресивних відтінків до його суто логічного змісту. Таке посилення виразності досягається найчастіше використанням тропів. Троп, згідно зі Словником літературних термінів, укладеним Г. Шоу, - це будь-який літературний риторичний механізм, суть якого полягає у використанні слів у значенні, що відрізняється від буквального сенсу [10, с. 9].

Одним із важливих завдань дослідження художнього дискурсу $\epsilon$ вивчення функціонального призначення метафоричних найменувань, оскільки саме метафора дає змогу пізнавати нові якості речей, формувати нову експресивну лексику. Метафора - це троп, що базується на використанні слова, що позначає деякий предмет (явище, дію чи ознаку), для характеризування (чи найменування) іншого предмета на основі подібності, яка існує в реальній дійсності або в уяві мовця [3, с. 30]. При чому уподібнення одного 
предмета до іншого базується на схожості варіативних ознак: зовнішнього вигляду, розміщення в просторі, функції, структури, оцінки чи навіть вражень, які вони викликають. У лінгвістику метафора була запозичена 3 риторики, для якої вона слугувала засобом образотворчої мови й естетики. Ще античним вченим і філософом Арістотелем було проведено перше найбільш відоме і значуще дослідження сутності метафори.

Існуючі класифікації охоплюються семантичними і структурно-граматичними критеріями. За структурою розрізняють прості та розгорнуті метафори [1]. Проста (однокомпонентна) метафора завжди виражена одним образом, проте не обов'язково одним словом: she is an angel (angel = lovely person). Розгорнута (багатокомпонентна) метафора складається з кількох метафорично вжитих слів, що створюють єдиний образ, тобто, це ніби взаємозв'язок простих метафор: the ball happily danced into the net.

Традищійними називають метафори, загальноприйняті в якийсь період чи в якомусь літературному напрямку. Вони часто зустрічаються у літературі та мовленні, тож згодом перетворюються у кліше: eyes - stars, lips - coral, «slippery slope». Використання у розмові таких метафор створює враження поетичного мовлення, іноді чудернацького - 3 іронічним відтінком.

При поділі за функціями виокремлюють наступні різновиди метафор: власне метафори, метафора-епітет, метафора-порівняння, метафора-перифраз, метафора-уособлення, метафора-символ, метафора-алегорія.

Проте, базовою вважається така класифікація:

- різка метафора - об'єднує слова з віддаленими поняттями, грунтується на контрасті;

- стерта метафора - настільки загальноприйнята, що втратила свою метафоричність - (ніжка стола, вушко голки, чутки ходять);

- метафора-формула - близька до стертої метафори, але формулу вжити у прямому значенні неможливо;

- композиційна (сюжетна) метафора становить особливий інтерес через те, що може поширюватись на весь роман. Іншими словами, художній твір конструюється на основі заміни одної ідеї чи повідомлення на інше через уподібнення, тобто метафорично. До прикладу, «Улісс» Джеймса Джойса;

- реалізована метафора передбачає буквальне розуміння значень слів-складових метафори, акцентування на прямому значенні слів;

Існують й інші погляди на класифікацію метафор. Наприклад, Дж. Лакофф і М. Джонсон виділяють 2 типи метафор: онтологічні, тобто метафори, що дозволяють бачити події, дії, емоції, ідеї та ін., і орієнтовані, тобто метафори, що не визначають один концепт у термінах іншого, але організують всю систему концептів у відношенні один до одного [5].

Образність - не є єдиною метою вживання метафори. Аналіз функцій метафоризації, проведений в роботах А. Вежбицької [2], дозволяє виокремити наступні функції метафоричних утворень в мові:

- естетична функція - наділення мови виразністю, породження відчуття новизни, відображення суб'єктивного ставлення мовця до ситуації;

- пізнавальна функиія - відображення одночасно і ясності, i певної урочистості висловлювання, чітка і логічна побудова думки, що дозволяє уникнути в багатослів'я у висловах і сприяє їх лаконічності;

- оціночна функція - створюється один цілісний образ, який виражає позитивні чи негативні характеристики слів, укладених в кожній метафорі;

- психологічна функиія - занурення в процес сприйняття людиною світу з точки зору «психічного будови особистості», спираючись на власний психологічний стан.

Щодо функціональної значущості метафори в художньому мовленні лінгвісти дотримуються думки про те, що метафора одночасно виконує три функції: інформативну, що визначає об'єктивність передачі інформації про значення ознаки через образні мовні структури; образну, що полягає в кодуванні метафорою основного значення предмета чи явища, за рахунок чого і породжується художній образ; символістичну, яка допомагає правильно побачити зашифровані знаки і вловити настрій автора. 
Художній дискурс початку XXI століття - це багатостильова образно динамізована площина, у якій активно функціонує метафора, яка виконує образотворчу, стилістично-описову, емоційно-експресивну, зображально-оцінну, внутрішньоаксіологічну функції, які не лише увиразнюють художній текст, а й сприяють вираженню оцінки зображуваних явищ, внутрішнього стану персонажів.

За граматичним вираженням метафор серед них виділяють кілька типів: субстантивні, атрибутивні, дієслівні, комбіновані.

- Субстантивні поділяються на кілька видів:

- загальномовні одночленні іменникові метафори, образність яких стерлася: вічко (у дверях), вікно (між уроками);

- двочленні іменникові метафори: свято душі, муки творчості;

- тричленні іменникові метафори, в яких образність виникає на нанизуванні лексем: волею богів естет.

- Атрибутивні метафори мають дві основні граматичні форми вираження - прикметник, дієприкметник та прислівник. Атрибутивні метафори називають ще метафоричними епітетами: калинова мова.

- Дієслівними метафорами називають такі, в яких один член виражений дієсловом 3 переносним значенням. Переносність значення сприймається виключно на рівні його сполучуваності 3 іменником (першим членом метафори): Широкий Дніпр не гомонить; Вітер з гаєм розмовляє.

Метонімія (грец. «перейменування») - згідно з Літературознавчим словником-довідником, один 3 основних тропів у поетичній і звичайній мові, в основі якого лежить перенесення назви одного поняття (класу об'єктів чи одиничного об'єкта) на інше, що перебуває з ним у певному зв'язку; слово або вираз, ужиті таким чином [6]. Основою метонімії можуть служити просторові, логічні, подієві та інші зв'язки між різноманітними категоріями, що належать дійсності чи її відображенню в людській свідомості. Ці зв’язки будуються між предметами, особами, діями, подіями процесами, явищами, місцями, часом та ін. До прикладу, to drink a glass, де glass означає міру рідини.
Механізм метонімії приводить до появи контекстуально нового значення слова. Основою метонімії можуть служити зв'язки між однорідними і неоднорідними категоріями, наприклад, предметами та їх ознаками. Отож, назва може бути перенесена:

- $з$ посудини, упаковки на вміст або об'єм вмісту: The kettle is boiling;

- 3 матеріалу на виріб з нього і навпаки: The maid is cleaning silver;

- 3 цілого на частину і навпаки: Hands wanted;

- $з$ предмета на поняття: From cradle to grave;

- 3 матеріалу на результат дії, виконаної з його допомогою: Paper - папір для письма i paper - письмовий документ;

- 3 місця, населеного пункту на його населення чи подію, що там відбулася: Pearl Harbor took place on December 1941;

- 3 соціальної організації, установи на їх колектив: The University applied for over 5.5 million Euros;

- $з$ соціальної події, заходу на його учасників: Congress voted against the legislation;

- $з$ місця на ту дію, для якої воно призначено: road - місце для пересування і road - подорож, поїздка;

- 3 дії на результат: to stop - зупинятися; a stop - місце зупинки;

- 3 імені автора на назву його твору чи його стиль: I spent the evening reading Shakespeare;

- 3 матеріальної форми, що містить зміст, на сам зміст: heavy book - про предмет; interesting book - про зміст;

- 3 галузі знання на її предмет: grammar - сукупність правил певної мови, її структура; grammar - розділ мовознавства, що вивчає структуру мови.

Суть метонімічних перейменувань в тому, щоб зосередити увагу на більш зрозумілих нам предметах. Як можна помітити 3 вищезазначеного, в ряді випадків метонімія є зворотною, тобто може розвиватись в обох напрямках. Вищеназвані зв'язки групуються науковцями на три види:

1. Просторова метонімія, яка базується на фізичному положенні предметів чи явищ: the hall applauded, де приміщення 
означає людей в ньому. До просторової метонімії належать також приклади переносу назви посудини на вміст.

2. Часова метонімія відбувається, коли результат називається дією, завдяки якій цей результат був досягнутий. До прикладу, «book edition» - дія, процес видання книг і «luxurious edition» результат дії.

3. Найпоширенішою є метонімія логічна. До неї відноситься решта типів зв’язків з попереднього списку.

Науковці визнали поділ метонімічного переносу на основі асоціацій. Вони виокремлюють метонімічний епітет, синекдоху та антономазію [3].

- Метонімічний епітет - зв'язок між предметом і одним 3 його ознак. Такі епітети є якнайбільш яскравими: «The yellow boots wandered down the street with her friend». Предмети гардероба дівчини мовець переніс на носія цих предметів. Такий епітет грає і функційну, і естетичну роль. У літературі відображає культуру, менталітет і особистий світогляд автора.

- Найчастіше у літературі та мовленні відбувається перенесення назви з частини на ціле чи навпаки. Цей вид метонімії називається синекдохою: a fleet of 50 sails - флот з 50 кораблів. Основна функція - ідентифікувати об'єкт через характерну для нього деталь, особливу ознаку. These wheels will drive you at your pleasure, де wheels використано замість car. Зазвичай синекдоха надає висловлюванню певної експресії.

Існує цілий ряд різновидів синекдохи, кожен з яких певною мірою заснований на генералізації (розширенні) чи конкретизації (звуженні) вихідного значення. Серед видів семантичного переносу виділяють наступні:

- Частина замість цілого: «hey, beard» (звертання до людини 3 бородою).

- Ціле замість частини: «to buy a fox» (мається на увазі хутро).

- Видове поняття замість родового: the press в значенні «всі засоби масової інформації, що передають останні новини», включаючи мережу Інтернет, радіо і телебачення, хоча спочатку the press вживалося на позначення лише частини 3MI - сукупності друкованих періодичних видань.
- Родове поняття замість видового: «the police knocked down my door», де the police означає групу поліцейських, які представляють інтереси поліції і закону в цілому.

- Однина замість множини: «The Lord's Eye».

- Антономазія - між власними і загальними назвами, які мають спільну змістову ознаку. До прикладу, вживання The Fab Four для позначення групи Beatles чи The Big Apple - для міста Нью-Йорк.

Таким чином, виокремлюють два типи антономазійної взаємодії:

- загальна назва стає іменем/власною назвою;

- імена, що «говорять самі за себе» виникають з асоціацій - ми логічно виділяємо, позичаємо властивості предмета: Sir Silvercup - сер Срібна Чашка;

- ім'я/власна назва стає загальною. The Byron of our days - Байрон наших днів, при чому є випадки написання імені як з великої, так і з малої літери.

Отож, метонімія створює або посилює яскравість бачення предмета. Вона є способом непрямої характеристики того чи іншого явища. На відміну від, наприклад, порівняння, метонімія відкидає всі ознаки і характеристики предмета, окрім характеристики, що є основною для конкретної ситуації. Крім того, метонімія належить до засобів локального вжитку, бо вважається раціональною лише у певному контексті. Це їі відрізняє від нейтральних слів та від метафоричних висловлювань [9, с. 6].

Підбиваючи підсумки, варто зазначити, що всі основні цілі були досягнуті, і задачі були виконані. Мовна природа метафори і метонімія була з'ясована. Тобто, ми визначили метафору як троп, що базується на використанні слова, що позначає деякий предмет (явище, дію чи ознаку), для характеризування чи найменування іншого предмета на основі подібності, яка існує в реальній дійсності або в уяві мовця.

Було розглянуто найпоширеніші класифікації метафори: поділ за структурою (на одно- та багатокомпонентні), за функціями (власне метафори, метафора-епітет, метафора-порівняння, мета- 
фора-алегорія та ін.) і її базову класифікацію, яка розрізняє різку, стерту, композиційну, реалізовану та метафору-формулу.

Також ми виявили найбільш загальні положення визначення метафори і визначили іiі основні функції: естетичну, пізнавальну, оціночну, психологічну, інформативну та інші.

Відповідно до перелічених в роботі тринадцяти категорій, між якими виникають метонімічні зв'язки, ми виділили три види метонімії: просторову, часову та логічну.

Ми дослідили найпоширеніші види метонімії - антономазію, синекдоху і метонімічний епітет. Найбільш уживаною $є$ синекдоха - термін означає перенесення назви з частини на ціле чи навпаки у літературі і мовленні.

Найбільша складність полягала в тому, що аналізовані у роботі тропи мають багато різновидів і перехідних типів, що зближають їх між собою і з іншими тропами. В окремих випадках, виникали труднощі у трактуванні переносного значення тропів через суб'єктивне світобачення автора.

\section{Лiтература:}

1. Арнольд И. В. Стилистика. Современный английский язык. Москва: Флинта, Наука. $-2002 .-384$ с.

2. Вежбицкая А. Семантические универсалии и описание языков. Москва. - 1999. - 453 с.

3. Кравець Л. В. Метафора і метонімія - два центри тропеїчної системи. //Культура слова. - 2000. - №55 - 56. - С. 30 - 36.

4. Королева О.Э. Метонимия как тип значения: семантическая характеристика и сферы употребления. Обнинск: Институт муниципального управления, 2002. - $158 \mathrm{c}$.

5. Лакофф Д., Джонсон М. Метафоры, которыми мы живём. - Москва: Едиториал УРСС, 2004. - $256 \mathrm{c}$.

6. Літературознавчий словник-довідник / О. Астаф'єв, 3. Бичко, Б. Бірчак і Д. Бучко; За ред. Р. Гром’як, Ю. Ковалів і В. Теремко. - 2-е вид., доп., випр. - Київ: Академія, 2006. - 752 с.

7. Haverkamp A. Metapher. Die Ästhetik in der Rhetorik. - München: Wilhelm Fink Verlag, 2007. p. 182.

8. Panther, Klaus-Uwe \& Günter Radden. Metonymy in Language and Thought. Amsterdam: John Benjamins. - 1999. - P. 410.

\section{Тилько Анастасія}

(Острог, Україна)

Наиіональний університет «Острозька академія»

\section{ХАРАКТЕРИСТИКА ЛЕКСИЧНИХ ЗАСОБІВ НА ПОЗНАЧЕННЯ НЕГАТИВНИХ ТА ПОЗИТИВНИХ ЕМОЦЙ (на матеріалі книги Джона Гріна «Паперові міста»)}

Тези присвячено дослідженню лінгвістичних особливостей та лексичних засобів вираження емочій на матеріалі англійської мови. Застосовано лексичний аналіз для вивчення тексту, а також для інтерпретації лінгвістичних одиниць, які висловлюють основні емочії автора. Визначено засоби вираження позитивних та негативних емоиій.

Ключові слова: емотивність, емотиологія, лінгвістика, емоиії, емоиійність.

Тезисы посвящены исследованию лингвистических особенностей и лексических средств выражения эмочий на материале английского языка. Применен лексический анализ для изучения текста, а также для будущей интерпретации лингвистических единии, выражающих основные эмочии автора. Определены средства выражения положительных и отрицательных эмоичий.

Ключевые слова: эмотивность, эмотиология, лингвисти$к а$, эмоции, эмоциональность.

The article is devoted to the study of linguistic features and lexical means of expressing emotions on the material of the English language. A lexical analysis was used to study of the text as well as for the future interpretation of linguistic units expressing the author's basic emotions. The means of expression positive and negative emotions are defined.

Key words: emotiveness, emotiology, linguistics, emotions, emotionality. 
Об'єктом дослідження $є$ текст книги Джона Гріна «Паперові міста». Предметом дослідження $є$ подача лексичних засобів вираженням емоцій у книзі Джона Гріна «Паперові міста».

Мова $є$ основою спілкування і вона не тільки забезпечує обмін інформацією, а також відображає емоційний стан мовців під час розмови. Емоції складають пізнавальну та мотиваційну сфери життя людини, та супроводжують ії протягом усього життя. Поряд 3 мовленнєвими засобами на емоційність спілкування також впливають жести, паузи, різна інтонація, рухи тіла і т.п., тому питання співвідношення емоцій та мови $є$ актуальним у сучасному мовознавстві. $€$ безліч теорій виникнення емоцій, але найбільш відома це теорія Ч. Дарвіна, який стверджував, що емоції виникли в процесі еволюції. Це засіб, за допомогою якого людина робить певну оцінку будь-яких умов для задоволення своїх потреб.

Однією з найважливіших властивостей мови $є$ ії̈ здатність виражати емоції. Темі вираження почуттів в мові приділяли велику увагу більшість дослідників. Як ми знаємо, емоції - особливий клас психічних станів, які відображають ставлення людини до навколишнього світу, до інших людей, до самої себе та до результатів своєї діяльності. Комунікативна здатність є найважливішою їхньою особливістю. Вони присутні у комунікативній діяльності людини, а також можуть відображатися на всіх рівнях мови. Мовлення $\epsilon$ найбільш важливою формою вираження емоцій людини.

Емоції поділяють на два основні види: негативні та позитивні. Існує сучасна теорія диференційованих емоцій К. Ізарда, яка полягає в тому, що кожна людина, з власного досвіду переконується, що вона відчуває саме печаль, щастя або ж страх. Можна дійти висновку, що емоції відрізняються за зовнішнім виглядом людини, тобто яким чином вона їх виражає, а також за внутрішнім переживанням.

Зміну емоцій ми можемо спостерігати завдяки деяким зовнішнім вираженням, зокрема це міміка та голосові реакції. Найвиразніше зміну почуттів ми можемо побачити в очах та в голоci. У повсякденному житті люди часто використовують виразні зовнішні рухи для визначення в емоційному стані, тих, хто нас оточує. Тобто, лексика пов'язана не тільки з психологією, а ще з багатьма науками, в цьому випадку біологією. П. Є. Клобуков дослідив, що емоції можна вважати такою собі точкою перетину різних напрямків наукових думок.

Як вважає В. І. Шаховський, вивчення почуттів у галузі лінгвістики, вийшло на новий рівень. Також вчений стверджує, що російські лінгвісти відрізняються від французьких тим, що французи дотримувалися думки, що емоційне забарвлення можуть мати не всі слова, а більшість слів мають нейтральне забарвлення, в той момент коли російські психолінгвістики вважали такий поділ не правильним, і вони переконані, що кожне слово має емоційний компонент [3, с. 13].

Існує два способи вираження емоцій:

- вербальний - Verbal language (мовні засоби);

- невербальний - Body language (жести, міміка тощо).

3 цього випливає, що $є$ дві семіотичні системи емоцій, як мінімум, і вони ще недостатньо вивченні. Невербальний спосіб вираження емоцій програє вербальному, так як завдяки вербальному способу ми можемо швидше, надійніше та прямо спілкуватися 3 іншою особою.

Однією з головних причин важливості емоцій у лінгвістиці $\epsilon$ наука емотиологія. Емотиологія - це дисципліна, яка досліджує вираження, вербалізацію та еквівалент емоцій. Отже, можна дійти висновку, що емоційне самовираження майже завжди пов'язане з мовою. Це через те, що мова - знакова система, яка система складається 3 мовних явищ, також вона $€$ неоднорідною за своєю структурою.

Емоційний стан людини не може бути виражений мовними засобами конкретно. У лінгвістиці ми маємо два терміни, які використовуються паралельно «емотивність» та «емоційність». Перший термін відноситься до базового опису мови в загальному та художньому тексті, зокрема В. І. Шаховський бачить різницю цих термінів у тому, що на мовному рівні емоційність як психологічна категорія перетворюється в емотивну. В процесі дослідження емотивності як певну категорію художнього тексту всім важливо враховувати специфіку семантики, а саме текстової, а 
також не слід упускати і людські емоції. Найважливішими властивостями людини є іiі суб'єктивність та предметність.

Емотивність та емоції взаємопов'язані між собою дуже тісно, так як емотивність відображається у емоціях. Існує два погляди: перший заключається в тому, що мова проникнута інтелектуальними аспектами, а емоції знаходяться на другому місці, в той момент як другий погляд показує, що мова підкорена емоційному так само як і інтелектуальне. Емоції можуть трансформуватися в емотивність, через те, що емоції відносяться до емоційної категорії, а емотивність до мовної.

Лексика на позначення емоцій, повністю має відрізнятися від емотивної лексики. Семантика цієї лексики не може містити емоційне вираження, тобто вона позначатиме не почуття, а тільки думку. Отже, емотивна лексика це слова в яких міститься оцінка явищ, а лексика емоцій включає слова, значення котрих можуть складати поняття про емоції. Слова котрі забарвлені емоційно належать до емоційної лексики, таким словам властива чуттєвість.

Емотивність є однією з невід'ємних частин художнього тексту. Існує три складові емотивності: предметність, залученість та сугестивність. Предметність - це присутність у тексті емоційних знань (емоціогенних). Залученість - це втілення намірів автора, а саме емоційних, у певному тексті. Сугестивність - це деякі вказівки читачу на емоційне реагування на текст.

Безліч дослідників працювали над темою емотивності. Найбільш ретельно досліджуванням емотивності займався В. І. Шаховський. За В. І. Шаховським можна дійти висновку, що емотивність - це мовні засоби, котрі виражені емоційністю, вираження засобами (мовленнєвими) тих самих почуттів, переживань та настрою людини. Схожу думку висловлює вчений І. М. Літвінчук: «результат інтелектуальної інтерпретації емоційності, що транслюється в мові та мовленні» [10, с. 96].

Проблема емотивності є однією з найбільших у розвитку лінгвістичної парадигми. Головною засадою цієї парадигми є велика увага концентрації уваги на людині, котра користується мовою. «Поняття «емотивності» $е$ когнітивним чи мовним?» одна 3 проблем, яку дослідники не можуть вирішити. Різні праці дають нам різні варіанти, читаючи різну інформацію постають все нові питання. Через те що поняття емотивності $€$ мало дослідженим його часто вважають за оцінку та експресивність.

Існує таке поняття як «емотив». Цей мовний термін ввів В. І. Шаховський; він вважає, що функція цього терміну полягає у вираженні емоції. Окрім поняття «емотив» В. І. Шаховський ввів ще один термін «емосеми». За його словами емосеми це окремий вид сем, які залежать від емоцій тієї людини, яка говорить. Емоційне вираження $є$ основною функцією емотивів, але на жаль класифікацію емотивів ще не розроблено, так як цією темою до сьогодні ніхто глобально не займався.

Емотивний компонент значення слова $є$ результатом відображення емоцій в слові в процесі їх вербалізації та семантизації. Коли емотивний компонент $є$ соціально узагальнений, він може служити для індивідуального вираження емоційної оцінності об'єктів світу, його реалізація відбувається в емоційних ситуаціях спілкування через емоційний тип мовленнєвих актів. Все це дозволяє нам говорити про винятковий та емоційний тип комунікації.

Емотивність лексики є явищем, яке є різностороннім. Емотивність може полягати «в семантичній інтерпретації емоцій». Комунікативні наміри, які є втілюваними в емотивному дискурсі $є$ різноманітними. А відрізняються вони залежно від характеру та обставин дискурсу. У своїй комунікації людині притаманно використовувати невеликий обсяг емотивної лексики, яка адаптована для того щоб втілювати різні задуми. Поняттям емотивної лексики першим зацікавився В. І. Шаховський, цій темі він посвятив свою роботу, котра має назву «Категоризация эмоций в лексикосемантической системе (1988)». Емотивну лексику він пояснює, як лексику, яка завжди існує з явною, всім відомою емотивністю, які можна розпізнати в контексті і без контексту.

Отже, можна зробити висновок, що кожна культура та мікрокультура має різне ставлення до емоцій та може надавати їм конкретну соціальну конотацію, це не може не вплинути на систему уявлень якогось народу про соціальну організацію та світ і представлення мовних елементів для позначення емоційної лексики в 
мові. Хоча емотивність та емоційність вивчають давно, ця тема $\epsilon$ ще актуальною в сучасному світі і ніхто не може дійти одного висновку.

Мова є основою людського спілкування, вона забезпечує не тільки обміном інформацією, але й відображає певні емоції, тобто емоційний стан людини яка розмовляє. Більшість дослідників поділяють емоції на позитивні та негативні і вони вважають, що є безліч емоцій які відносяться до однієї групи і до іншої. Дослідник М. Аргайло, також вважає, що є різноманітні негативні емоції (депресія, страх, гнів тощо) і тільки одна позитивна, і цією позитивною емоцією $є-$ радість. За словами К. Ізарда радість це позитивна емоція, яка пов'язана з можливістю задовольнити потребу. Радість можна розглядати як одну з форм вираження емоційного стану, дослідники, а саме Шаховський В.І. дослідив, що радість є кластерною емоцією, тобто це та яка має безліч собі подібних емоцій, вона є базовою [7, с. 439]. Інші емоційні стани є похідними від радості і можуть розрізнятися за ступенем інтенсивності. Найчастіше між собою плутають щастя і радість, хоча Е. Фромм вирішив це питання. Радість це переживання якогось тимчасової події, в той момент коли щастя - це постійне переживання радості. Причина через яку часто ототожнюють радість та щастя $є$ те що під час цих емоційних станів люди найчастіше впевнені в собі, у всіх своїх діях і це дає ій певний спокій $[11$, с. 10$]$.

Як дослідили відомі учені стан радості можна виразити, описати та назвати. Якщо ми називаємо радість, то ми використовуємо тільки нейтральні слова і вони передають лише певну дефініцію про радість. Наприклад, такі лексеми, як satisfaction (задоволення), jоy (радість), optimism (оптимізм), а також слова протилежні їм за значенням, тобто синоніми.

В. I. Шаховський зазначає, щоб описати радість ми можемо використовувати кононативи, а для вираження цього емоційного стану - афективи. До конотативів додається емотивна семантика, в той час як в афективах цей компонент не присутній. Коли персонаж сам описує свої емоції, що він відчуває, у цьому випадку радість передається від першої особи, тобто це тоді коли персо- наж сам розказує та описує свій емоційний стан або ж словами автора. Але в обох випадках лексика позначається однією спеціальною лексикою, і вона передає цей стан. Ця лексика включає в себе усі самостійні частини англійської мови.

Відомий дослідник О. М. Вольф вважав, що існує дві мови мова вираження емоцій, а також мова опису тих самих емоцій. Це пояснюється тим, що в лінгвістиці існують різні шляхи дослідження емоцій. Тобто думка полягає в тому, що емотивна лексика, відрізняється від лексики, яка позначає емоції. Семантика такої лексики немає очевидного вираження емоційного ставлення, тому можна дійти висновку, що вона позначає не самі почуття, а тільки логічну думку про них самих. Лінгвісти вважають емотивною лексикою ті слова, в яких міститься якась певна оцінка явищ, які вони позначають, а сама лексика емоцій включає в себе слова, в яких предметно-логічне значення створюють поняття про якісь певні емоції. Відомі дослідники відносять до емоційної лексики тільки слова, яким властива чуттєвість, тобто емоційно забарвлені.

Найбільш широко в категорії емотивності проводив дослідження відомий дослідник I. I. Квасюк, найглибше він досліджував негативну емотивність, тому виділяє два класи емотивної лексики:

- слова, котрі називають різні емоційні стани людини;

- слова, з семантикою, яка може характеризуватися наявністю емотивного компонента.

Також I. I. Квасюк, вважав, що лексика, а саме емоційна, може включати в себе групу слів котрі:

- можуть називати почуття та емоції людини;

- описують різноманітні прояви почуттів та емоцій людини, в більшості випадків це слова, які описують особливості поведінки людини в якомусь конкретному емоційному стані;

- група слів котрі можуть набувати емотивного забарвлення у певному контексті.

Можна дійти висновку, що у словнику кожної мови містяться не тільки слова з сильним стилістичним забарвленням, який до- 
зволяє виражати емоції, а також слова, які в контексті викликають певне емоційне забарвлення.

\section{Література:}

1. Гарбовский Н. К. Теория перевода. - Москва: Изд-во Моск. Унта. $-2007 .-544$ c.

2. Маслова В. А. Лінгвістичний аналіз експресивності художнього тексту / В. А. Маслова. - Минск: Вишейшая школа, 1997. - 183 с.

3. Кубрякова Е. С. Типы языковых значений. Семантика производного слова. - Москва: ЛКИ, 2007. - 208 с.

4. Червоних В. В. Етнопсихолінгвістика та лінгвокультурології: Курс лекцій. - М.: ІТДГК Гнозис, 2002. - 284 с.

5. Адамчук Т. В. Тематизация эмоций в тексте (на материале современного английского языка): автореф. дис. канд. филол. наук: 10.02.04 / Адамчук Т. В. - Саранск: Мордовский гос. пед. институт. - 1996. $15 \mathrm{c}$.

6. Арнольд И. В. Стилистика современного английского языка. Москва: Просвещение, 1990. - С. 83-87.

7. Хван Н. А. Когнитивно-прагматические и эмотивно- экспрессивные свойства междометных единиц в художественном тексте (на материале английского языка): - Дисс. канд. филол. наук. - Тула, 2005. $-215 \mathrm{c}$.

8. Шаховский В. И. О лингвистике эмоций / В. И. Шаховский // Язык и эмоции: сб. научн. тр. / Под ред. В. И. Шаховского и др. - Волгоград: Перемена, 1995. - С. 3-15.

\section{Трофименко Анастасія}

(м. Кам'янеиь-Подільский, Украӥна)

Кам'янець-Подільський наџіональний університет ім. Івана Огієнка

\section{РОЗВИТОК МІЖКУЛЬТУРНОЇ КОМУНІКАТИВНОЇ КОМПЕТЕНЦІЇ В КОНТЕКСТІ ГЛОБАЛІЗАЦЇ̈}

У тезах розглянуто процес розвитку іншомовної професійної комунікативної компетентності студентів з урахуванням специфіки освітніх рівнів в безперервній багаторівневіи структурі курсу дисципліни «Іноземна для спеціальних (професійних) иілей» на основі застосування нових інформаційних технологій, проаналізовано результати роботи щяодо вдосконалення рівня сформованості іншомовної професійної комунікативної компетентності студентів немовного вузу.

Ключові слова: комунікативна компетенція, іноземна мова, міжкультурна комунікація

В тезисах рассмотрен проиесс развития иноязычнои профессиональной коммуникативной компетентности студентов с учетом специффики образовательных уровней в непрерывной многоуровневой структуре курса дисииплинь «Иностранный для спечиальных (профессиональных) иелей» на основе применения новых информаџионных технологий, проанализированы результаты работы по усовершенствованию уровня сформированности иноязычной профессиональной коммуникативной компетентности студентов неязыкового вуза.

Ключевые слова: коммуникативная компетенция, иностранный язык, межкультурная коммуникация.

The process of development of students' intercultural professional communicative competence is envisaged, taking into account the specificity of educational levels in the continuous multilevel structure of the course "English for specific (professional) purposes» on the basis of application of new information technologies, the results of work on improving the level of formation of 
students' intercultural professional communicative competence in tertiary education are analyzed.

Key words: communicative competence, foreign language, intercultural communication.

Дані напрями модернізації української освіти актуалізують формування і розвиток міжкультурної комунікативної компетентності як важливого чинника підвищення якості професійної підготовки студентів будь-якої спеціальності в процесі вивчення дисципліни «Іноземна мова» у вищому навчальному закладі, що $\epsilon$ особливо затребуваним на етапі розвитку нових інформаційних технологій та участі України в міжнародних освітніх проектах.

Міжнародна мобільність студентів і майбутніх випускників виступає не тільки як індикатор їх суб'єктивної активності в освоєнні професії, а й як один із суттєвих показників міжнародної акредитації вузівських програм, істотним чинником зростання престижу вузу, його рейтингу на світовому ринку освітніх послуг. Конкурентоспроможність випускників багато в чому визначає і конкурентоспроможність самих вузів, пред'являючи підвищені вимоги до організації процесу професійно-орієнтованої підготовки студентів, в тому числі і в процесі вивчення іноземної мови.

Під міжнародною мобільністю студентів і випускників вузу ми розуміємо нормативно-правову, соціальну і професійну можливість їх успішної взаємодії, вільного пересування і проживання в полікультурному просторі, професійно-особистісну готовність до соціокультурного та професійно-орієнтованого спілкування 3 фахівцями інших країн, прояву толерантності, емпатії, здатності реалізовувати набір професійних компетенцій в діяльності, бути конкурентноспроможними на ринку праці, успішно встановлювати контакт з носіями мови, не зазнаючи труднощів в процесі комунікації з представниками іншого соціуму, мати доступ до різноманіття світової культури і науки, до отримання професійної освіти, діючи в режимі вторинної мовної особистості.

Дані проблеми, заломлюючись через контекст глобалізації та культурної динаміки, передбачають формування у сучасного ви- пускника вузу здатності орієнтуватися в світовому професійному просторі. Таким чином, міжкультурна комунікація є одним із засобів, що забезпечує досягнення цієї мети. Міжкультурна комунікація - це взаємодія представників різних культур. Розвиток міжкультурної комунікативної компетенції дозволить розуміти погляди, думки, звичаї і традиції представників іншої культури, коригувати свою поведінку, долати конфлікти в процесі комунікації, визнавати право на існування різних цінностей і норм поведінки.

У зв'язку з цим розвиток міжкультурної комунікативної компетенції студентів немовного вузу створює основу для професійної мобільності, підготовки студентів і випускників вищого навчального закладу до швидко мінливих умов життя, залучає майбутніх фахівців до стандартів світових досягнень, збільшує можливості професійної самореалізації на основі комунікативності і толерантності, стає необхідною умовою професійного розвитку сучасного фахівця.

В умовах «інокультурного середовища» в процесі розвитку іншомовної професійної комунікативної компетентності у студента формуються риси вторинної мовної особистості, що роблять його здатним бути ефективним учасником міжкультурної комунікації. Розвиток іншомовної професійної комунікативної компетентності студентів немовного вузу з метою здійснення успішної міжкультурної комунікації і є стратегічною метою навчання іноземної мови. Реалізувати цю мету - значить розвинути у фахівця здатність до спілкування в «параметрах» текстової діяльності Таке розуміння кінцевого результату навчання найприроднішим чином пов'язане $з$ необхідністю не тільки розвивати у студента вміння користуватися відповідною іншомовною «технікою», а й колосальною позамовною інформацією, необхідною для адекватного спілкування і взаєморозуміння на міжкультурному рівні, а також розвивати в ньому такі якості, які дозволять здійснювати безпосереднє і опосередковане спілкування 3 представниками інших культур.

Вивчення дисципліни «Іноземна мова для спеціальних (професійних цілей) - «Language for Specific Purposes» (LSP) - має на 
меті вдосконалення рівня іншомовної професійної комунікативної компетентності, яка розглядається як здатність майбутнього фахівця:

- здійснювати міжкультурне професійно-орієнтоване спілкування в якості вторинної мовної особистості;

- взаємодіяти з носіями іншої культури з урахуванням національних цінностей, норм і уявлень;

- створювати позитивний для комунікантів настрій в спілкуванні;

- вибирати комунікативно доцільні способи вербальної і невербальної поведінки на основі знань про науку і культуру інших народів в рамках полілогу культур;

- зберігати національну самоідентифікацію в умовах міжнародної інтеграції та мобільності [1].

Підвищення якості професійної підготовки студентів шляхом розширення професійного профілю засобами іноземної мови $є$ одним із шляхів підвищення якості вітчизняної освіти на міжнародному ринку праці.

\section{Література:}

1. Андриенко А. С. Развитие иноязычной профессиональной коммуникативной компетентности студентов технического вуза (на основе кредитно-модульной технологии обучения): Дис. .... канд. пед. наук: 13.00.08 / Анжела Сергеевна Андриенко. - Ро-стов н/Д, 2007. - 282 с.

2. Гальскова Н. Д. Современная методика обучения иностранным языкам. - М.: Аркти - Глосса, 2000. - 165 с.

3. Глобализация и конвергенция образования: технологический аспект. Научное издание / Под общей ред. профессора Ю. Б. Рубина. М.: ООО «Маркет DC Корпорейшн», 2004. - 540 с.

4. Евдокимова М. Г. Профессионально ориентированное обучение иностранным языкам в неязыковом вузе как система / М. Г. Евдокимова // Иностранный язык как компонент профессио-нальной подготовки в неязыковом вузе. - М.: Вестник Моск. лингвистич. ун-та. Педагогические науки, 2013. - Вып. 12 (672).

\section{Ціось Ангеліна}

(м. Острог, Украӥна)

Національний університет «Острозька академія»

\section{ГЕНЕАЛОГІЧНЕ ДЕРЕВО ЯК СЮЖЕТОТВОРЧИЙ ЕЛЕМЕНТ У ЦИКЛІ РОМАНІВ «ПІСНЯ ЛЬОДУ ТА ПОЛУМ'Я»} ДЖОРДЖА МАРТІНА

У тезах розглядаються генеалогія та архетипи як головний фрагмент сюжетної композииії романів «Пісня льоду та полум'я» Дж. Мартіна, а також часові паралелі роману.

Ключові слова: архетипи, генеалогія, рід, історія, архетип матері, архетип Божої дитини, архетип батька, петля чacy.

В тезисах рассматриваются генеалогия и архетипь как главньй фрагмент сюжетной композиции романов «Песнь льда и пламени» Дж. Мартина, а также временные параллели романа.

Ключевые слова: архетипь, генеалогия, род, история, архетип матери, архетип Божественного ребенка, архетип отиа, петля времени.

The research deals with genealogy and archetypes as the main part of the plot composition of the cycle of novels «The Song of Ice and Flame» by G. Martin and the temporal parallels of the novel.

Key words: archetypes, genealogy, genus, history, archetype of mother, archetype of God's child, archetype of father, loop of time.

Постановка проблеми. Природно, що людям завжди були цікаві інтриги та перипетії у чужих родинах, тому що вони певним чином мають вплив на історію. Велика кількість письменників зверталась до цієї теми. Звичайно, не міг не охопити цю тему і сам письменник - фантаст Джордж Мартін у своїй епопеї «Пісня Льоду та полум'я». Вдало користуючись архетипами К.

(C) Ціось Ангеліна, 2018 
Юнга при створенні нових персонажів він створює цілу історію у середині свого роману. Генеалогія у творі дає можливість по новому зазирнути в історію та темну тінь людей у ній, зберігаючи безпечну відстань.

Об'єктом дослідження $є$ цикл романів «Пісня льоду та полум'я» Джорджа Мартіна. Предметом дослідження є генеалогічне дерево та архетипи. Мета дослідження: дослідити вплив генеалогії на сюжетну лінію та історію у романі. Актуальність полягає у проблематичності родинних стосунків. Автор пише про речі, що є актуальними в усі часи поки люди кохають, одружуються, народжують дітей. Саме це $є$ основою історії. Теоретичною основою статті $є$ наукові праці Карла Густава Юнга «Червона книга», «Проблеми душі нашого часу» та «Душа і міф». А також, підручник «Теорія літератури» Галича О., Назарець В., Васильєва $€$.

Методи дослідження. Психоаналіз - це психотерапевтичний метод, розроблений 3. Фройдом. Проте, був доповнений i розвинутий Юнгом, який запропонував ідею архетипів і ідею індивідуації(а також покращив методологію досліджень і терапіi). Метод архетипів - це метод, створений Карлом Густавом Юнгом. Архетипи, згідно з Юнгом, є формальними зразками поведінки, або символічними образами, на основі яких оформлюються конкретні, наповнені змістом образи, що відповідають у реальному житті стереотипам свідомої діяльності людини.

Створюючи роман «Пісня льоду та полум'я», Дж. Мартін мав на увазі перш за все версію розвитку свого світу, який він створив, але твір виявився набагато більш значущим, оскільки змалював історію розвитку людства через історію родів, або ж великих будинків Вестеросу, як їх називають у романі.

Вони грають в престоли і ведуть армії в бій, присягають королям або оголошують королями себе, клянуться у вірності і зраджують, проявляють неймовірну хоробрість і благородство або вражають підлістю і віроломством. Вони - лорди Вестеросу, світу, створеного Джорджем Мартіном.

Великі будинки - це вища знать континенту Вестерос, де відбувається основна частина подій «Пісні льоду і полум'я» Джор- джа Мартіна. Це навіть не сім’ї, а цілі клани, від яких залежала, залежить i, швидше за все, буде залежати все життя Семи Королівств. Кожен з будинків має багату і незвичайною історією, а також відмінні риси, які ретельно пропрацював Мартін.

Як ми бачимо, історія родини Таргарієнів, Старків і Ланністерів - це історія становлення людського суспільства: від патріархального укладу, де вагому роль зіграє жінка, до громадянської війни.

Історія схожа з багатьма іншими. Так в розвитку подій роману можна побачити історію майже біблійну: кровозмішення, вбивство, новий світ, відкриття законів природи і підкорення iï,економічний розвиток, війни і революції, а потім усвідомлення думки про наближення кінця. Але все це так само показано через історію роду, який дав початок цілому народові.

Так ось Мартін в романі відтворює історію людства через історію народу і роду, щоб зрозуміти долю світу, великі закони його існування та психологію людей. Намагаючись розібратися у цьому автор при написані творів спирається на учення Карла Густава Юнга про колективне несвідоме.

Архетип у літературознавстві - це реконструйована фабула або сюжет, загальні для міфів, фольклору та літератури різних народів. Тобто, якщо персонаж відноситься до того чи іншого архетипу, він буде здаватись дуже знайомим [1].

На думку Юнга, в кожній індивідуальній структурі мозку заховано велике, духовну спадщину - колективне несвідоме. У порівнянні $з$ ним, свідомість - явище ефемерне, його завдання здійснювати лише миттєву орієнтацію, пристосування до навколишнього світу. Згідно К.Г. Юнгом, несвідоме являє собою неозорий резервуар нашого «Я», який пов’ язує свідомість (невелику і змістовно бідну область психіки, що знаходиться під нашим контролем) зі сферою інстинктивного життя [5].

Дж. Мартін недаремно використовує відразу декілька архетипів, протиставляючи їх один одному. Таким чином, він проектує гостросюжетні лінії, які захоплюють читача. Створюючи цілу історію у романі, Мартін не зміг обійтися без трьох найважливіших постатей, а саме матері, батька і дитини. 
Діяльність цих архетипів ми можемо бачити навіть в той час, коли, здавалося б, панує раціоналізм - так, відповідно до християнської догми, Бог-Отець, Бог-Син і Бог-Святий Дух утворюють Трійцю. Дослідник відзначає, що Святий Дух зображується у вигляді птаха Астарти - голуба. В епоху раннього християнства цю птицю іменували Софією, і вона уособлювала жіноче начало. Сучасне християнство давно відмовилося від подібного трактування Святого Духа; проте заміною образу жінки-птиці є образ Марії. Таким чином, стверджує К.Г. Юнг, перед нами класичний архетип сім'ї «на небесах» [6, с. 334].

Найпотужнішим і найсильнішим образом роману є архетипний образ Матері. Не потрібно бути психологом, щоб зрозуміти, що саме він один з ключових образів для кожного читача, нехай навіть не найвагоміший для всього сценарію.

До архетипу матері, належать три героїні Серсея Ланністер, Кейтелін Старк та Дейенеріс Таргарієн. Здається кожна з них, може бути матір'ю великого народу і розпочати новий етап істоpiï. Проте, у народу, як і у дитини, не може бути дві чи три матері. Двоє з них мають загинути.

Спершу, розглянемо архетипний образ Серсеї Ланністер. Це - Королева Семи Королівств Вестеросу. Видана заміж за нелюба короля Роберта Баратеона, яка народила трьох дітей. Здавалося б, жінка, приречена стати, з властивою покорою, мовчазною тінню чоловіка-короля так чи інакше стає ключовою фігурою у романі. Серсеї можна співчувати, ставитися з розумінням, боятися або ненавидіти. Її персонаж - сукупність, здавалося б, абсолютно несумісних якостей: жінка хитра, схильна до маніпуляцій, безжальна до ворогів, полум'яна коханка, i захисниця своїх дітей. Безумовно, до Серсеї можна мати симпатію, і вважати прикладом для наслідування. Незважаючи на свою видиму крихкість і беззахисність, ця жінка $з$ самого раннього дитинства знає, що таке влада і як її використовувати. Для неї не існує перешкод і кордонів, а мораль і традиції - порожній звук.

Також, Серсея переживає інцест. Справа в тому, що понад усе для однієї з головних негативних героїнь цінності сім'ї і влади, а інцест у неї включений в цінності сім’ї [7].
Вона вважає, що близька кровна спорідненість один з чинників прогресу. I тут, ми можемо прослідкувати сюжет «навпаки» до твору Габріеля Маркеса «Сто років самотності», де близька кровна спорідненість веде до регресу. Не варто випускати з уваги, що і батько Серсеї Тайвін був одружений зі своєю кузиною. Після загибелі дітей для Серсеї стає актуальною цінність помсти, але з раптовою вагітністю вона відходить на другий план.

За своєю суттю, Серсея - образ психопатичного особистості, яка живить щирі почуття, здавалося б, тільки до своїх дітей. Серсея соціопат - вона не підпускає до своїх емоцій, здається, нікого. Незважаючи на це, вона категорична і не терпить програшу. Ї̈̈ психіка - стійка до всього, навіть до втрати близьких. Гуманність і людяність їй також, не властиві. Вона, безумовно - гедоніст [7].

Всі ці якості, характеризують Серсею як агресивного хижака. Протистоїть їй - образ Матері, втілений в ролі Кейтелін Старк. Мати півночі, голова роду Старків. Полум'яно любить свого чоловіка, i, завдяки своєму походженню, стає шанованою персоною в дипломатії і правлінні північчю континенту. У них з Недом Старком - четверо дітей, плюс, народжений поза шлюбом Джон Сноу, якого вона прийняла, нехай і відверто зневажаючи його як плід зради свого улюбленого чоловіка. Туди ж, можна додати вихованого Старками в'язня-принца Теона Грейджоя, до якого Кейтелін ставилася тепліше, ніж до Джона.

Кейтелін емоційна і щира. Вона любляча, але сувора мати, свято прихильна до традицій родини і шлюбу. Вона, здавалося б, готова піти на брехню, щоб зберегти щастя сім'ї, але навіть ця авантюра, вдається ій важко. Вона готова постояти за себе, і битися за життя своїх дітей і близьких. Їй властива чутливість до совісті і високий ступінь відповідальності.

Образ Леді Старк як архетипу матері, найбільш чітко видно у романі. Особливо, це видно у сюжетній лінії Кейтелін, що триває після іiі смерті. Це образ матері-привида, а саме Кам'яна Леді, який супроводжує живих дітей Старків. В протиставленні з Серсеєю, Кейтелін, швидше за все невинна, але люта тварина, особливо коли мова заходить про захист молодшого покоління. Вона 
чуйно шанує традиції «зграї» і племені, і не суперечить «ватажкові». Напевно, недаремно, гербом Старків є Вовк.

Інша героїня, Дейенеріс Таргарієн, втілює архетип матері. Вона матір драконів, матів визволених рабів, проте мати не може бути без своїх рідних дітей. Тому, вона ділить свою нерозділену любов 3 народом. Кращого образу для матері народу і зміни історії не знайти [3].

Дейнеріс $є$ жіночим втіленням свого пращура Ейгона I Таргарієна, який разом зі своїми сестрами-дружинами Рейніс і Весенією засновує династію великих королів і створює трьох драконів. Знову ж таки, прослідковується сюжет «навпаки» до твору Габріеля Маркеса «Сто років самотності». Близька кровна спорідненість, яка веде до прогресу.

Наступний образ, який прослідковується у романі, це архетип Божої дитини. У романі мотив Божої дитини втілює Джон Сноу. Цей мотив супроводжує сюжетну лінію героя з моменту появи у романі. Лише в останньому томі роману читач нарешті з'ясовує таємницю народження героя. У Джона Сноу мотив Божої дитини тісно пов'язаний з мотивом героя. У якийсь момент він перестає бути дитиною і стає героєм. Відбувається це через мотив служіння. Сноу йде служити у нічну варту і переходить в архетип героя.

Боже дитя долає перешкоди, але врешті-решт його щось губить, найчастіше зрада. Так і Сноу гине через зраду, але потім воскресає. На думку психолога Ольги Гаврилової, тут можна побачити паралелі з Ісусом Христом і Гераклом, яких Юнг вважав Божими дітьми. Якщо Божа дитина воскресла, вона не може вдруге померти, тому за життя Джона Сноу можна не побоюватися [3].

Або може все-таки варто побоюватися? Коли Джон дізнається таємницю свого народження, він знаходить свою самость, тому тепер з ним, на жаль, може трапитися що завгодно.

I наступний образ, це архетип батька. Архетип батька має безліч імен: керівник, король, вождь, капітан, генерал, президент. Всі вони, за великим рахунком, несуть батьківську відповідальність за тих, хто їм підкоряється. Батько має бути і добрим, i жорстоким водночас, а головне він має бути справедливим. Найкра- щим прикладом архетипа батька був Нед Старк. Він навіть віддав життя за своїх дітей.

Йому протистоїть, образ батька у ролі Тайвіна Ланністера. Так, як не дивно, але він завжди ніс відповідальність за своїх дітей. Виховуючи їх без дружини, він дав їм належну освіту і виховання. Більш того, він ніс відповідальність не тільки за своїх дітей, а також за свій народ, тому що він був Десницею короля.

Таким чинном, ми бачимо, що герої роману це творці історії. Вони утворюють петлю часу. Повторюють долю їхніх пращурів: громадянські війни, близьку кровну спорідненість, сутички та конфлікти, релігійні баталії, кохання та ненависть. Автор ніби доносить нам, що історія повторюється, і все, що вже було, ще буде!

Роман Дж. Мартіна об'єднує у собі фантастику і дійсність, прозаїчність тону, фантазію і гротеск, які відображають саму історію людства. Так вивчивши генеалогію та історію у романі, нам вдалося побачити історію майже біблійну: кровозмішення, вбивство, новий світ, відкриття законів природи і підкорення іiі, економічний розвиток, війни і революції, а потім усвідомлення думки про наближення кінця. Саме це хотів донести автор, сюжет роману - це історія, яка буде повторюватись і ще не раз, i не тільки в творах письменників, а й у реальності.

\section{Література:}

1. Галич О., Назарець В., Васильєв Є. Теорія літератури / О. Галич, В. Назарець, Є. Васильєв. - Київ: Либідь, 2005. - 460 с.

2. Юнг, К. Г. Червона книга / К. Г. Юнг [Електронний ресурс]. - Pежим доступу: https://www.e-reading.club/book.php?book=1020693

3. Гаврилова Ольга. Архетип Божественного ребенка в сериале «Игра престолов» / О. Гаврилова [Електронний ресурс]. - Режим доступу: https://www.youtube.com/watch?v=aEsX9IeHIKo

4. Мартин Дж. Р. Р. Битва королей /Дж. Р. Р. Мартин [Електронний pecypc]. - Режим доступу: http:// knijky.ru/books/bitva-koroley

5. Юнг, К. Г. Душа и миф / К. Г. Юнг - Киев: Государственная библиотека Украины для юношества, 1996 - 384 с.

6. Юнг, К. Г. Проблемы души нашего времени / К. Г. Юнг - СанктПетербург: Питер, «Мастера психологии», 2017. - 336 с. 
7. Яблонская Светлана. Когда солнце встанет на западе и опустится на востоке: травма и ее преодоление в мире «Игры престолов» / C. Яблонская [Електронний ресурс]. - Режим доступу: https://www. youtube.com/watch?v=O7QUQBByHtM

8. Martin G. R. R. A Clash of Kings/ G. R. R. Martin. - NY.: Bantam Books 1999. -813 p.

\section{ВІДОМОСТІ ПРО АВТОРІВ}

Блоха Мирослава - студентка факультету романо-германських мов Національного університету «Острозька академія»

Бобер Анастасія - студентка інституту іноземної філології Житомирського державного університету імені Івана Франка

Бобков Вадим - викладач кафедри міжнародної мовної комунікації Національного університету «Острозька академія»

Божченко Владислав - студент факультету романо-германських мов Національного університету «Острозька академія»

Брожик Ольга - студентка факультету романо-германських мов Національного університету «Острозька академія»

Войціховський Ілля - студент факультету романо-германських мов Національного університету «Острозька академія»

Воробей Віталій - студент факультету романо-германських мов Національного університету «Острозька академія»

Гаталяк Марта - студентка факультету романо-германських мов Національного університету «Острозька академія»

Герасимчук Валентина - студентка факультету романо-германських мов Національного університету «Острозька академія»

Іванішина Наталія - студентка факультету романо-германських мов Національного університету «Острозька академія»

Іванова Ольга - студентка факультету романо-германських мов Національного університету «Острозька академія»

Кобильчук Вадим - студент факультету романо-германських мов Національного університету «Острозька академія»

Козловська Ольга - студентка факультету романо-германських мов Національного університету «Острозька академія»

Крайчинська Галина - кандидат філологічних наук, доцент, завідувач кафедри міжнародної мовної комунікації Національного університету «Острозька академія»

Курілович Ольга - студентка факультету романо-германських мов Національного університету «Острозька академія» 
Максимчук Ірина - студентка факультету романо-германських мов Національного університету «Острозька академія»

Мельник Анна - студентка факультету романо-германських мов Національного університету «Острозька академія»

Мирончук Ірина - студентка факультету романо-германських мов Національного університету «Острозька академія»

Місюк Ярослав - студент факультету романо-германських мов Національного університету «Острозька академія»

Новікова Ірина - студентка факультету романо-германських мов Національного університету «Острозька академія»

Новоселецька Світлана - кандидат психологічних наук, доцент кафедри англійської мови та літератури Національного університету «Острозька академія»

Радчук Олена - студентка факультету романо-германських мов Національного університету «Острозька академія»

Савіцька Аліна - студентка факультету романо-германських мов Національного університету «Острозька академія»

Соломчук Ольга - студентка факультету романо-германських мов Національного університету «Острозька академія»

Тилько Анастасія - студентка факультету романо-германських мов Національного університету «Острозька академія»

Трофименко Анастасія - кандидат педагогічних наук, доцент кафедри іноземних мов Кам'янець-Подільського університету імені Івана Огієнка

Ціось Ангеліна - студентка факультету романо-германських мов Національного університету «Острозька академія»

Шапран Наталія - кандидат філологічних наук, старший викладач кафедри англійської мови та літератури Національного університету «Острозька академія» 
Наукове видання

\title{
ENGLISH FOR SPECIFIC PURPOSES
}

Збірник наукових тез

Випуск 5

\author{
Укладач Крайчинська Г. В. \\ Технічний редактор Свинарчук $P . B$. \\ Комп'ютерна верстка Крушинської Н. $O$. \\ Художнє оформлення обкладинки Олексійчук $K$. $O$.
}

Формат 60х84/16. Ум. друк. арк. 9,76. Наклад 50 прим. Зам. № 47-18. Папір офсетний. Друк цифровий. Гарнітура «TimesNewRoman».

Оригінал-макет виготовлено у видавництві Національного університету «Острозька академія», Україна, 35800, Рівненська обл., м. Острог, вул. Семінарська, 2. Свідоцтво суб'єкта видавничої справи РВ № 1 від 8 серпня 2000 року.

Видавець СПД Свинарчук Р. В.

Свідоцтво суб'єкта видавничої справи РВ № 27 від 29 липня 2004 року. Тел. (+38067) 77128 70, e-mail: 35800@ukr.net. 